This is the final peer-reviewed accepted manuscript of

Bingen, Bernard; Viola, Giulio: The early-Sveconorwegian orogeny in southern Norway: tectonic model involving delamination of the sub-continental lithospheric mantle. PRECAMBRIAN RESEARCH, 313. 03019268

DOI: 10.1016/j.precamres.2018.05.025

The final published version is available online at:

http://dx.doi.org/10.1016/j.precamres.2018.05.025

Rights / License:

The terms and conditions for the reuse of this version of the manuscript are specified in the publishing policy. For all terms of use and more information see the publisher's website.

This item was downloaded from IRIS Università di Bologna (https://cris.unibo.it/)

When citing, please refer to the published version. 


\title{
The early-Sveconorwegian orogeny in southern Norway: Tectonic model involving delamination of the sub-continental lithospheric mantle
}

\author{
Bernard Bingen $^{\mathrm{a}, *}$, Giulio Viola ${ }^{\mathrm{b}}$ \\ ${ }^{a}$ Geological Survey of Norway, 7491 Trondheim, Norway \\ b Department of Biological, Geological and Environmental Sciences, BiGeA, University of Bologna, 40126 Bologna, Italy
}

Keywords:

Mesoproterozoic Rodinia Lithosphere delamination

Sveconorwegian

Fennoscandia

\begin{abstract}
The Sveconorwegian orogeny is a more than 250 Myr-long multiphase orogenic event that contributed to the amalgamation of Fennoscandia into Rodinia at the end of the Mesoproterozoic. We propose a new lithosphericscale tectonic model for the pre- to early Sveconorwegian orogenic evolution between 1280 and 1080 Ma. This evolution is recorded in southern Norway by two c. $25 \mathrm{~km}$ wide belts of up to granulite-facies rocks, the Bamble and Kongsberg Lithotectonic Units, and a c. $80 \mathrm{~km}$ belt in the Telemarkia Lithotectonic Unit, which contains lower-grade rocks and evidence of widespread plutonism. New zircon U-Pb geochronological data from 54 samples confirm magmatic activity between 1575 and $1485 \mathrm{Ma}$, and 1210 and $1140 \mathrm{Ma}$. The new data constrain peak amphibolite to granulite-facies metamorphism in Bamble and Kongsberg to between 1145 and $1130 \mathrm{Ma}$. New geological mapping shows that the Kongsberg Lithotectonic Unit is characterized by a regional, N-S trending highly transposed lithological banding reflecting E-W orthogonal shortening as expressed by tight to isoclinal folds, and a penetrative subvertical foliation bearing a steep peak-metamorphic lineation. Telemarkia is instead characterized by crustal extension-related bimodal magmatism and intermontane basin sedimentation between 1280 and $1080 \mathrm{Ma}$. Paired and in part coeval extension and compression are interpreted as reflecting asthenospheric upwelling, orogenic plateau development and delamination of the sub-continental lithospheric mantle beneath Telemarkia, followed by foundering (dripping-off) of the lithospheric mantle slab under the Kongsberg and Bamble Lithotectonic Units. This model stresses the pull effect of a foundering mantle slab in an actively shortening orogen to facilitate highly localised compression and granulite-facies metamorphism in the crust. It accounts for the well-known, first-order geological characteristics of the orogen and does not require the accretion of exotic terranes to explain the early-Sveconorwegian orogenic evolution.
\end{abstract}

\section{Introduction}

Late Mesoproterozoic orogenic belts are classically interpreted as the welding orogenic zones between continents to assemble super continent Rodinia at the end of the Mesoproterozoic (Hoffman, 1991; Li et al., 2008). The archetypal and largest amongst them is the $700 \mathrm{~km}$ wide and $>2000 \mathrm{~km}$ long Grenville orogen of Laurentia (Davidson, 2008; Gower et al., 2008; Hynes and Rivers, 2010; Rivers, 2008), which is described as the product of a large, hot and long lived multistage collisional orogeny (Jamieson et al., 2007; Rivers, 2009). Several oro genic phases are recorded spanning 250 Myr from 1245 to 980 Ma (Indares and Dunning, 2004; Rivers, 2008; Rivers, 2009). The main collision event, which took place after c. $1090 \mathrm{Ma}$, reworked the early orogen and widened it towards the foreland (see sketches in, Carr et al., 2000; Cawood et al., 2013; Hynes and Rivers, 2010). Several aspects of the tectonic evolution of the early Grenvillian orogenic phases remain conceptually challenging. The Shawinigan phase, for example, en compasses a 50 Myr long (1190 $1140 \mathrm{Ma}$ ) geological record of compression, extension, sedimentation, granulite facies metamorphism and anorthosite magmatism, which is difficult to explain simply by pre collision accretion. This complex record has given rise to many contrasting tectonic models for the transition towards the main Grenvillian orogenic phases (Carr et al., 2000; Corrigan and Hanmer, 1997; Corriveau and van Breemen, 2000; Hynes and Rivers, 2010; Martignole et al., 2000; Rivers, 2008; Wodicka et al., 2000).

Here, we address the tectonic significance of early orogenic phases in the late Mesoproterozoic Sveconorwegian Orogenic Belt of Fennoscandia (Fig. 1). The Sveconorwegian Orogenic Belt shows an orogenic architecture comparable to the one of the Grenville orogen (Bogdanova et al., 2008; Rivers, 2008) and a similarly long and multiphase orogenic evolution (Bingen et al., 2008a,c). In most Rodinia reconstructions, the Sveconorwegian Orogenic Belt is chained to the

\footnotetext{
* Corresponding author.

E-mail addresses: bernard.bingen@ngu.no (B. Bingen), giulio.viola3@unibo.it (G. Viola).
} 


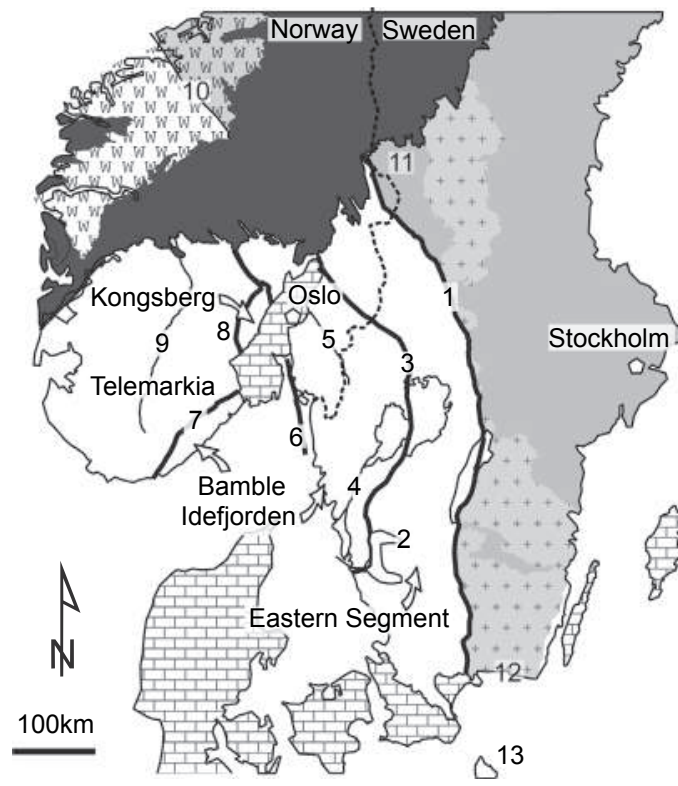

1: Sveconorwegian Front

2: Eclogite-bearing nappe

3: Mylonite Zone

4: Göta-Älv Shear Zone

5: Ørje Shear Zone

6: Østfold-Marstrand Boundary Zone

7: Kristiansand-Porsgrunn Shear Zone 8:

Saggrenda-Sokna Shear Zone

9: Mandal-Ustaoset Fault \& Shear Zone 10:

Northern boundary of Sveconorwegian overprint in

the Western Gneiss Region

11: Dala sandstone

12: Karlshamn granite plutons

13: Bornholm

Thanerozoic

Caledonian nappes

Western Gneiss Region

Sveconorwegian Orogenic Belt

Transcandinavian Igneous Belt in

foreland of Sveconorwegian

Orogenic Belt

Foreland of Sveconorwegian Orogenic Belt

Fig. 1. Sketch map showing the five Lithotectonic Units of the Sveconorwegian Orogenic Belt, and important shear zones, based on Koistinen et al. (2001).

right (east) of the Grenville orogen, facing Amazonia and therefore would result from the collision between proto Baltica and Amazonia (Cawood and Pisarevsky, 2017; Gower et al., 2008; Hoffman, 1991; Ibanez Mejia et al., 2011; Johansson, 2009; Pisarevsky et al., 2014; Tohver et al., 2004; Weber et al., 2010). Non collisional, accretionary only, models (Slagstad et al., 2017; Slagstad et al., 2013) and models with "inverted" Baltica (Hartz and Torsvik, 2002), have also been proposed.

Irrespective of the large scale model, the dynamics of the early orogenic evolution within the 12801080 Ma interval remains poorly understood. We present new geological and geochronological data from the Kongsberg and Bamble Lithotectonic Units of southern Norway, two narrow belts known to host early Sveconorwegian high grade metamorphism (Bingen et al., 2008b; Knudsen et al., 1997; Nijland et al., 2014). Zircon $\mathrm{U} \mathrm{Pb}$ geochronological data are reported from 54 sam ples to constrain the geochronology of magmatic and metamorphic events therein. New observations and results document a reliable geo dynamic framework, which we interpret as characterized by coeval extension and compression in adjacent lithotectonic units. We propose a new lithospheric tectonic model that accounts for the new data and for the existing knowledge. It involves asthenosphere upwelling be neath crustal segments in extension, and foundering (dripping off) of the subcontinental lithospheric mantle beneath adjacent narrow crustal segments in compression. Pioneering studies (Bird, 1979; Dewey, 1988; England and Houseman, 1989) have already established the link between the gravitational instability of the lithospheric mantle keels, extensional tectonics and orogenic plateau buildup in the core of collisional orogens. The model proposed here additionally stresses the pull effect of the foundering mantle slab (Göğüş and Pysklywec, 2008) to generate coexisting compression and granulite facies metamorphism in the crust of a Precambrian orogenic belt.

\section{The Sveconorwegian Orogenic Belt}

The Sveconorwegian Orogenic Belt consists of Paleoproterozoic to Mesoproterozoic continental lithosphere reworked at the Meso to Neoproterozoic boundary at the margin of Fennoscandia (Fig. 1) (Berthelsen, 1980; Demaiffe and Michot, 1985; Falkum, 1985). The northern part of the orogen was reworked during the Paleozoic Cale donian orogeny while the southern part is near pristine. The latter is c. $550 \mathrm{~km}$ wide, has a general N S structural grain and in the east abuts the essentially Sveconorwegian strain free foreland along the nearly 700 km long Sveconorwegian Front (Fig. 1) (Wahlgren et al., 1994). The orogen can be conceptually subdivided into five, orogen parallel Lithotectonic Units (INSPIRE Directive, 2007), called, from east to west, the Eastern Segment, Idefjorden, Kongsberg, Bamble, and Tele markia Lithotectonic Units (hereinafter referred to as Unit in short)(Bingen et al., 2008c). These lithotectonic units have distinct pre Sve conorwegian and Sveconorwegian histories, and are separated by major Sveconorwegian shear zones. Alternative nomenclatures for the main units are also proposed in the literature (Slagstad et al., 2017).

The Sveconorwegian orogeny ensued from a period of within plate magmatism between 1350 and 1140 Ma (references below). The first high grade metamorphic event associated with convergent tectonics is recorded in the Bamble and Kongsberg Units between 1145 and 1130 Ma. This early Sveconorwegian orogenic phase was named the Arendal phase by Bingen et al. (2008a,c). The later orogenic evolution is well summarized by three distinct orogenic phases (Bingen et al., 2008a,c), the main Sveconorwegian Agder phase (1050 $980 \mathrm{Ma}$ ), the Falkenberg phase (990 $970 \mathrm{Ma}$ ) and, finally, the Dalane phase (970 $900 \mathrm{Ma}$ ). Metamorphism in the orogen has a high pressure sig nature towards the east (Möller and Andersson, 2018; Möller et al., 2015; Söderlund et al., 2008), contrasting with a high tempera ture low pressure signature in the west (Blereau et al., 2017; Laurent et al., 2016). The orogeny ended with pulses of granite and anorthosite mangerite charnockite (AMC) plutonism around 930 Ma (Vander Auwera et al., 2011) and of pegmatite intrusion around $910 \mathrm{Ma}$ (Müller et al., 2017).

\subsection{Eastern Segment}

The Eastern Segment (Fig. 1) is bounded in the east by the Sveconorwegian Front and in the west by the "Mylonite Zone", a prominant top to the east mid crustal thrust (Andersson et al., 2002; Viola et al., 2011). The Eastern Segment is characterized by protoliths mainly formed between 1780 and 1660 Ma that are ascribable to the Trans candinavian Igneous Belt (TIB) and Svecokarelian foreland of the orogen (Fig. 2) (Appelquist et al., 2008; Högdahl et al., 2004; Möller et al., 2007; Petersson et al., 2015a; Söderlund et al., 1999). It was affected by an early orogenic event, known as Hallandian or Danopo lonian, between 1465 and 1370 Ma (Brander and Söderlund, 2009; Cecys and Benn, 2007; Ulmius et al., 2015). Sveconorwegian 


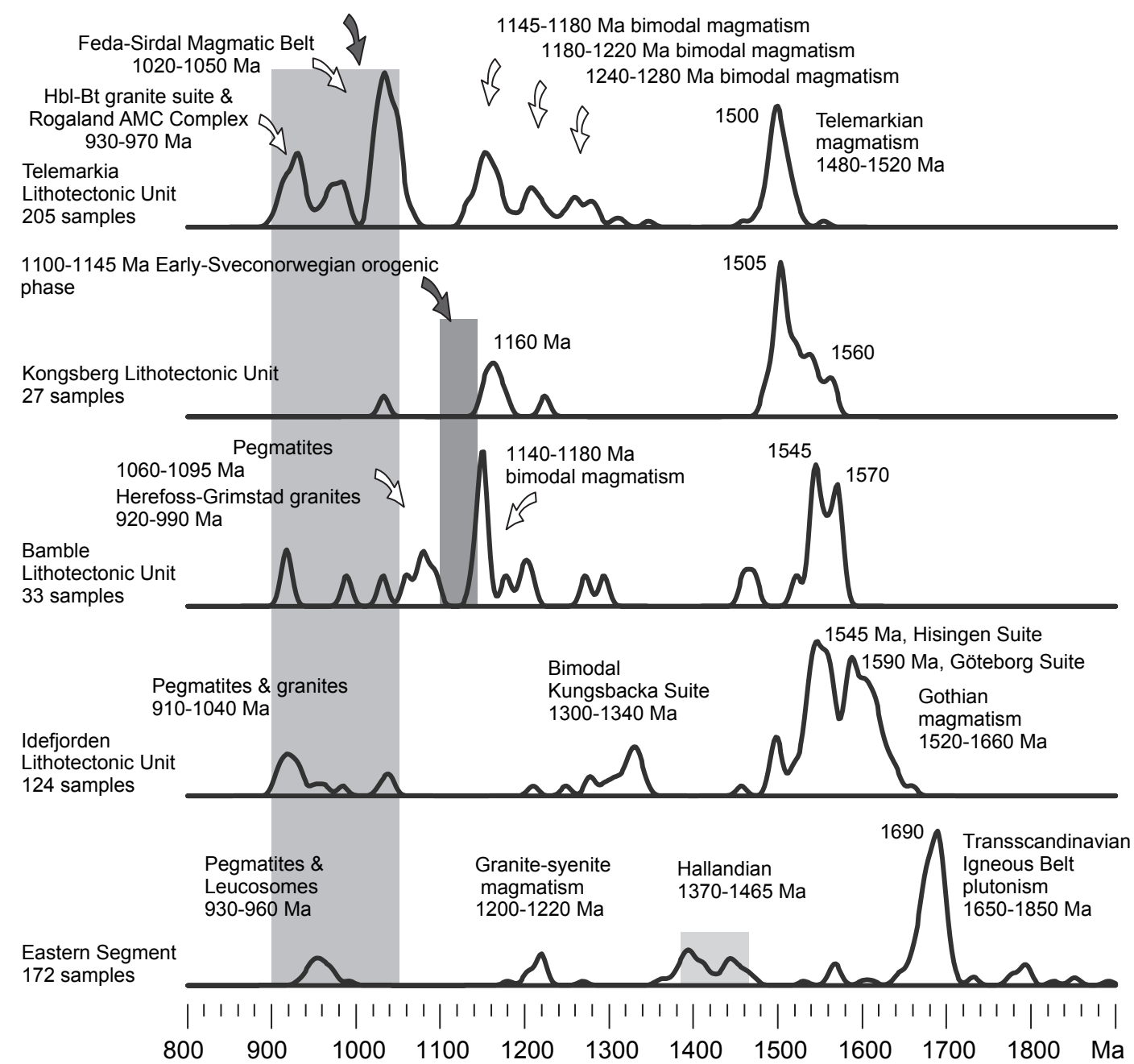

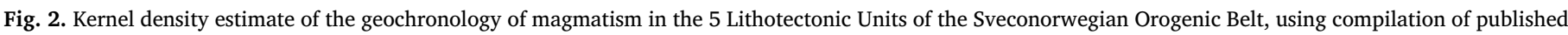

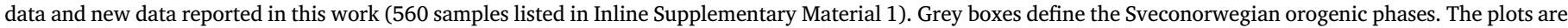

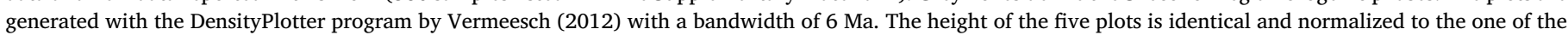
largest peak.

deformation and metamorphism increases westwards in the Eastern Segment (Möller and Andersson, 2018; Möller et al., 2015; Piñán Llamas et al., 2015). Metamorphism peaked in eclogite facies conditions at c. $990 \mathrm{Ma}$. Retro eclogite bodies are preserved in a recumbent fold, c. $70 \mathrm{~km}$ wide, in the footwall of the Mylonite Zone (Möller and Andersson, 2018; Möller et al., 2015).

\subsection{Idefjorden Lithotectonic Unit}

The Idefjorden Unit is c. $140 \mathrm{~km}$ wide and exposed on either side of the Permian Oslo Rift (Fig. 1) (Åhäll and Connelly, 2008; Åhäll and Gower, 1997; Bingen et al., 2001b; Viola et al., 2011). It is character ized by a N S to NW SE Sveconorwegian structural grain parallel to the Mylonite Zone, well visible on aeromagnetic maps. It is divided along its length by the Ørje Shear Zone in Norway and the Göta Älv Shear Zone in Sweden (Fig. 1) (Park et al., 1991; Viola et al., 2011; Wahlgren et al., 2015). East of the Oslo Rift, the gneissic foliation dips unimodally to the NE (Viola et al., 2011, their Fig. 2).

The Idefjorden Unit is made up of Gothian plutonic and volcanic rocks formed mainly between 1660 and $1520 \mathrm{Ma}$, associated with metasedimentary rocks (Fig. 2) (Åhäll and Connelly, 2008; Åhäll and Larson, 2000; Andersen et al., 2004a; Bingen et al., 2005; Brewer et al., 1998; Graversen and Pedersen, 1999). These rocks young towards the west. From east to west, three complexes (called formations or belts in the literature) are described (Åhäll and Connelly, 2008; Brewer et al., 1998): the 16601640 Ma metavolcanic Horred Complex, the 16301590 Ma metavolcanic and metasedimentary Åmål Complex as sociated with the Göteborg granite suite, and, west of the Göta Älv Shear Zone, the 15901520 Ma metasedimentary and metavolcanic Stora Le Marstrand Complex, associated with the 15801520 Ma plu tonic Hisingen Suite.

The Stora Le Marstrand Complex, exposed east of the Oslo Rift, correlates with the Veme Complex west of the Oslo Rift (Fig. 3) (Bingen et al., 2001b). The Stora Le Marstrand and Veme Complex comprise several metasedimentary successions, probably deposited in several basins ( $\AA$ häll and Connelly, 2008). They consist of thick packages of turbiditic psammite and greywacke metamorphosed under amphibo lite facies conditions (Bingen et al., 2001b). Sedimentation started be fore c. $1585 \mathrm{Ma}$ (folded metagreywacke xenoliths in a $1584 \pm 7$ Ma granite pluton) and continued after c. $1533 \pm 16$ Ma (detrital zircon geochronology in nine samples including four new samples in this study; Fig. 4) (Åhäll and Connelly, 2008; Åhäll et al., 1998; Bingen et al., 2001b).

The 16601520 Ma Gothian rocks are overlain by the undated Dal Group, a c. $2 \mathrm{~km}$ thick succession of clastic sediments and basalt (Brewer et al., 2002). The Gothian rocks are intruded by the 


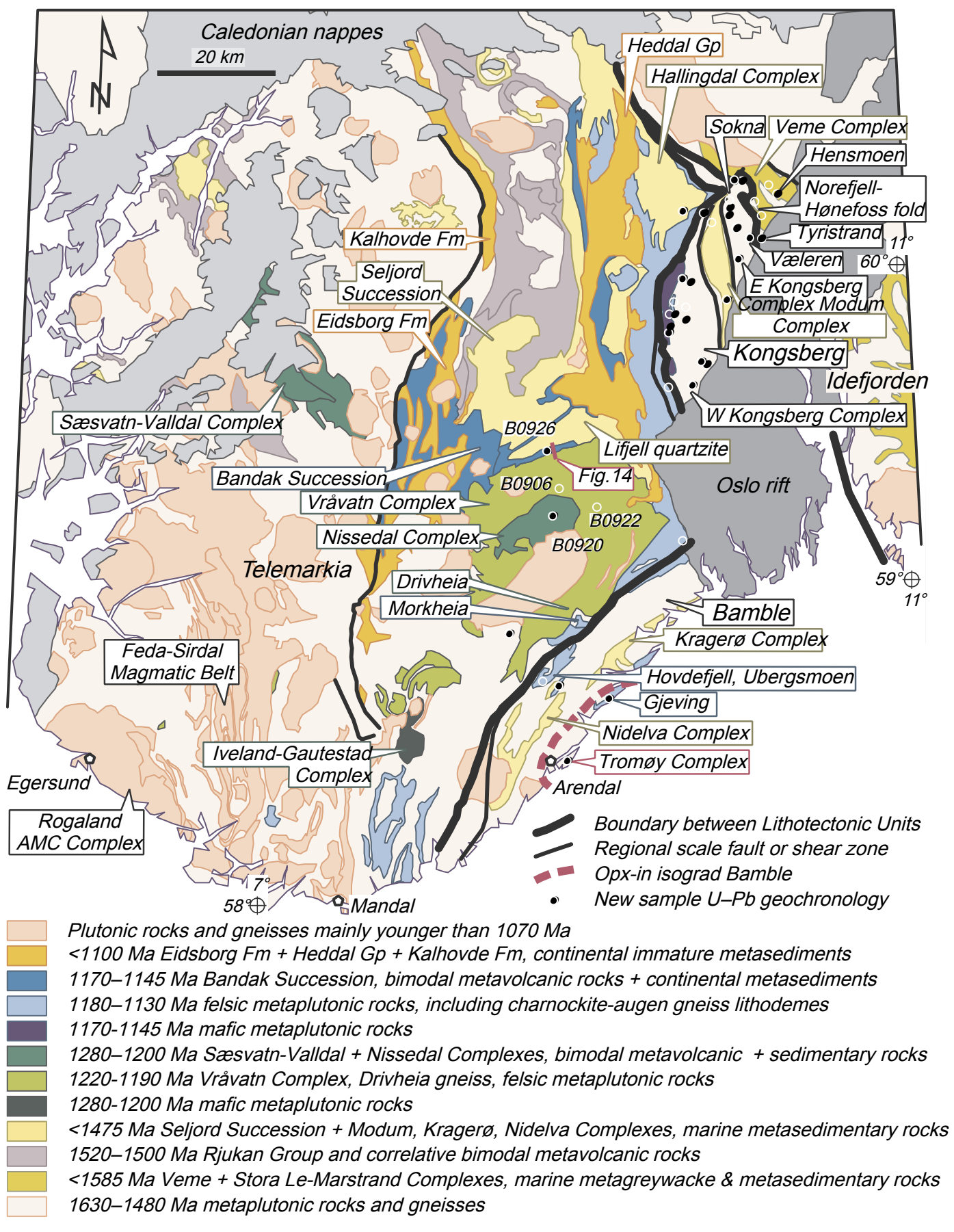

Fig. 3. Sketchmap of Southern Norway, highlighting Pre- to Early-Sveconorwegian magmatic suites and sampling of this study.

$1457 \pm 6$ Ma, N S trending Orust mafic dykes (Åhäll and Connelly, 1998), and the 13401305 Ma bimodal Kungsbacka Suite (Austin Hegardt et al., 2007).

In the Idefjorden Unit, Sveconorwegian metamorphism is of variable intensity and ranges from greenschist to granulite facies, resulting in a patchwork of low grade and high grade rocks. High pressure granulite facies assemblages are reported from metadolerite dykes hosted in amphibolites facies gneisses from several localities east of the Göta Älv Shear Zone (Fig. 1) (Söderlund et al., 2008). Zircon U Pb data bracket this metamorphism to between $1046 \pm 6$ and $1026 \pm 5$ Ma (Söderlund et al., 2008). West of the Göta Älv Shear Zone, amphibolite facies metamorphism is dated to between $1043 \pm 11 \mathrm{Ma}$ and c. $1023 \mathrm{Ma}$ (Åhäll et al., 1998; Austin Hegardt et al., 2007; Hansen et al., 1989). In the Veme Complex, high pressure granulite facies conditions are recorded in a kyanite garnet rutile paragneiss with a monazite age of $1052 \pm 4 \mathrm{Ma}$ (Bingen et al., 2008b).

The Idefjorden Unit contains a rich record of magmatism and ductile to brittle deformation, post dating the peak of metamorphism after 1050 Ma (Fig. 2) (Årebäck et al., 2008; Hellström et al., 2004; Lamminen et al., 2011; Müller et al., 2017; Wahlgren et al., 2015).

\subsection{Kongsberg Lithotectonic Unit}

The Kongsberg Unit (Figs. 1,3 and 5) is $25 \mathrm{~km}$ wide and $90 \mathrm{~km}$ long. It is characterized by a N S structural grain that reflects the tight jux taposition of $13 \mathrm{~km}$ thick elongate units of steeply dipping, isoclinally folded gneisses (Fig. 6) (Starmer, 1985; Viola et al., 2016). The Kongsberg Unit is bounded in the west by the Saggrenda Sokna Shear 


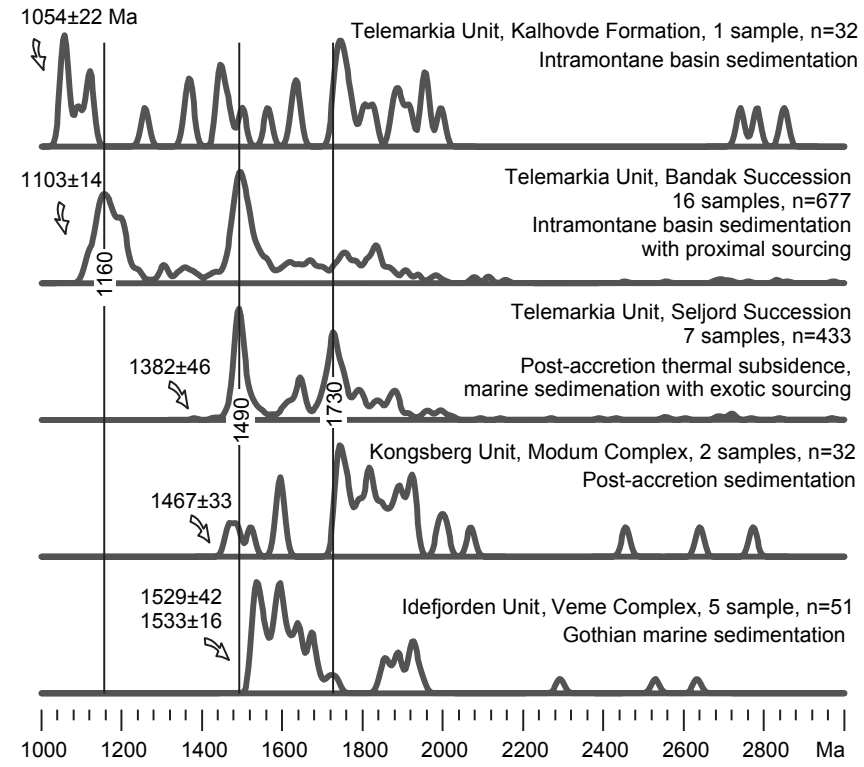

Fig. 4. Kernel density estimate of the age of detrital zircons in the main clastic sediment sequences of the Telemarkia and Kongsberg Units, from the literature and this work. The plots are generated with a bandwidth of $10 \mathrm{Ma}$, and show analyses with discordance $<5 \%$. For each curve the total number of samples and analyses (n) are specified. The age of the youngest analyzed clastic zircon is specified for each plot. Samples are listed in Inline Supplementary Material 2 from deHaas et al. (1999), Bingen et al. (2001b; 2002; 2003), Lamminen and Köykkä (2010), Lamminen(2011), Spencer et al. (2014).

Zone (Fig. 5) (Starmer, 1985), an east dipping multiphase shear zone (Scheiber et al., 2015). The youngest brittle reactivation thereof, traditionally referred to as the "Great Friction Breccia" ("store rivnings breksje" in Norwegian) (Starmer, 1985) is of probable Permian age (Larsen et al., 2008; Scheiber et al., 2015).

Two distinct lithological complexes are defined in the Kongsberg Unit (Viola et al., 2016): (i) The Kongsberg Complex consists of variably banded orthogneiss units of quartz dioritic, dioritic, granodioritic and granitic composition (Fig. 6). Orthogneisses range from fine to coarse grained and have both volcanic and plutonic protoliths. The Kongsberg Complex contains layers of sulfide rich schist, called "fahlband" in the regional literature, that host the historical silver mines around the city of Kongsberg (Gammon, 1966). (ii) The Modum Complex is a c. $9 \mathrm{~km}$ wide metasedimentary complex sandwiched in the middle of the Kongsberg Complex (Fig. 5) (Viola et al., 2016). The Modum Complex consists dominantly of coarse quartzite deposited after $1467 \pm 33$ Ma (youngest detected detrital zircon, Fig. 4), mica schist, sillimanite gneiss and locally sulfide rich fahlbands (Andersen and Grorud, 1998; Bingen et al., 2001b). It hosts minor volume of metasomatic lithologies such as orthoamphibole cordierite gneiss, talk schist, albitite and sca politite (Munz, 1990; Munz et al., 1994).

The Kongsberg Unit is characterized by early Sveconorwegian de formation and metamorphism. Metamorphism ranges from epidoteamphibolite facies to granulite facies. As documented in more detail below, the high grade metamorphism is dated between 1145 and $1130 \mathrm{Ma}$.

\subsection{Bamble Lithotectonic Unit}

The NE SW trending c. $25 \mathrm{~km}$ wide and $140 \mathrm{~km}$ long Bamble Unit (Figs. 3 and 7) shares many similarities with the Kongsberg Unit, such that these two units are generally correlated (Bugge, 1936; Starmer, 1985). The Bamble Unit is separated in the north from the Telemarkia Unit by the southeast dipping Kristiansand Porsgrunn Shear Zone (Figs. 1 and 7). Bamble consists of thin, c. 1 to $5 \mathrm{~km}$ thick, steeply dipping and tightly to isoclinally folded high grade gneiss units (Fig. 7)
(Henderson and Ihlen, 2004; Nijland et al., 2014; Padget and Brekke, 1996; Starmer, 1985). These comprise orthogneiss with an homo geneous gabbroic, granodioritic, tonalitic or granitic composition, but also compositionally more heterogeneous and commonly migmatitic gneisses. They can be fine grained, tightly layered or banded, and locally host sulfide bearing or graphite bearing schist and sandstone in tercalations (Broekmans et al., 1994; deHaas et al., 2002a). They can be interpreted as representing sequences of interlayered metavolcanic and metasedimentary rocks. Orthogneisses range in age from $1572 \pm 20$ to $1460 \pm 21 \mathrm{Ma}$ (Fig. 2) (Andersen et al., 2004a; deHaas et al., 2002a; Engvik et al., 2016; Kullerud and Machado, 1991). The Bamble Unit also includes two distinctive quartzite rich metasedimentary com plexes, the Nidelva and Kragerø Complexes. These are similar to the Modum Complex in Kongsberg, including the presence of metasomatic rocks (Engvik et al., 2014; Morton, 1971; Nijland et al., 2014; Nijland et al., 1993).

The gneiss complexes were intruded by felsic and mafic plutonic rocks between 1180 and $1140 \mathrm{Ma}$ (Fig. 2) (Andersen et al., 2004b; Engvik et al., 2016). The Bamble Unit is characterized by early Sveconorwegian high grade metamorphism, increasing southeastwards towards the islands of Tromøy and Hisøy from amphibolite to granulite facies conditions (Figs. 3 and 7) (Clough and Field, 1980; Nijland et al., 2014; Nijland and Maijer, 1993; Touret, 1971a). As discussed below, the timing of high grade metamorphism is constrained between 1145 and 1120 Ma (Bingen et al., 2008b; Cosca et al., 1998; Engvik et al., 2016; Knudsen et al., 1997). Two unfoliated late Sveconorwegian granite plutons crosscut the gneiss fabric (Fig. 7).

\subsection{Telemarkia Lithotectonic Unit}

The western part of the Sveconorwegian Orogenic Belt can be regarded as one single, $230 \mathrm{~km}$ wide and $300 \mathrm{~km}$ long, lithotectonic unit, named Telemarkia by Bingen et al. (2005). The hallmark of the Telemarkia Unit is a voluminous and short lived magmatic event between 1520 and $1480 \mathrm{Ma}$ (Fig. 2), referred to as Telemarkian (Bingen et al., 2008a; Bingen et al., 2005; Laajoki and Corfu, 2007; Pedersen et al., 2009; Roberts et al., 2013).

The central and northern part of the Telemarkia Unit exposes stratiform volcanic and sedimentary rocks affected by low grade metamorphism (Dons, 1960a; Dons, 1960b; Sigmond, 1978). The classic Telemark supracrustal rocks are exposed in a $60 \mathrm{~km}$ wide area (Fig. 3). They contain well preserved syn sedimentary or syn volcanic structures and stratigraphic relationships and are folded by map scale open to close folds. Early mapping divided the Telemark supracrustal rocks into three successions, separated by unconformities (Dons, 1960a; Dons and Jorde, 1978; Sigmond, 1978). These are, from bottom to top, the Rjukan, Seljord and Bandak Successions, then called groups. Later characterization work has led to a proliferation of group names inside the Seljord and Bandak Successions (Laajoki et al., 2002). For simplicity we prefer to maintain inhere the fundamental threefold division (Fig. 3), as summarized in Spencer et al. (2014).

The Rjukan Group/Succession is made of bimodal volcanic rocks dated between $1512 \pm 10$ and $1495 \pm 2$ Ma (Bingen et al., 2005; Laajoki and Corfu, 2007), thus belonging to the Telemarkian magma tism. It is not known to overly any older basement. The Seljord Succession is a c. $8 \mathrm{~km}$ thick, shallow marine, exclusively sedimentary succession, dominated by tidally influenced quartzite (Köykkä and Lamminen, 2011). It was deposited during a transgressive cycle, between $1382 \pm 46$ Ma (youngest detected detrital zircon, Fig. 4) and $1347 \pm 4 \mathrm{Ma}$ (intrusive diabase dyke; Corfu and Laajoki, 2008; Lamminen and Köykkä, 2010).

The Bandak Succession is c. $3.5 \mathrm{~km}$ thick and covers both the Rjukan and Seljord Successions (Köykkä, 2011; Laajoki et al., 2002), above a first order unconformity (sub Svinsaga unconformity; Köykkä and Laajoki, 2009). The lower part of the Bandak Succession consists of bimodal volcanic rocks interlayered with coarse grained clastic 


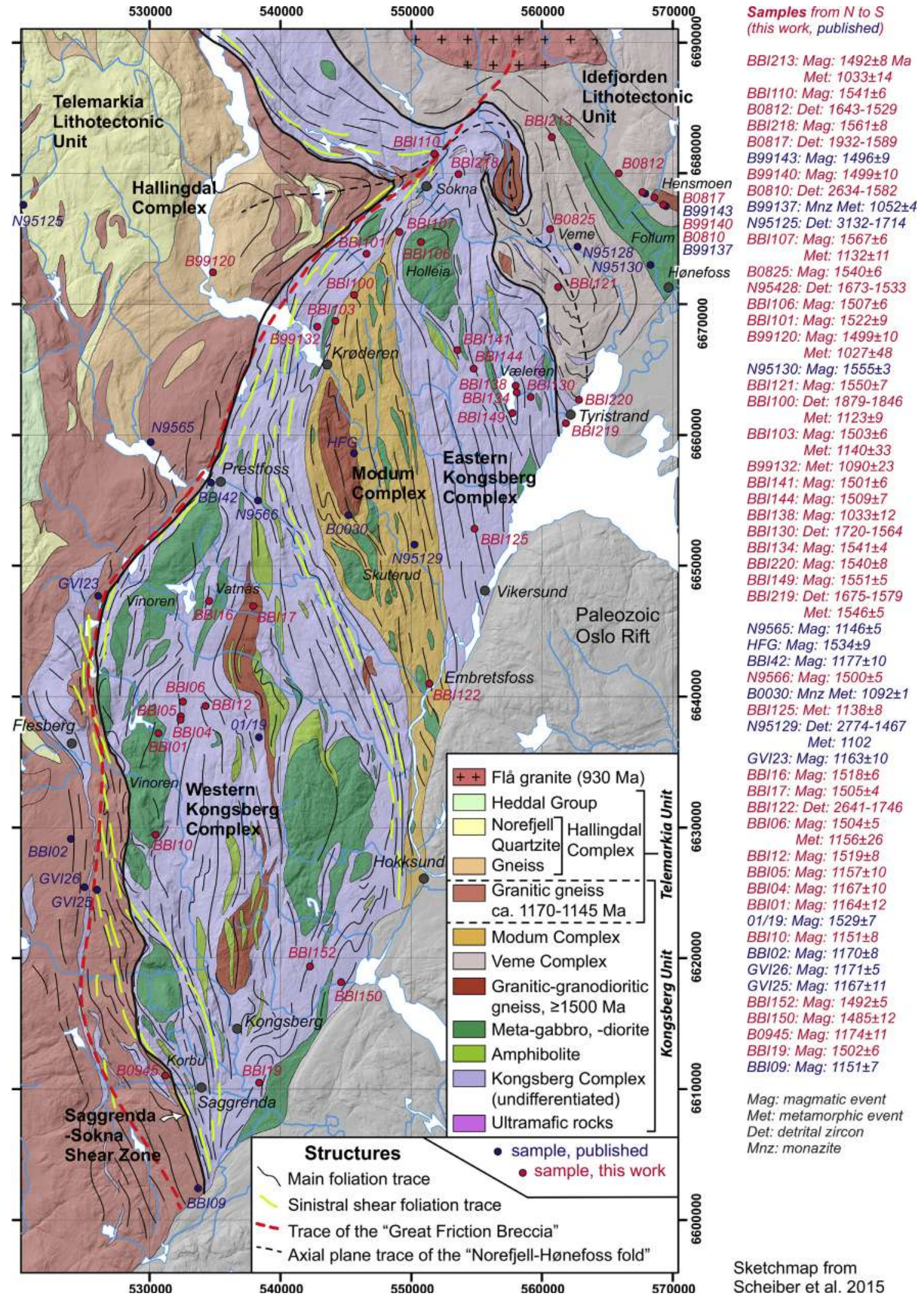

Fig. 5. Sketchmap of the Kongsberg Lithotectonic Unit following Scheiber et al. (2015), with sampling of this study.

sediments (Svinsaga and Røynstaul formations; Köykkä, 2011). The felsic volcanic rocks range in age from $1169 \pm 9$ to $1145 \pm 4 \mathrm{Ma}$ (Bingen et al., 2003; Laajoki et al., 2002). The upper part of the Bandak Succession consists of exclusively clastic sedimentary rocks, known as the Eidsborg Formation, Heddal Group and Kalhovde Formation
(Fig. 3). Detrital zircon data provide a maximum sedimentation age of $1116 \pm 24$ Ma for the Heddal Group, $1103 \pm 14$ Ma for the Eidsborg Formation, and $1054 \pm 22 \mathrm{Ma}$ for the Kalhovde Formation (Fig. 4) (Bingen et al., 2003; deHaas et al., 1999; Lamminen, 2011; Spencer et al., 2014). 


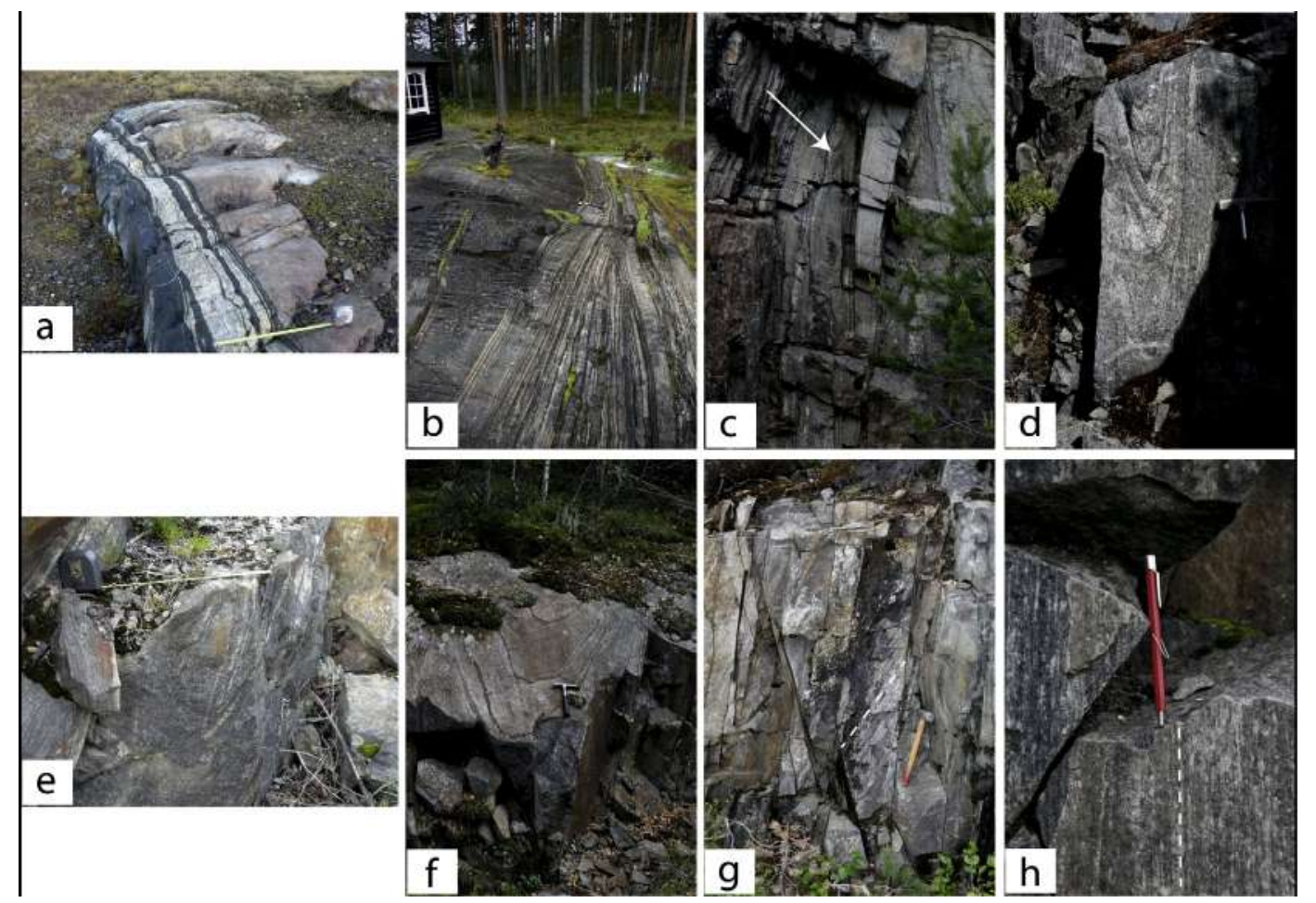

Fig. 6. Field examples of amphibolite-facies layered gneisses with steep foliation, isoclinal folds (c, $d, e, f$, white arrow), and steep lineation (g, h).

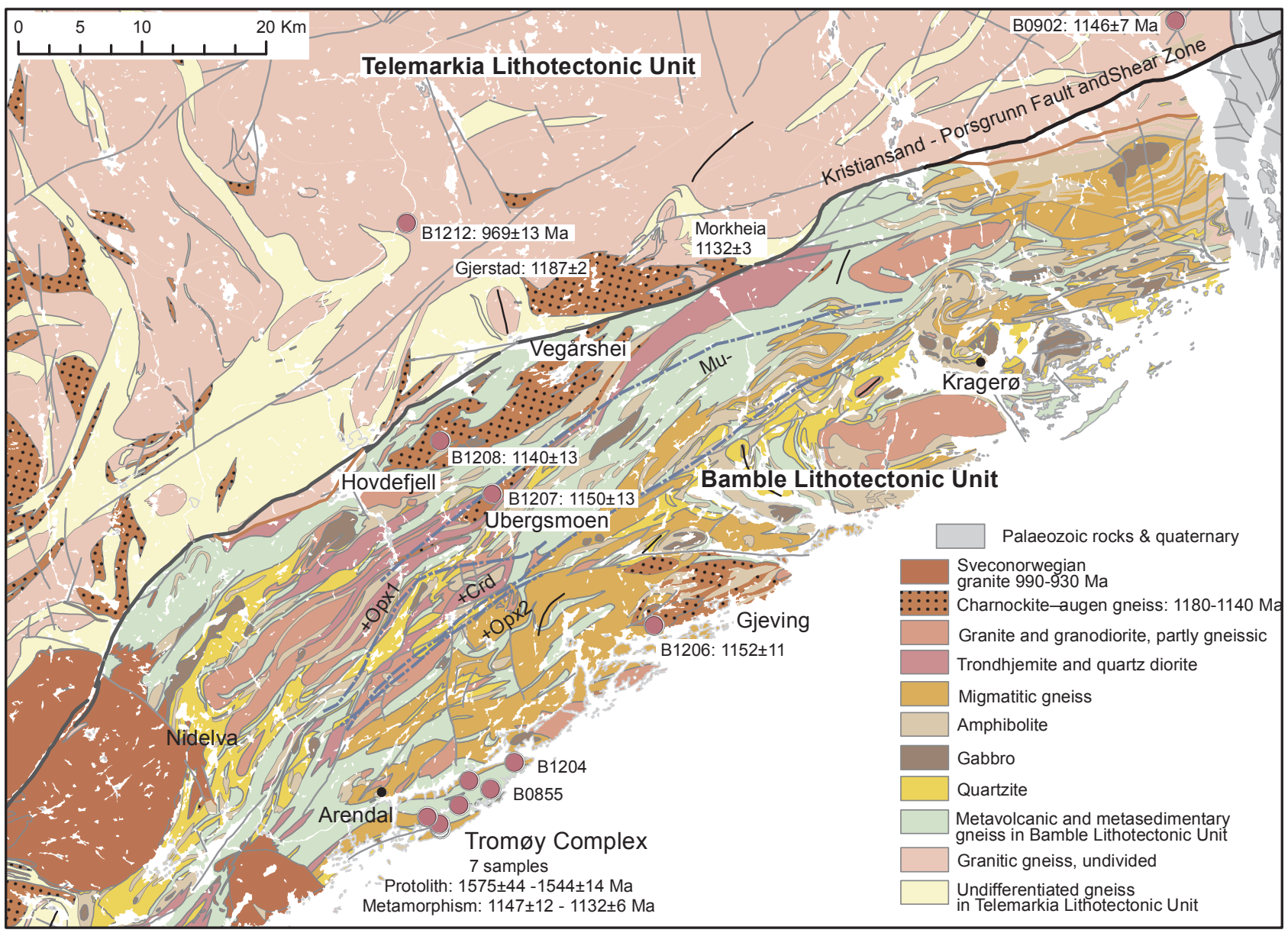

Fig. 7. Sketchmap of the Bamble Lithotectonic Unit following Padget and Brekke (1996), with sampling of this study. 
The Nissedal and the Sæsvatn Valldal Complexes (Fig. 3) represent two more low grade stratiform successions (Sigmond, 1975). In the Sæsvatn Valldal Complex, rhyolite and subvolcanic porphyries dated between $1275 \pm 8$ and $1259 \pm 2 \mathrm{Ma}$ (Bingen et al., 2002; Brewer et al., 2004) unconformably overly a 15201480 Ma gneissic basement, and are in turn overlain by basalt and minor sedimentary rocks. The Nissedal Complex is dominated by basalt.

High grade gneisses in the Telemarkia Unit host multiple intrusions of bimodal (within plate) plutonic rocks in the 12801240,12301200 and $11801140 \mathrm{Ma}$ time intervals, with frequency maxima at c. 1280, 1260, 1210, 1170 and 1150 Ma (Fig. 2) (Andersen et al., 2007; Bingen et al., 2003; Corfu and Laajoki, 2008; Heaman and Smalley, 1994; Pedersen et al., 2009; Scheiber et al., 2015). These maxima match the age of volcanism in the low grade stratiform successions. Intrusion of the alkaline and ferroan Morkheia monzonite suite at $11341130 \mathrm{Ma}$, just north of the Bamble Telemark boundary zone (Heaman and Smalley, 1994), was followed by almost total magmatic quiescence between 1130 and $1060 \mathrm{Ma}$. Magmatism resumed in the western part of the Telemarkia Unit with the emplacement of the c. $50 \mathrm{~km}$ wide, NNW SSE trending Feda Sirdal Magmatic Belt between 1050 and 1020 Ma (Fig. 3) (Bingen et al., 2015; Coint et al., 2015; Slagstad et al., 2013).

In the Telemarkia Unit, Sveconorwegian metamorphism ranges from greenschist to granulite facies conditions. The stratiform rocks were affected by low grade metamorphism and open folding after de position of the youngest sedimentary formation, i.e. after the Kalhovde Formation deposited after $1054 \pm 22$ Ma (Bingen et al., 2003). In the Sæsvatn Valldal Complex, metamorphism and deformation of the basalts were dated to $1032 \pm 2$ Ma by molybdenite Re Os geochronology (Stein and Bingen, 2002). In the gneiss complexes, the metamorphic grade reached amphibolite facies conditions between c. 1025 and 1005 Ma (Bingen et al., 2008b; Coint et al., 2015). Southwestward, the metamorphic grade increases to reach granulite facies in the vicinity of the c. 930 Ma Rogaland AMC Complex (Fig. 3) (Blereau et al., 2017; Tobi et al., 1985). Metamorphic zircon and monazite from a variety of samples from this metamorphic gradient range from c. 1040 to $900 \mathrm{Ma}$, with two frequency maxima, one between 1030 and $970 \mathrm{Ma}$ and the other around $930 \mathrm{Ma}$ (Bingen et al., 2008b; Bingen and van Breemen, 1998; Drüppel et al., 2013; Laurent et al., 2018; Laurent et al., 2016; Möller et al., 2002; Möller et al., 2003; Slagstad et al., 2018). Both maxima record ultra high temperature low pressure metamorphic conditions, implying extreme heat flow in the crust at the southwestern end of the orogen, associated with magmatic activity (Laurent et al., 2018; Slagstad et al., 2018). Late Sveconorwegian plutonism includes a suite of hornblende biotite granitoids intruded between 980 and $930 \mathrm{Ma}$ and the Rogaland AMC Complex at 930 Ma (Bolle et al., 2018; Slagstad et al., 2018; Vander Auwera et al., 2011).

\section{Methods and results: U Pb geochronology}

New geological mapping of the entire Kongsberg Unit and its bounding shear zones was recently completed together with more focussed mapping of one transect across the Bamble Unit. This work has resulted in a large field database and the compilation of a 1:100.000 geological map of the Kongsberg Unit (Viola et al., 2016), from which this study has taken inspiration.

Zircon $\mathrm{U} \mathrm{Pb}$ geochronological data were collected by Secondary Ion Mass Spectrometry (SIMS) (Jeon and Whitehouse, 2015; Whitehouse and Kamber, 2005) in 48 samples and by Laser Ablation Inductively Coupled Plasma Mass Spectrometry (LA ICP MS) in 6 samples. Analy tical protocols, sample properties, results and data are summarized in Table 1 and Inline Supplementary Materials 36 .

The age of the magmatic protolith of 27 orthogneiss samples in the Idefjorden, Kongsberg, Bamble and Telemarkia Units improve considerably the documentation of the Gothian to Telemarkian magmatism. Detrital zircon cores were analyzed in seven paragneiss samples. Only a few cores were analysed in each of them, enough, though, to demonstrate the clastic nature of the protolith. Magmatic zircon was analyzed in 13 samples of deformed pre to early Sveconorwegian or thogneiss, in order to define the timing of magmatism preempting the orogeny and to bracket metamorphism. Metamorphic zircon crystals or zircon rims were successfully analyzed in 16 of the samples. For 10 of them, zircon provides robust age constraints to amphibolite and granulite facies metamorphic events.

\subsection{Kongsberg Unit, Gothian Telemarkian orthogneisses, 15671485 Ma}

In the following text, the Kongsberg Complex is divided into two sub complexes, situated to the east and to the west of the metasedimentary Modum Complex, respectively (Figs. 3 and 5) (Viola et al., 2016).

\subsubsection{BBI107, quartz dioritic layer in banded gneiss, eastern Kongsberg Complex}

The oldest dated orthogneiss was collected near the town of Sokna (Fig. 5), from a thin package of tightly banded orthogneiss of the Kongsberg Complex, between the Modum Complex in the west and the Holleia metagabbro in the east. The locality exhibits banded gneiss with 2 to $20 \mathrm{~cm}$ thick layers of tonalitic to quartz dioritic composition and some pegmatite layers. Felsic layers may represent deformed leucosome. The sample is from a garnet bearing quartz dioritic layer. Zircon shows a core rim structure, with a generally oscillatory zoned core surrounded by a CL dark rim generally thin and locally replacing the core. The core commonly contains inclusions and fractures filled by very luminescent zircon. Analyses of the core yield an age of $1567 \pm 6 \mathrm{Ma}$ (Fig. 8a, SIMS data, ${ }^{207} \mathrm{~Pb} /{ }^{206} \mathrm{~Pb}$ age, $\mathrm{n}=8$, MSWD $=0.60$; $\mathrm{Th} / \mathrm{U}=$ 0.47 ) recording crystallization of the protolith of the gneiss. Only a few analyses could be safely placed in the rim. Four of those define a good concordant cluster with an age of $1132 \pm 11$ Ma (Fig. 8b, MSWD $=2.3$ ) and three additional ones yield a younger age of $1095 \pm 9 \mathrm{Ma}$ (Fig. 8b, MSWD $=2.3$ ). A few analyses scatter below $1567 \mathrm{Ma}$ or above $1132 \mathrm{Ma}$, probably reflecting partial Sveconorwegian resetting or mixture of core and rim material. The age of $1132 \pm 11$ Ma records crystallization of the $\mathrm{U}$ rich $(380<\mathrm{U}<880 \mathrm{ppm})$, Th poor $(\mathrm{Th} / \mathrm{U}<0.07)$ rim and by inference the amphibolite facies metamorphism observed in the outcrop.

\subsubsection{BBI218, quartz dioritic gneiss, eastern Kongsberg Complex}

Sample BBI218 was collected in the northern part of the eastern Kongsberg Complex, in the little Tuftinåsen quarry near Sokna (Fig. 5). At this locality, Scheiber et al. (2015) document a metre scale reverse shear zone with $\mathrm{E}$ plunging lineation and top to the west transport direction (their Fig. 8a). The sample is a sheared quartzdioritic gneiss from the center of the shear zone, recording amphibolite facies de formation. Widespread alteration of plagioclase and biotite attests to a low grade, post peak, fluid present alteration event in the sample. The sample was originally collected to test for the presence of zircon related to shearing. However, the thin luminescent rim observed around most zircon crystals, and possibly related to this event, is too thin to be analyzed. Zircon is generally rounded to prismatic and characterized by an oscillatory zoning. A cluster of 11 analyses is recording the intrusion of the magmatic protolith of the gneiss at $1561 \pm 8 \mathrm{Ma}$ (Fig. 8c, SIMS data, ${ }^{207} \mathrm{~Pb} /{ }^{206} \mathrm{~Pb}$ age, $\mathrm{n}=11$, MSWD $=1.18, \mathrm{Th} / \mathrm{U}=0.36$ ).

\subsubsection{BBI149, feldspar porphyry gneiss, eastern Kongsberg Complex}

Sample BBI149 was collected from a c. $50 \mathrm{~m}$ thick package of grey gneissic feldspar porphyry along the western shore of lake Væleren. The outcrop exposes also a c. $20 \mathrm{~m}$ thick mafic ultramafic hornblende rich metagabbro body. The porphyry shows variably granulated plagioclase megacrysts in a fine grained amphibole biotite bearing granodioritic matrix. This rock is intensely foliated and isoclinaly folded along steep fold axes (Fig. 6a). It contains thin bands with both mafic and felsic layers, possibly representing leucosome. Zircon crystals are stubby, 


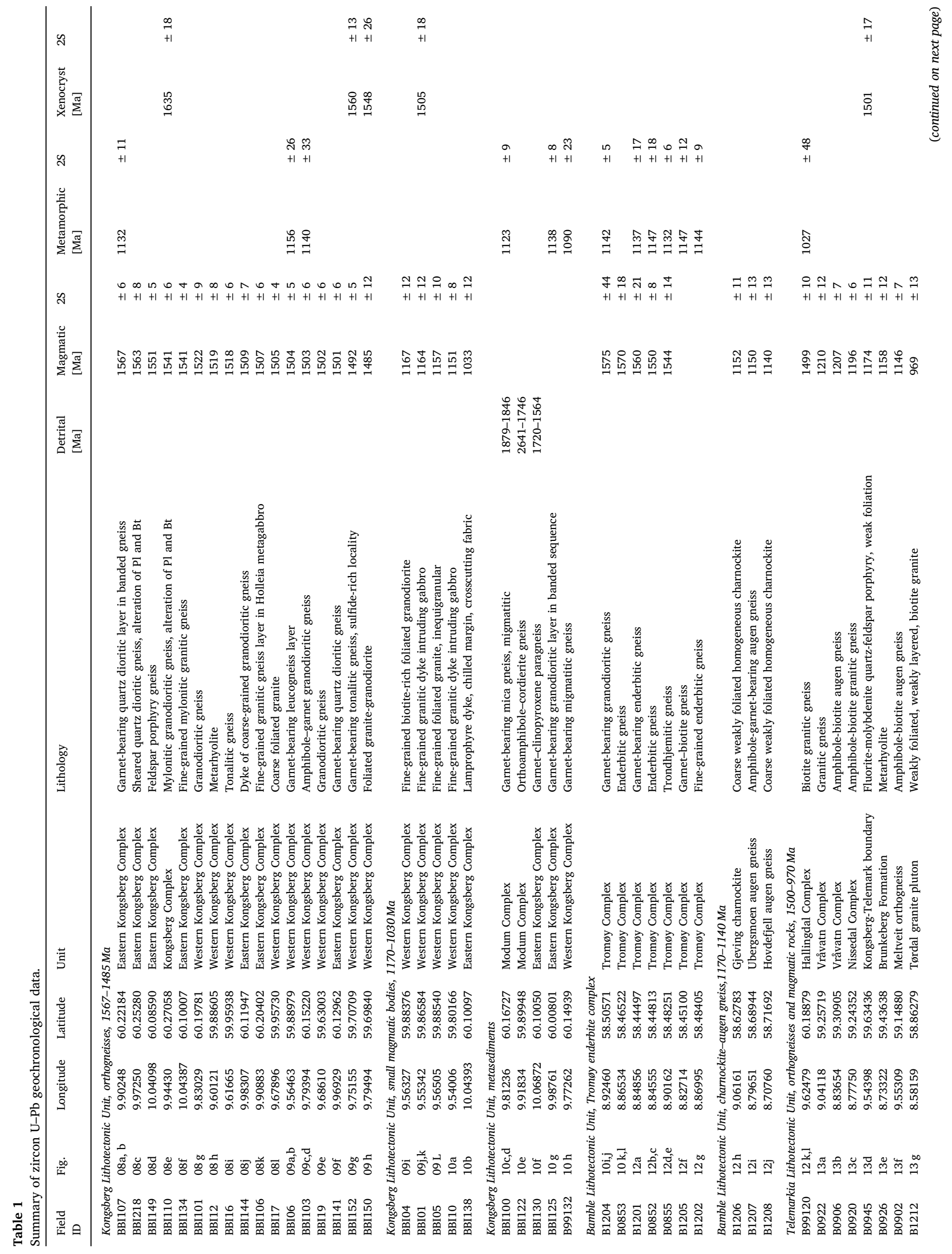




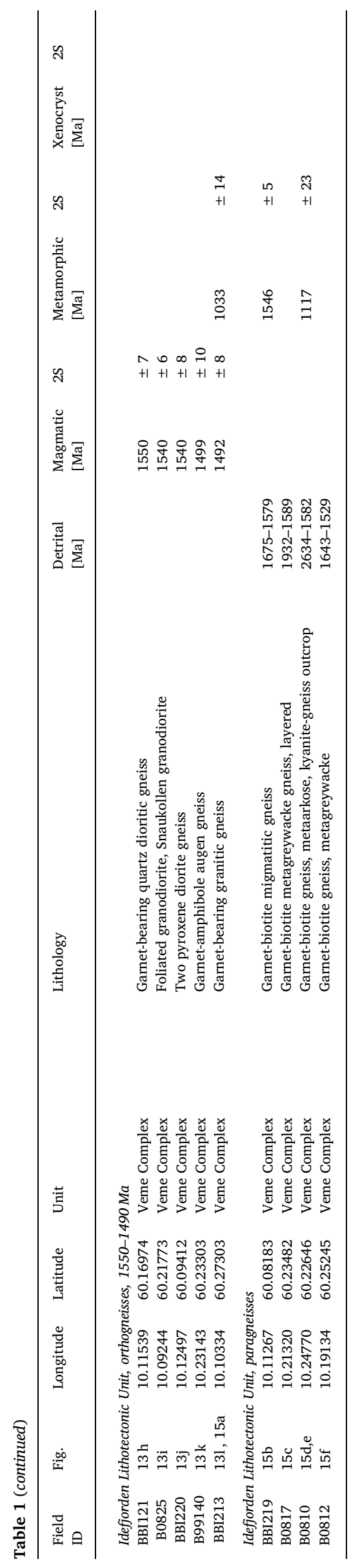

fractured, CL dark, $\mathrm{U}$ rich $(320<\mathrm{U}<1040 \mathrm{ppm})$ and characterized by convolute zoning. Analyses define a short discordia line with an upper intercept age of $1551 \pm 5 \mathrm{Ma}$ (Fig. 8d, SIMS data, $\mathrm{n}=12$, MSWD $=$ $1.17, \mathrm{Th} / \mathrm{U}=0.46$ ), interpreted as the intrusion or extrusion age of the feldspar porphyry.

\subsubsection{BBI110, mylonitic granodioritic gneiss, Kongsberg Complex}

Sample BBI110 was collected in the northern part of the Kongsberg Unit (Fig. 5), where brittle to ductile structures of the Great Friction Breccia intersect the axial surface of the geometrically complex Norefjell Hønefoss fold described by Scheiber et al. (2015) (their Fig. 9). The walls of a large gravel quarry expose a N S trending, east dipping, mylonitic granodioritic gneiss, with a SE plunging lineation. The gneiss is layered and variably sheared, with metric layers of augen gneiss, containing augens of feldspar up to $1 \mathrm{~cm}$ in size, and texturally more homogeneous layers. The sample was collected from a layer with $\mathrm{K}$ feldspar and plagioclase augens in a matrix with quartz ribbons, dy namically recrystallized quartz and chlorite decorated shear bands. The matrix also displays partly granulated garnet phenoblasts. The assemblages imply amphibolite facies metamorphism followed by greens chist facies retrogressive mylonitic deformation. Zircon crystals are rounded to prismatic, and oscillatory zoned. No evidence for zircon neoformation is observed, that could be attributed to the metamorphism and/or intense deformation observed in the sample, except for a few fractures sealed by dark CL contrast zircon. Oscillatory zoned zircon yields an age of $1541 \pm 6 \mathrm{Ma}$ (Fig. 8e, SIMS data; ${ }^{207} \mathrm{~Pb} /{ }^{206} \mathrm{~Pb}$ age, $\mathrm{n}=10, \mathrm{MSWD}=1.4, \mathrm{Th} / \mathrm{U}=0.38$ ) recording magmatic intrusion of the protolith of this orthogneiss. The dataset contains an inherited zircon core with an age of $1635 \pm 18 \mathrm{Ma}$.

\subsubsection{BBI134, mylonitic granitic gneiss, eastern Kongsberg Complex}

Sample BBI134 is a fine grained $(<100 \mu \mathrm{m})$ biotite amphibole felsic gneiss, previously mapped as leptite, and reinterpreted as a my lonitic granitic gneiss as part of a shear zone exposed along the eastern shore of lake Væleren (Fig. 5; opposite side of the lake relative to sample BBI149). The outcrop contains a pronounced N S trending, near vertical, planar fabric, isoclinally folded along steep fold axes. A steep stretching lineation is visible. The felsic gneiss is interlayered with layers of dioritic gneiss and contains boudins of amphibolite. In the boudins, patches rich in garnet and clinopyroxene replace the amphi bole rich assemblage, and attest to incipient granulite facies meta morphism at the locality. Sample BBI134 contains rounded to prismatic oscillatory zoned zircon, $100150 \mu \mathrm{m}$ in size, with rounded tips. Eight concordant analyses of rather high U zircon (200 $500 \mathrm{ppm} \mathrm{U}$ ) define a well clustered age of $1541 \pm 4$ Ma (Fig. 8f, SIMS data, ${ }^{207} \mathrm{~Pb} /{ }^{206} \mathrm{~Pb}$ age, $\mathrm{n}=8$, MSWD $=$ $0.85, \mathrm{Th} / \mathrm{U}=0.46$ ) recording magmatic intrusion of the protolith of the gneiss. The prominant shearing event observed in the outcrop is not recorded in the zircon population.

\subsubsection{BBI101, granodioritic gneiss, western Kongsberg Complex}

The sampling locality is close to the western boundary of the Kongsberg Unit (Fig. 5) and it is characterized by a gently SE dipping foliation and a well defined E plunging lineation. The locality contains thin layers of quartzo feldspathic or amphibolite gneiss. Sample BBI101 is a strongly sheared granodioritic gneiss with millimetre thick bands rich in biotite and amphibole. The sample contains up to $300 \mu \mathrm{m}$ prismatic oscillatory zoned zircon crystals, defining an intrusion age of 1522 $\pm 9 \mathrm{Ma}$ (Fig. 8g, SIMS data, ${ }^{207} \mathrm{~Pb} /{ }^{206} \mathrm{~Pb}$ age, $\mathrm{n}=8$, MSWD $=0.95$, Th/ $\mathrm{U}=0.34)$.

\subsubsection{BBI12, metarhyolite, western Kongsberg Complex}

Sample BBI12 (Fig. 5) was collected from an heterogeneous package of steeply dipping N S trending fine grained gneisses, showing epidote amphibolite facies metamorphism. The sequence is best interpreted as metavolcanic and the sample, which contains muscovite and sulfide, as a c. $100 \mathrm{~m}$ thick metarhyolite. Oscillatory zoned zircon yields a 

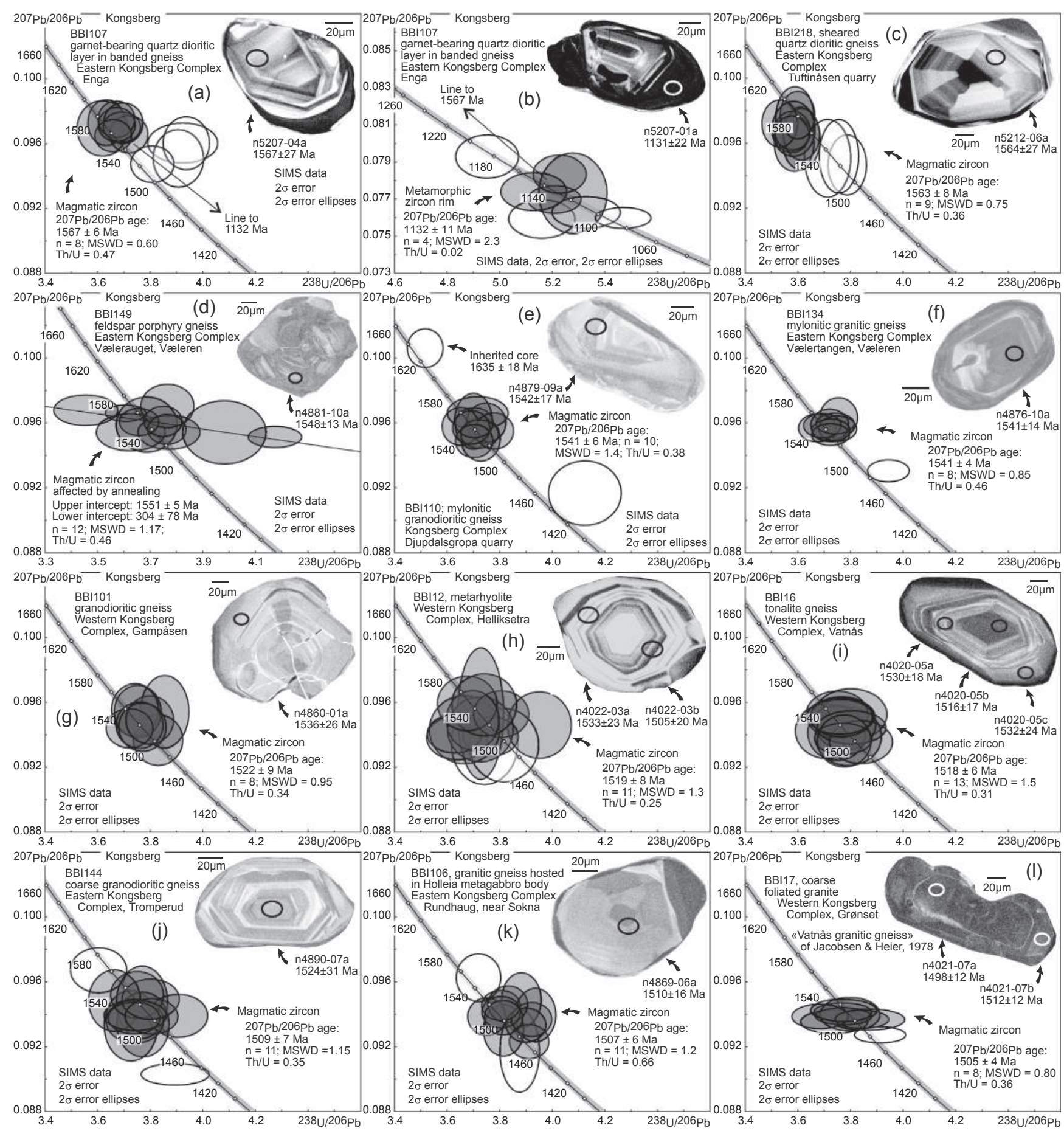

Fig. 8. Tera-Wasserburg concordia diagram with zircon U-Pb analyses and a selected CL image of zircon with position of analyses. Grey filled ellipses correspond to the analyses selected for age calculation, white ellipse are not selected. The samples are arranged in the order of presentation in Table 1, i.e. decreasing age for each catergory.

clustered age of $1519 \pm 8 \mathrm{Ma}$ (Fig. 8h, SIMS data, ${ }^{207} \mathrm{~Pb} /{ }^{206} \mathrm{~Pb}$ age, $\mathrm{n}=11, \mathrm{MSWD}=1.3, \mathrm{Th} / \mathrm{U}=0.25$ ), for the rhyolite deposition or in trusion of a subvolcanic granite.

\subsubsection{BBI16, tonalitic gneiss, western Kongsberg Complex}

Sample BBI16 represents a c. $1 \mathrm{~km}$ thick tonalitic gneiss in the western part of the Kongsberg Complex (Fig. 5). The foliation dips steeply, trends N S and records epidote amphibolite facies metamorphism. Oscillatory zoned zircon gives an age of $1518 \pm 6 \mathrm{Ma}$ (Fig. 8i, SIMS data, ${ }^{207} \mathrm{~Pb} /{ }^{206} \mathrm{~Pb}$ age, $\mathrm{n}=13, \mathrm{MSWD}=1.5$, Th/
$\mathrm{U}=0.31$ ), recording intrusion of the protolith of this gneiss.

3.1.9. BBI144, granodiorite, BBI141, quartz dioritic gneiss, eastern Kongsberg Complex

These samples are part of a c. $4 \mathrm{~km}$ thick NNW trending, steeply dipping, heterogeneous gneissic belt of mainly mafic composition (Fig. 5). This gneissic unit includes fine grained mafic rock, presumably metabasalt, dioritic to quartz dioritic gneiss and metagabbro. It is commonly garnet bearing, veined and migmatitic.

Sample BBI141 is from a veined, garnet bearing quartz dioritic 

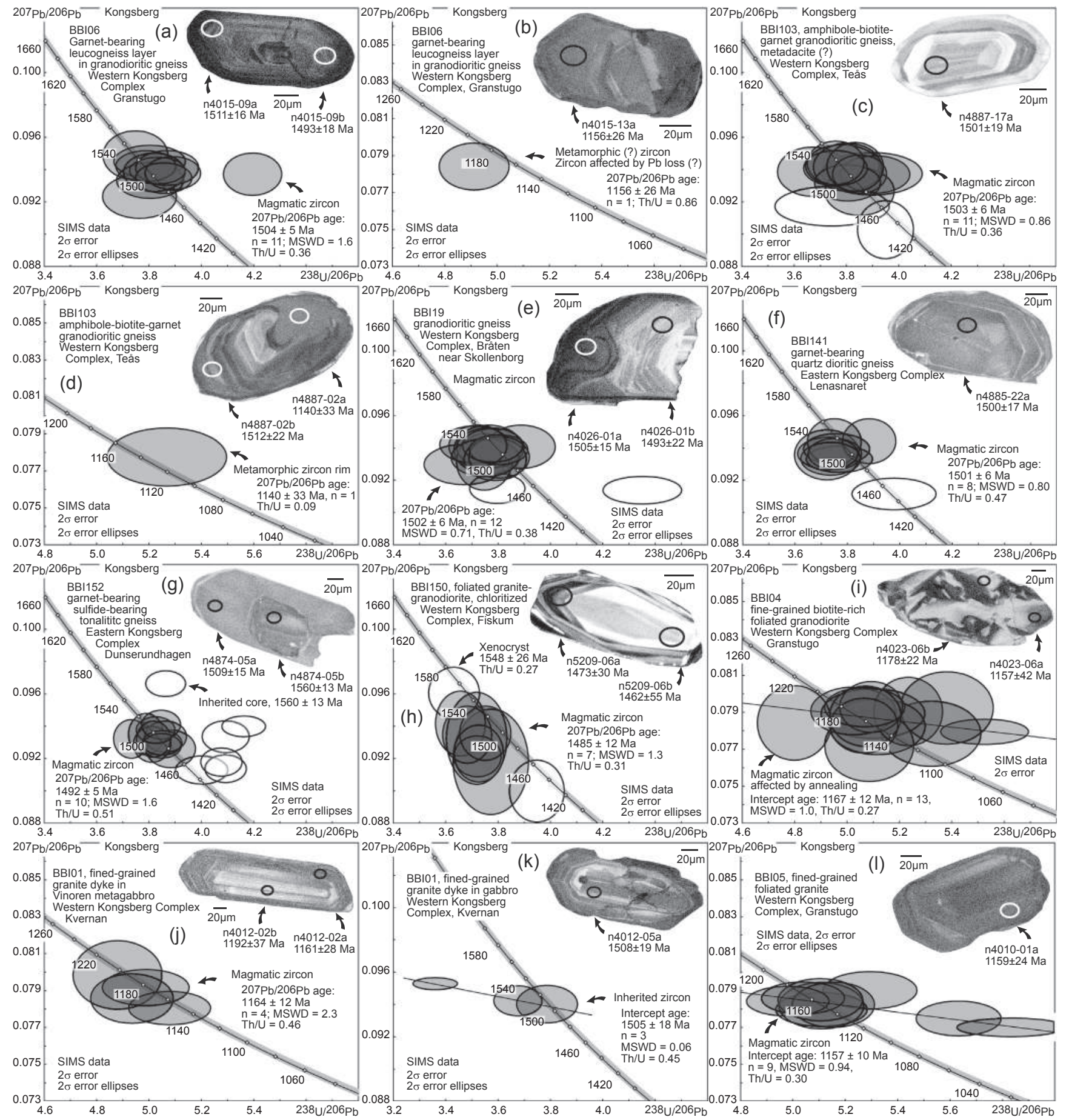

Fig. 9. Zircon $\mathrm{U}-\mathrm{Pb}$ data and selected $\mathrm{CL}$ images.

gneiss layer. Zircon crystals are prismatic, stubby and rounded. They exhibit a thin metamorphic rim, surrounding a commonly fractured oscillatory to sector zoned core. Eigth SIMS analyses of the core yield a ${ }^{207} \mathrm{~Pb} /{ }^{206} \mathrm{~Pb}$ age of $1501 \pm 6 \mathrm{Ma}$ (Fig. 9f, $\mathrm{n}=8, \mathrm{MSWD}=0.80$, Th/ $\mathrm{U}=0.47$ ), recording magmatic crystallization of the protolith of this gneiss. The rim could not be reliably analyzed.

Sample BBI144 was sampled from a weakly foliated, $3 \mathrm{~m}$ thick, granodioritic boudin, hosted in a sequence of well foliated, metabasalt and dioritic gneiss. The granodiorite contains amphibole and garnet up to $1 \mathrm{~cm}$ in diametre. The coarse grained character of the granodiorite boudin contrasts with the fined grained character of the host sequence. The boudin likely represents a stretched dyke in the metavolcanic sequence, deformed together with its host. Oscillatory zoned zircon yield an age of $1509 \pm 7 \mathrm{Ma}$ (Fig. 8j, SIMS data, ${ }^{207} \mathrm{~Pb} /{ }^{206} \mathrm{~Pb}$ age, $\mathrm{n}=11, \mathrm{MSWD}=1.15, \mathrm{Th} / \mathrm{U}=0.35$ ), for intrusion of the granodioritic rock.

3.1.10. BBI106, granitic gneiss in Holleia metagabbro, eastern Kongsberg Complex

The c. $4 \mathrm{~km}$ wide Holleia metagabbro body, near Sokna (Fig. 5), contains internal layering trending ENE WSW, visible on the aero magnetic map. This layering is clearly oblique and predates the tight NNW SSE trending gneissic fabric in the surrounding orthogneiss complex. Sample BBI106 represents a fine grained granitic gneiss layer 
of unspecified thickness in this metagabbro, with a foliation trending ENE WSW parallel to the internal layering of the metagabbro body. Oscillatory zoned zircon yields a magmatic crystallization of $1507 \pm 6$ Ma (Fig. 8k, SIMS data, ${ }^{207} \mathrm{~Pb} /{ }^{206} \mathrm{~Pb}$ age, $\mathrm{n}=11$, MSWD $=1.2$, Th/U $=0.66$ ) for the granite protolith of this layer. Contact relations are not exposed, and therefore, there is no unique way of interpreting relative chronology between the protoliths of the granite and host gabbro. The simplest interpretation is that the granite re presents a deformed aplite dyke or sill, therefore providing a minimum age of $1507 \pm 6$ Ma for intrusion of the gabbro pluton.

The NNW SSE trending orthogneiss units hosting the Holleia gabbro body are mainly of mafic composition. The three dates, one from the Holleia gabbro (1507 $\pm 6 \mathrm{Ma}$, Fig. 8k, BBI106) and two from its foliated host rock (1501 $\pm 6 \mathrm{Ma}$, Fig. 9f, quartz dioritic gneiss BBI141 and 1509 \pm 7 Ma, Fig. 8j, granodioritic boudin BBI144) are equivalent. They indicate that the Holleia gabbro and its host rock are part of one event of plutonic to volcanic mafic magmatism, at c. $1505 \mathrm{Ma}$.

\subsubsection{BBI17, coarse foliated granite, western Kongsberg Complex}

The Vatnås granitic gneiss is a c. $1.5 \mathrm{~km}$ thick, rather homogeneous, red foliated granite, with a steep N S trending foliation (Fig. 5). Jacobsen and Heier (1978) describe the granite as intrusive into the gneiss sequence. However, we could not document any crosscutting relationships. Sample BBI17 is a garnet bearing peraluminous musco vite granitic gneiss from this lithodeme. Zircon is rich in $\mathrm{U}$ (340 $1410 \mathrm{ppm}$ ) and characterized by a weak CL signal (dark CL) and weak prismatic zoning. Five zircon $\mathrm{U} \mathrm{Pb}$ analyses are widely discordant (attributed to metamictization) and eight of the remaining analyses yield a precise age of $1505 \pm 4$ Ma (Fig. 81, SIMS data, ${ }^{207} \mathrm{~Pb} /{ }^{206} \mathrm{~Pb}$ age, $\mathrm{n}=8, \mathrm{MSWD}=0.80, \mathrm{Th} / \mathrm{U}=0.36$ ) for magmatic crystallization of the protolith. This age is older than the 6 point whole rock $\mathrm{Rb} \mathrm{Sr}$ errorchron age of $1354 \pm 66 \mathrm{Ma}$ $\left({ }^{87} \mathrm{Sr} /{ }^{86} \mathrm{Sr}\right.$ initial $\left.=0.7068\right)$ re calculated from data by Jacobsen and Heier (1978).

\subsubsection{BBI06, garnet bearing leucogneiss layer, western Kongsberg Complex}

At the sampling locality (Fig. 5), a rather homogeneous, amphibole biotite bearing granodioritic gneiss with near vertical attitude hosts a c. $50 \mathrm{~cm}$ leucogneiss layer, with sharp conformable contacts. The leucogneiss contains garnet and was collected to bracket the local timing of migmatitization or metamorphism, unfortunately without success. Sample BBI06 contains zircon with weak CL signal (dark CL), and perceptible oscillatory zoning. A group of concordant analyses yield an intrusion age of $1504 \pm 5 \mathrm{Ma}$ for the protolith of this leucogneiss layer (Fig. 9a, SIMS data, ${ }^{207} \mathrm{~Pb} /{ }^{206} \mathrm{~Pb}$ age, $\mathrm{n}=11$, MSWD $=1.6, \mathrm{Th} / \mathrm{U}=$ 0.36). This age probably represents a minimum age for the hosting granodioritic gneiss. One analysis of a tip with dark CL signal yields a much younger age of $1156 \pm 26 \mathrm{Ma}$ (Fig. $9 \mathrm{~b},{ }^{207} \mathrm{~Pb} /{ }^{206} \mathrm{~Pb}$ age). This analysis is characterized by a high $\mathrm{U}$ content (322 ppm) and high $\mathrm{Th} / \mathrm{U}$ ratio $(0.86)$. The high $\mathrm{Th} / \mathrm{U}$ ratio is atypical of metamorphic zircon in an epidote bearing paragenesis. Little confidence is placed in this isolated analysis to date metamorphism at the locality.

\subsubsection{BBI103, granodioritic gneiss, western Kongsberg Complex}

This is a heterogeneous, steeply dipping, granodioritic gneiss unit (Fig. 5), weakly to strongly layered and banded, variably migmatitic and characterized by garnet blastesis. The gneiss trends NNE SSW and it was sampled to date anatexis. The sample contains leucosome veins. It is inequigranular with phenoblasts of amphibole, plagioclase, allanite and garnet, a few millimetre thick, in a fine grained foliated matrix. It is unclear whether the protolith is a phenocryst bearing volcanic rock, namely a dacite, or if the fine grained nature of the matrix is the pro duct of intense deformation. Zircon is fractured, rich in inclusions, prismatic, oscillatory zoned and commonly shows a metamorphic rim. Eleven analyses of non fractured oscillatory zoned zircon yield an age of $1503 \pm 6 \mathrm{Ma}$ (Fig. 9c, SIMS data, ${ }^{207} \mathrm{~Pb} /{ }^{206} \mathrm{~Pb}$ age, $\mathrm{n}=$ 11 , MSWD $=0.86, \mathrm{Th} / \mathrm{U}=0.36$ ), recording the magmatic crystallization of the volcanic or plutonic protolith. Only one rimappeared to be large enough to be reliably analysed. It yields an age of $1140 \pm 33$ Ma (Fig. 9d), with a low Th/U ratio (0.09) typical for amphibolite facies metamorphism. This rim is interpreted to date amphibolite facies me tamorphism or migmatitization.

\subsubsection{BBI19, granodioritic gneiss, western Kongsberg Complex}

Sample BBI19 is from a c. $500 \mathrm{~m}$ thick, rather homogeneous, granodioritic orthogneiss exposed near the Skollenborg train station (Fig. 5), and situated some $35 \mathrm{~km}$ along strike southwards of the previously described sample (BBI17) of the Vatnås granitic gneiss (Jacobsen and Heier, 1978). The gneiss commonly exhibits an augen texture $(1 \mathrm{~cm} \mathrm{~K}$ feldspar augen) and flattened microdioritic enclaves. Zircon has a core with oscillatory zoning and a rim characterized by embayements to wards the core. These two domains, however, probably formed during two events very close in age, as $\mathrm{U} \mathrm{Pb}$ analyses of the rim are coeval with those of the core. Twelve analyses in the core and rim yield an age of $1502 \pm 6$ Ma (Fig. 9e, SIMS data, ${ }^{207} \mathrm{~Pb} /{ }^{206} \mathrm{~Pb}$ age, $\mathrm{n}=12$, MSWD $=$ $0.71, \mathrm{Th} / \mathrm{U}=0.38$ ), recording intrusion of the plutonic body. The 1502 $\pm 6 \mathrm{Ma}$ age is equivalent to the $1505 \pm 4 \mathrm{Ma}$ age of the Vatnås granitic gneiss (Jacobsen and Heier, 1978). On the basis of available field and geophysical data and these two dates, a layer of granitic granodioritic gneiss, c. $30 \mathrm{~km}$ long, attributed to this c. 1505 Ma magmatic event, can be mapped between the two sampled localities.

\subsubsection{BBI152, tonalitic gneiss, western Kongsberg Complex}

This sample is from a c. $2 \mathrm{~km}$ wide, NNE SSW trending, steeply dipping, tonalitic, quartz dioritic to dioritic gneiss (Fig. 5). The rock is variably layered and veined. The sampled outcrop is characterized by a homogeneous composition, garnet blastesis and a rusty alteration, characteristic of a sulfide bearing rock. The sample is a garnet bearing quartz dioritic to tonalitic gneiss. Zicon is stubby to prismatic. It contains a CL dark fractured core, generally largely metamict and porous, surrounded by a large CL dark sector zoned mantle, also rich in U (200 $<\mathrm{U}<630 \mathrm{ppm}$ ). Only one near concordant analysis of the core could be performed, yielding a ${ }^{207} \mathrm{~Pb} /{ }^{206} \mathrm{~Pb}$ age of $1560 \pm 13 \mathrm{Ma}(\mathrm{U}=435$ $\mathrm{ppm}, \mathrm{Th} / \mathrm{U}=0.41$ ). Analyses of the sector zoned mantle are partly discordant. A cluster of ten concordant analyses, however, yields an age of $1492 \pm 5 \mathrm{Ma}$ (Fig. 9g, SIMS data, ${ }^{207} \mathrm{~Pb} /{ }^{206} \mathrm{~Pb}$ age, $\mathrm{n}=10$, MSWD $=$ $1.6, \mathrm{Th} / \mathrm{U}=0.51$ ) for crystallization of the mantle. The in terpretation of results for this sample is subjective. The age of magmatic crystallization of the tonalite protolith of this gneiss could be attributed to the core, having a poorly estimated age of $1560 \pm 13 \mathrm{Ma}$, or to the large sector zoned mantle with an age of $1492 \pm 5 \mathrm{Ma}$. We prefer this last interpretation.

\subsubsection{BBI150, granitic granodioritic gneiss, western Kongsberg Complex}

A granitic to granodioritic gneiss unit, c. $3 \mathrm{~km}$ thick and $60 \mathrm{~km}$ long, follows the western boundary of the Modum Complex (Fig. 5), with a characteristic sigmoid orientation (successively NNE, NNW and NNE trending from south to north). It is clearly visible on the geophysical maps of the area, with a positive radioelement anomaly. An ID TIMS zircon age estimate of $1500 \pm 5 \mathrm{Ma}$ is published for one sample of amphibole bearing granodioritic gneiss (N95 66), known as the Veld stad gneiss (Fig. 5) (Bingen et al., 2005). Sample BBI150 is a foliated granite targeting the southern reaches of this gneiss unit in the Hokksund area (Fig. 5). In this area however, the bedrock is significantly affected by faulting and low temperature alteration related to formation of the Oslo Rift. The sample is therefore characterized by almost total chloritization of biotite and saussuritization of feldspar. It delivered only few small prismatic zircon crystals of poor quality. Zircon shows oscillatory zoning, including thin zones of clearly porous and metamict material. Seven SIMS analyses, carefully placed in CL bright, non 

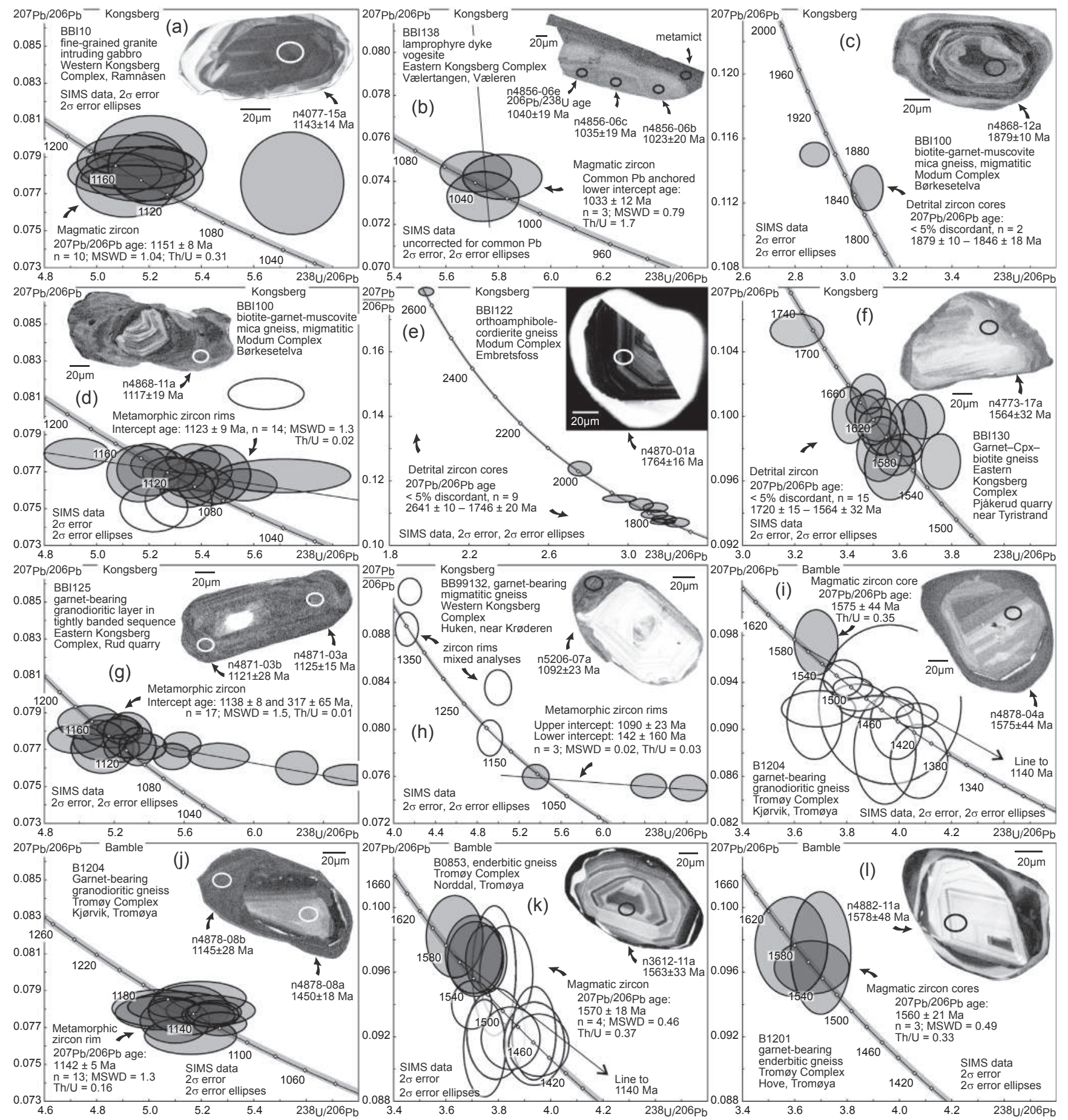

Fig. 10. Zircon $\mathrm{U}-\mathrm{Pb}$ data and selected $\mathrm{CL}$ images.

fractured and crystalline material, give a concordant cluster with an age of $1485 \pm 12 \mathrm{Ma}$ (Fig. 9h, SIMS data, ${ }^{207} \mathrm{~Pb} /{ }^{206} \mathrm{~Pb}$ age, $\mathrm{n}=7$, MSWD $=1.3, \mathrm{Th} / \mathrm{U}=0.31$ ). This age records intrusion of the protolith of the granite. One zircon xenocryst with a distinct sector zoning gives an age of $1548 \pm 26 \mathrm{Ma}$. The intrusion age of $1485 \pm 12 \mathrm{Ma}$ for sample BBI150 is nominally younger than the age of $1500 \pm 5$ Ma for the Veldstad gneiss, taken $40 \mathrm{~km}$ alongstrike, although the two ages formally overlap within error. This may suggest that the $60 \mathrm{~km}$ long gneiss unit represents more than one gneiss sheet. The foliated granite at $1485 \pm 12 \mathrm{Ma}$ is the youngest detected magmatic rock in Kongsberg that can be attributed to the Gothian Telemarkian events and it is followed by a long period of magmatic quiescence.

\subsection{Kongsberg Unit, small plutonic bodies, $11701030 \mathrm{Ma}$}

\subsection{1. ВВI04, BВI05, foliated granite granodiorite, western Kongsberg} Complex

The western part of the Kongsberg Complex hosts conformable sheets or layers, some of which are hundreds of metre thick, of fine grained, foliated, granite granodiorite, more homogeneous than the hosting gneiss complex. Sample BBI04 represents a biotite rich granodioritic layer. Sample BBI05 represents a more inequigranular and less foliated granitic layer, collected c. $200 \mathrm{~m}$ across strike (Fig. 5). Sample BBI04 contains a few small prismatic to xenomorphic zircon crystals with convolute zoning visible on CL images. The zircon is rich in $\mathrm{U}$ 
$(80<\mathrm{U}<950 \mathrm{ppm})$ and this zoning pattern suggests that the crystals were annealed/recrystallized sometime after their magmatic crystal lization. Analyses by SIMS define a discordia line with an upper inter cept age of $1167 \pm 12 \mathrm{Ma}$ (Fig. 9i, $\mathrm{n}=13$, MSWD $=1.00$, Th/U $=$ 0.27). Zircon crystals from sample BBI05 are prismatic, also rich in $U$ $(250<\mathrm{U}<1540 \mathrm{ppm})$ and show oscillatory growth zoning. Ana lyses by SIMS also define a discordia line with an upper intercept age of 1157 $\pm 10 \mathrm{Ma}$ (Fig. 91, $\mathrm{n}=9$, MSWD $=0.94, \mathrm{Th} / \mathrm{U}=0.30$ ). The two ages at $1167 \pm 12$ and $1157 \pm 10$ Ma overlap within error, and in dicate that the two samples are part of one or two closely related granite granodiorite sills that intruded into the older (1570 $1485 \mathrm{Ma}$ ) orthogneiss complex at around $1162 \mathrm{Ma}$. The nearby leucogneiss sample BBI06 attests to an age of $1504 \pm 5$ Ma for the hosting gneiss complex. The fine grained texture of the two samples suggests a subvolcanic intrusion possibly as sill(s).

\subsubsection{BBI01, granitic dyke in gabbro, western Kongsberg Complex}

Sample BBI01 is from a c. $100 \mathrm{~m}$ thick fine grained biotite bearing granite dyke or sill hosted in a medium grained weakly deformed me tagabbro. This gabbro is part of the c. $3 \mathrm{~km}$ wide Vinoren metagabbrobody (Fig. 5) (Jacobsen and Heier, 1978). The dyke or sill displays a sharp intrusive contact relative to the gabbro. Angular enclaves of gabbro are also observed inside the granite. Only 10 zircon crystals were recovered from the sample. Four analyses in prismatic oscillatory zoned zircon yield an intrusion age of $1164 \pm 12 \mathrm{Ma}$ (Fig. 9j, SIMS data, ${ }^{207} \mathrm{~Pb} /{ }^{206} \mathrm{~Pb}$ age, $\mathrm{n}=4$, MSWD $=2.3$, Th/ $\mathrm{U}=0.46$ ) for the crystallization of the granite. By inference, this age also represent a minimum age for the intrusion of the gabbro, in accordance with a 6 point whole rock $\mathrm{Rb} \mathrm{Sr}$ errorchron age of $1168 \pm 210 \mathrm{Ma}$ $\left({ }^{87} \mathrm{Sr} /{ }^{86} \mathrm{Sr}_{\text {initial }}=0.7025\right)$ recalculated from isotope data by Jacobsen and Heier (1978) on samples of the Vinoren gabbro. In nearby lo calities, the metagabbro, as well as the fine grained granite dykes, sills, and pods commonly contain garnet phenoblasts, implying that the 1164 $\pm 12 \mathrm{Ma}$ age is also a maximum age for regional metamorphism. Three analyses of zircon cores yield an age of $1505 \pm 18 \mathrm{Ma}$ (Fig. 9k, intercept age), documenting inheritance in the zircon population of the granite dyke.

\subsubsection{BBI10, granitic dyke in gabbro, western Kongsberg Complex}

Sample BBI10 is from a fine grained biotite bearing granitic dyke hosted in a medium grained metagabbro (Fig. 5). The dyke is un foliated, irregular, a few $\mathrm{m}$ thick, and it contains angular blocks of coarse gabbro. The dyke is mapped at the margin of a c. $300 \mathrm{~m}$ wide sill of granite entirely included inside the Vinoren metagabbro (Jacobsen and Heier, 1978). Oscillatory to sector zoned zircon define an age of $1151 \pm 8 \mathrm{Ma}$ (Fig. 10a, SIMS data, ${ }^{207} \mathrm{~Pb} /{ }^{206} \mathrm{~Pb}$ age, $\mathrm{n}=10$, MSWD $=$ $1.04, \mathrm{Th} / \mathrm{U}=0.31)$. The age of $1151 \pm 8$ Ma represents a minimum age for intrusion of the host Vinoren metagabbro, in ac cordance with the result from the equivalent sample BBI01.

\subsubsection{BBI138, lamprophyre dyke, eastern Kongsberg Complex}

An E W trending lamprophyre dyke was discovered along lake Væleren (Fig. 5). It crosscuts an heterogeneous N S trending gneiss complex dominated by a mylonitic, isoclinally folded, granitic gneiss, interlayered with mafic layers, and yielding an intrusion age of $1541 \pm$ 4 Ma (sample BBI134, Fig. 8f). The lamprophyre dyke has an irregular shape, is mappable for a maximum of $30 \mathrm{~m}$, and is up to $5 \mathrm{~m}$ thick. At the contact, there exists a fine grained, c. $10 \mathrm{~cm}$ thick, un foliated chilled margin associated with a sharp intrusive contact (Fig. 11f h). The contact crosscuts the mylonitic fabric in the gneiss with an angle of c. $70^{\circ}$. The chilled margin shows an isotropic (un foliated) subophitic texture, with a grain size of c. $1 \mathrm{~mm}$, including laths of amphibole and apatite in a groundmass of poikilitic $\mathrm{K}$ feldspar. The assemblage in the chilled margin classifies the lamprophyre as vogesite. The centre of the dyke is coarse grained, rich in chlorite, and it partly shows an internal crenulation and a foliation parallel to the margins of

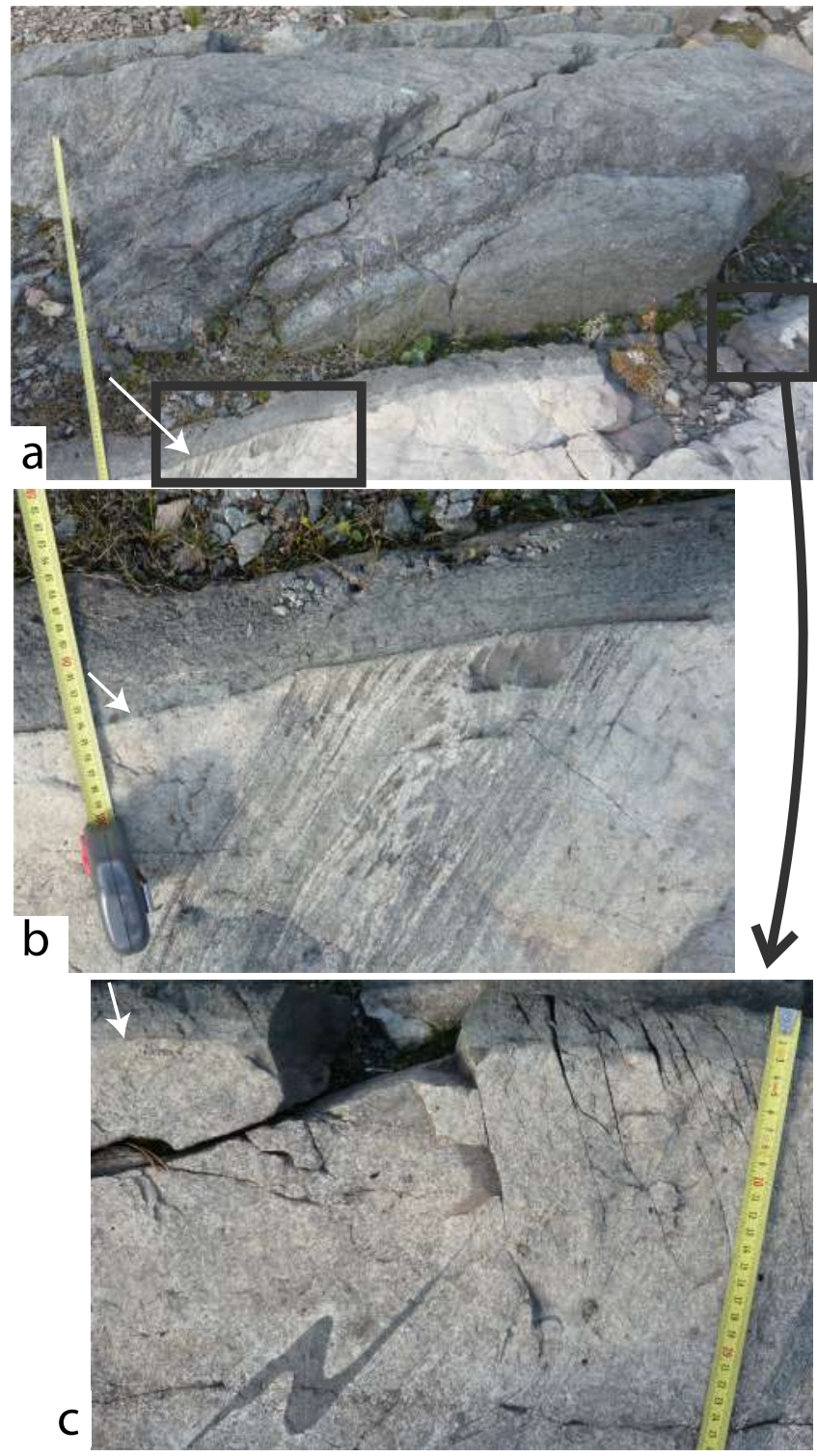

Fig. 11. Lamprophyre (vogesite) dyke in the Væleren area (Fig. 3) showing a chilled margin (white arrow) crosscutting the steep mylonitic fabric and isoclinal folds in the gneiss. The dyke yields an age of $1033 \pm 12 \mathrm{Ma}$ (Fig. 10b), providing a minimum age for deformation and formation of the fabric.

the dyke. The centre of the dyke contains coarse amphibole, chlorite, $\mathrm{K}$ feldspar, carbonate and epidote.

Sample BBI138 is from the middle part of the dyke. It provided abundant large prismatic zircon crystals, up to $400 \mu \mathrm{m}$ in length. However, zircon is rich in $\mathrm{U}$ and Th (generally more than $1000 \mathrm{ppm}$ ) and largely dark, porous and highly metamict. Only a few partly transparent crystals could be recovered. Six U Pb analyses were per formed in two sector zoned crystals. Three of these have U content lower than $470 \mathrm{ppm}$ and are concordant. These three analyses, un corrected for common $\mathrm{Pb}$ and anchored at a common $\mathrm{Pb}$ composition, define a lower intercept age in the Tera Wasserburg diagram at $1033 \pm 12 \mathrm{Ma}$ (Fig. 10b, SIMS data, $\mathrm{n}=3$, MSWD $=0.79$, Th/ $\mathrm{U}=1.7$ ). This age records magmatic crystallization of the zircon and therefore of the dyke.

\subsection{Kongsberg Unit, metasediments}

\subsubsection{BBI100, migmatitic mica gneiss, Modum Complex}

The sampling locality is situated along the western margin of the 
Modum Complex (Fig. 5). It consists of strongly foliated NNE SSW trending layered micagneiss, containing biotite, garnet and muscovite. Layers of coarser quartzofeldspathic gneiss are interpreted as leucosome. The sample contains rounded to xenomorphic zircon, characterized by a core rim structure. The detrital core is variably lumi nescent and oscillatory zoned. The rim is generally broad, characterized by low CL luminescence (CL dark), and concentric to patchy zoned. The rim is clearly crosscutting zoning in the core. It both replaces and overgrowth the core. The rim is rich in $\mathrm{U}(262<\mathrm{U}<1146 \mathrm{ppm})$, poor in $\mathrm{Th}(\mathrm{Th} / \mathrm{U}=0.02)$ and interpreted as metamorphic. Two SIMS $\mathrm{U} \mathrm{Pb}$ analyses of cores are nearly concordant at $1879 \pm 10$ and $1846 \pm 18 \mathrm{Ma}$ (Fig. 10c). Analyses of the rim are variably discordant. Fourteen of them define a discordia line with an upper intercept age of $1123 \pm 9 \mathrm{Ma}$ (Fig. $10 \mathrm{~d}$, MSWD $=1.3$ ), interpreted as the age of me tamorphism, which includes migmatitization.

\subsubsection{BBI122, orthoamphibole cordierite gneiss, Modum Complex}

An orthoamphibole cordierite gneiss layer is described at Embretsfoss (Fig. 5) (Munz, 1990; Munz et al., 1994) at the contact between a metagabbro body largely affected by albitization and a package of metasedimentary rocks including quartzite and micaschist. Sample BBI122 from this gneiss contains coarse gedrite, cordierite and tourmaline. It also contains rounded zircon characterized by a CL lu minescent rim. The rim crosscuts zoning in the core and defines inwards directed embayements. It can be classified as CL bright "surface con trolled alteration" following Vavra et al. (1999). The rim is so poor in U that it did not provide any significant $\mathrm{U} \mathrm{Pb}$ analysis. Nine zircon cores yield ${ }^{207} \mathrm{~Pb} /{ }^{206} \mathrm{~Pb}$ ages ranging from $2641 \pm 10$ to $1746 \pm 20 \mathrm{Ma}$ (Fig. $10 \mathrm{e}$ ). The scatter of ages implies that the zircon cores are detrital and by inference that the protolith for this metasomatic rock is part of the metasedimentary package exposed at Embretsfoss, as already sug gested by Munz (1990).

\subsubsection{BBI130, metagreywacke, eastern Kongsberg Complex}

A small quarry excavated perpendicularly to the regional NNE SSW trending steep foliation, exposes a layered felsic gneiss rich in coarse garnet and biotite (Fig. 5). This rock is interpreted as a metagreywacke or metapsammite affected by migmatitization. A layered dioritic gneiss, containing a granulite facies garnet clinopyroxene assemblage repla cing-amphibole, is also exposed. Sample BBI130 is a garnet biotiteclinopyroxene gneiss of intermediate composition, collected from the layered felsic gneiss. The abundance of clinopyroxene implies that the rock is calcic and transitional towards a calc silicate gneiss. Zircon crystals are coarse, prismatic to rounded, and display variably planar oscillatory zoning. They do not contain rims of metamorphic origin. Fifteen concordant to near concordant $\mathrm{U} \mathrm{Pb}$ analyses were collected in the centre of 15 crystals. The ${ }^{207} \mathrm{~Pb} /{ }^{206} \mathrm{~Pb}$ age ranges from $1720 \pm 15$ to $1564 \pm 32 \mathrm{Ma}$ (Fig. 10f). The dispersion of dates indicate that zircon is detrital, and therefore that the sample is indeed a clastic metasedimentary rock, deposited after $1564 \pm 32 \mathrm{Ma}$.

\subsubsection{BBI125, banded gneiss, eastern Kongsberg Complex}

A N S trending, vertical, tightly banded gneiss sequence is exposed in the $300 \mathrm{~m}$ long, E W trending wall of a gravel quarry north of Vikersund (in Rud; Fig. 5). The banded gneiss consists of straight, near vertical, layers, between 5 and $50 \mathrm{~cm}$ thick, with contrasted felsic, in termediate and mafic compositions. Some coarse felsic layers are in terpreted as leucosome. A rare red calc silicate layer is found. The banded gneiss is characterized by pervasive garnet blastesis and amphibolite facies metamorphism. The rock package is interpreted as a high strain zone. Sample BBI125 was collected from a grey layer of granodioritic composition. Zircon crystals are rounded to elongate, commonly fractured. They commonly show a CL bright core interpreted as a residual detrital or magmatic core, surrounded by a broad CL dark mantle characterized by weak concentric zoning. The mantle is rich in $\mathrm{U}$ $(500<\mathrm{U}<910 \mathrm{ppm})$, poor in $\mathrm{Th}$, and consequently has a low $\mathrm{Th} /$
$\mathrm{U}$ (0.01) typical for amphibolite facies metamorphism. SIMS $\mathrm{U} \mathrm{Pb}$ analyses of the mantle define a discordia line with an upper intercept age of $1138 \pm 8 \mathrm{Ma}$ and a lower intercept of $317 \pm 65 \mathrm{Ma}$ (Fig. 10g, $\mathrm{n}$ $=17$, MSWD $=1.5$ ). The upper intercept at $1138 \pm 8 \mathrm{Ma}$ is inter preted as the age of metamorphism, which includes migmatitization at this locality.

\subsubsection{B99132, garnet bearing migmatitic gneiss, western Kongsberg} Complex

A gneiss unit characterized by abundant partial melting and per sistent garnet blastesis is exposed near lake Krøderen in the western part of the Kongsberg Complex (Fig. 5). Sample BB99132 is made up of garnet biotite amphibole bearing gneiss of granitic to granodioritic composition, rich in thin centimetre scale leucosome layers. Garnet phenoblasts can be up to $2 \mathrm{~cm}$ in diametre. The sample was collected to date migmatitization and contains both leucosome and mesosomelayers. Zircon crystals are commonly fractured and show a core rim structure, with a CL bright oscillatory zoned core contrasting with a CL dark patchy to concentric zoned rim. Only the rim was targeted and only seven SIMS analyses could be safely placed between fractures. Four of rim analyses are moderately rich in U (240 $<\mathrm{U}<530 \mathrm{ppm})$. They scatter between $1419 \pm 19$ and $1188 \pm$ $18 \mathrm{Ma}$ and probably represent mixture of core and rim material. The three last rim analyses are rich in $\mathrm{U}(1100<\mathrm{U}<1400 \mathrm{ppm})$, poor in $\mathrm{Th}(\mathrm{Th} / \mathrm{U}=0.03)$, and represent metamorphic neoformed zircon. They yield a discordia line with an upper interceptage of $1090 \pm 23$ Ma (Fig. 10h). This estimate is not entirely reliable. It is tailing other estimates of the age of meta morphism inside the Kongsberg Unit.

\subsection{Bamble Unit, enderbite Tromøy Complex}

In this study, we specifically address the controversial geochronology of the enderbitic Tromøy Complex, located in the core of the granulite facies domain on the Island of Tromøy in coastal Bamble (Andersen et al., 2004a; Cooper and Field, 1977; Field et al., 1980; Knudsen and Andersen, 1999). The Tromøy Complex (Fig. 3; Fig. 7) consists of noritic, enderbitic and trondhjemitic gneisses characterized by low $\mathrm{K}$ calc alkaline signature and depletion in large ion lithophile elements (LILE) and other incompatible elements (Cooper and Field, 1977; Field et al., 1980; Knudsen and Andersen, 1999). It was considered as a typical example of depleted lower continental crust, formed by residual granulites or cumulates (Rudnick and Presper, 1990). The low abundance in incompatible elements, including $\mathrm{Zr}$, however, has been an obstacle to standard geochronological investigations. We successfully recovered zircon from seven samples (Fig. 7).

\subsubsection{B1204, garnet bearing granodioritic gneiss, Tromøy Complex}

The outcrop is made of garnet bearing granodioritic gneiss with good folition, weak compositional layering, and centimetric leucosome veins parallel to foliation (Fig. 7). Sample B1204 is a K feldspar bearing amphibole garnet gneiss, and therefore not a granulite. Zircon is rounded to xenomorphic and displays a nice core rim structure. The core is oscillatory zoned, variably fractured and variably rich in in clusions. It is separated from the thick dark CL, concentric zoned, rim, by a thin CL bright interface. Analyses of the core scatter along the concordia curve between $1575 \pm 44$ and $1365 \pm 55$ Ma (Fig. 10i, SIMS data, ${ }^{207} \mathrm{~Pb} /{ }^{206} \mathrm{~Pb}$ age, $\mathrm{n}=12, \mathrm{Th} / \mathrm{U}=0.39$ ). The oldest con cordant analysis at $1575 \pm 44 \mathrm{Ma}$ is interpreted as crystallization of the magmatic protolith of the rock, while younger analyses probably reflect partial Sveconorwegian resetting. Analyses of the rim and rounded concentrically zoned crystals define a robust cluster with an age of 1142 \pm 5 Ma (Fig. $10 \mathrm{j},{ }^{207} \mathrm{~Pb} /{ }^{206} \mathrm{~Pb}$ age, $\mathrm{n}=13, \mathrm{MSWD}=1.3, \mathrm{Th} / \mathrm{U}=$ 0.16 ), attributed to metamorphism and probably partial melting at this locality. 


\subsubsection{B0853, enderbitic gneiss, Tromøy Complex}

Sample B0853 is from an homogeneous exposure of two pyroxene, amphibole bearing enderbite (Fig. 7, no K feldspar present). The out crop contains no pervasive planar or linear fabric. The zircon population is made of small rounded oscillatory zoned crystals, showing a thin luminescent rim. The rim could not be analysed separately. A total of 14 analyses were performed in the core and they spread along the concordia curve between $1590 \pm 39$ and $1452 \pm 51$ Ma (Fig. 10k, SIMS data, ${ }^{207} \mathrm{~Pb} /{ }^{206} \mathrm{~Pb}$ age, $\mathrm{n}=14, \mathrm{Th} / \mathrm{U}=0.37$ ). The four oldest con cordant analyses yield an average age of $1570 \pm 18$ Ma (Fig. 10k, $\mathrm{n}=$ $14, \mathrm{MSWD}=0.46, \mathrm{Th} / \mathrm{U}=0.37$ ). They are interpreted to corre spond to the crystallization of the magmatic protolith of the rock, while the other analyses probably reflect partial Sveconorwegian resetting.

\subsubsection{B1201, enderbitic gneiss, Tromøy Complex}

The outcrop consists of an isoclinally folded gneiss including amphibole rich mafic layers and heterogeneous felsic layers variably en riched in garnet (up to $1 \mathrm{~cm}$ rounded phenoblasts). Trondhjemitic leucosomes ( $<10 \mathrm{~cm}$ thick) hosting orthopyroxene phenoblasts (up to 2 cm long), similar to those described in Kullerud and Dahlgren (1993, their Fig. 3) or Knudsen and Andersen (1999, their Fig. 3a) are prominent in the mafic layers. Sample B1201 is from a felsic layer with clear foliation defined by pyroxene rich stripes. The rock is an anhy drous two pyroxene, garnet, oxide bearing enderbite, lacking any sign of post granulite facies retrogression. Zircon is xenomorphic and ex hibits a complex core rim texture. The core includes larges domains of patchy zoned, fractured, presumably metamict zircon with low CL signal and some minor domains with oscillatory zoned moderate to bright CL signal. Three analyses in this oscillatory zoned magmatic material gives a age of $1560 \pm 21 \mathrm{Ma}$ (Fig. 10l, SIMS data, ${ }^{207} \mathrm{~Pb} /{ }^{206} \mathrm{~Pb}$ age, $\mathrm{n}=3$, MSWD $=0.49$, Th/U $=0.33$ ). The metamorphic rim is commonly thick and characterized by a dark CL signal and concentric to sector zoning. The interface between core and rim is commonly marked by a CL bright seam. Analyses in the rim and some con centrically zoned crystals define an age of $1137 \pm 17$ Ma for meta morphism with some scatter (Fig. $12 \mathrm{a},{ }^{207} \mathrm{~Pb} /{ }^{206} \mathrm{~Pb}$ age, $\mathrm{n}=7$, MSWD $=3.3$, over dispersion of data, $\mathrm{Th} / \mathrm{U}=0.10)$.

\subsubsection{B0852, enderbitic gneiss, Tromøy Complex}

The locality exhibits a layered enderbitic gneiss (Fig. 7). Felsic layers, interpreted as leucosome, show garnet phenoblasts up to $1 \mathrm{~cm}$ in diameter. The sample contains a weak fabric, and it is a two pyroxene granulite lacking garnet and $\mathrm{K}$ feldspar but containing some biotite. Rounded zircon crystals $(<150 \mu \mathrm{m})$ show a dominant oscillatory zoned core. A thin CL dark sector zoned rim is commonly, but not system atically, observed, and it is separated from the core by a seam of CL bright zircon. Analyses of the oscillatory zoned core yield an age of $1550 \pm 8 \mathrm{Ma}$ (Fig. 12b, SIMS data, ${ }^{207} \mathrm{~Pb} /{ }^{206} \mathrm{~Pb}$ age, $\mathrm{n}=$ 13 , MSWD $=1.3, \mathrm{Th} / \mathrm{U}=0.35$ ) recording crystallization of the magmatic protolith of the gneiss. Four analyses of the metamorphic rim from two crystals record an age of $1147 \pm 18$ Ma (Fig. 12c, ${ }^{207} \mathrm{~Pb} /{ }^{206} \mathrm{~Pb}$ age, $\mathrm{n}=4, \mathrm{MSWD}=1.2, \mathrm{Th} / \mathrm{U}=0.31$ ).

\subsubsection{B0855, trondhjemitic gneiss, Tromøy Complex}

Sample B0855 is from an exposure of dominantly felsic gneiss with isoclinally folded mafic layers up to $20 \mathrm{~cm}$ in thickness (Fig. 7). The sample is a quartz rich trondhjemite with a weak foliation. The mafic minerals mainly consist of magnetite, ilmenite and orthopyroxene. Zircon is rounded to xenomorphic. It shows a core rim texture, with a patchy zoned porous and metamict core characterized by low CL signal (CL dark). The rim is variably thick, sector zoned and also character ized by a low CL signal (CL dark). Some crystals are made entirely of sector zoned, low CL material similar to the one of the rim. Analyses collected in the core, but one, are discordant. The concordant analysis is the oldest and gives a ${ }^{207} \mathrm{~Pb} /{ }^{206} \mathrm{~Pb}$ age of $1544 \pm 14 \mathrm{Ma}$ (Fig. 12d, SIMS data, $\mathrm{Th} / \mathrm{U}=0.36$ ), interpreted as the crystallization of the protolith of the gneiss. The analyses in the rim and sector zoned crystals are concordant and define a good cluster with an age of $1132 \pm 6 \mathrm{Ma}$ (Fig. 12e, SIMS data, ${ }^{207} \mathrm{~Pb} /{ }^{206} \mathrm{~Pb}$ age, $\mathrm{n}=14$, MSWD $=1.08$ ), interpreted to date the metamorphism in this rock. The low $\mathrm{Th} / \mathrm{U}$ ratio of 0.05 for this material is consistent with a metamorphic crystallization, in association with monazite, which is present in the sample.

\subsubsection{B1205, garnet biotite gneiss, Tromøy Complex}

The sampled outcrop is dominated by a typical grey enderbite gneiss, but it also contains a garnet bearing gneiss, with trondhjemitic veins that can be interpreted as leucosome. Sample B1205 is from the garnet biotite gneiss containing garnet phenoblasts up to $5 \mathrm{~mm}$ in diameter. Rare zircon forms rounded crystals smaller than $100 \mu \mathrm{m}$, characterized by very nice radial sector zoning. This zoning is typical for growth associated with granulite facies metamorphism (Pidgeon et al., 2000; Vavra et al., 1996). Seven analyses in such zircon give an age of $1147 \pm 12 \mathrm{Ma}$ (Fig. 12f, SIMS data, ${ }^{207} \mathrm{~Pb} /{ }^{206} \mathrm{~Pb}$ age, $\mathrm{n}=7$ MSWD $=0.38$, Th/ $=0.42$ ).

\subsubsection{B1202, enderbitic gneiss, Tromøy Complex}

Sample B1202 is collected from a grey, homogeneous and only weakly foliated outcrop. The sample is a fine grained, anhydrous, two pyroxene enderbite. A few rounded zircon crystals smaller than $80 \mu \mathrm{m}$ were recovered from this rock. They are characterized by concentric zoning and rather bright CL signal. Some crystals show a flat base, suggesting that they grew in contact with ilmenite or magnetite as described in Bingen et al. (2001a). Analyses in 14 crystals yield an age of $1144 \pm 9 \mathrm{Ma}$ (Fig. $12 \mathrm{~g}$, SIMS data, ${ }^{207} \mathrm{~Pb} /{ }^{206} \mathrm{~Pb}$ age, $\mathrm{n}=14$, $\mathrm{MSWD}=1.4, \mathrm{Th} / \mathrm{U}=0.20$ ), recording metamorphism in the rock. No pre-metamorphic core can be ascertained.

\subsection{Bamble Unit, charnockite augen gneiss, $11701140 \mathrm{Ma}$}

\subsubsection{B1206, Gjeving charnockite augen gneiss}

The c. $4 \mathrm{~km}$ wide and $15 \mathrm{~km}$ long Gjeving orthogneiss, in coastal Bamble (Fig. 7), is a lithodemic unit consisting of a grey green orthopyroxene bearing charnockite, grading into a red granitic augen gneiss without orthopyroxene. A zircon $\mathrm{U}$ Pb age of $1152 \pm 2$ Ma (ID TIMS data) is reported for the charnockite facies (Kullerud and Machado, 1991). Published Sm Nd mineral data define errorchrons scattering between $1201 \pm 52$ and $1068 \pm 51$ Ma (Kullerud and Dahlgren, 1993). A new sample, B1206, was collected in Dypvåg in an homo geneous, weakly foliated, coarse grained $(1 \mathrm{~cm})$, equigranular char nockite, showing brown orthopyroxene in outcrop interpreted to be magmatic. The sample contains abundant, coarse (up to $300 \mu \mathrm{m}$ ), prismatic magmatic zircon. Analyses by LA ICP MS yield an intrusion age of 1152 $\pm 11 \mathrm{Ma}$ (Fig. $12 \mathrm{~h},{ }^{207} \mathrm{~Pb} /{ }^{206} \mathrm{~Pb}$ age, $\mathrm{n}=16$, MSWD $=0.77$ ), equivalent to the previous age estimate.

\subsubsection{B1207, Ubergsmoen augen gneiss}

The Ubergsmoen augen gneiss (Fig. 7) is a, $1 \mathrm{~km}$ wide and $20 \mathrm{~km}$ long, lithodeme consisting of amphibolite facies granitic granodioritic augen gneiss, showing only local relics of charnockite (Nijland and Senior, 1991; Touret, 1967; Touret, 1971a; Touret and Falkum, 1987). An unpublished $\mathrm{Rb} \mathrm{Sr}$ whole rock isochron (Hagelia quoted in Nijland and Senior, 1991) indicates an age of $1143 \pm 30$ Ma for the plutonic event. A new sample, B1207, of coarse grained augen gneiss, rich in garnet and amphibole, was collected from an homogeneous outcrop with steep foliation. Abundant zircon forms large prismatic to rounded crystals (up to $300 \mu \mathrm{m}$ ). Magmatic oscillatory to sector zoning is partly overprinted by a convolute zoning characterized by inwards directed zones with very bright cathodoluminescence. The CL bright zones were not analysed (low U content leading to large error). Analyses of the oscillatory to sector zoned zircon yield an age of $1150 \pm 13 \mathrm{Ma}$ for the plutonic crystallization (Fig. 12i, SIMS data, ${ }^{207} \mathrm{~Pb} /{ }^{206} \mathrm{~Pb}$ age, $\mathrm{n}=10$, MSWD $=0.65, \mathrm{Th} / \mathrm{U}=0.47$ ). 

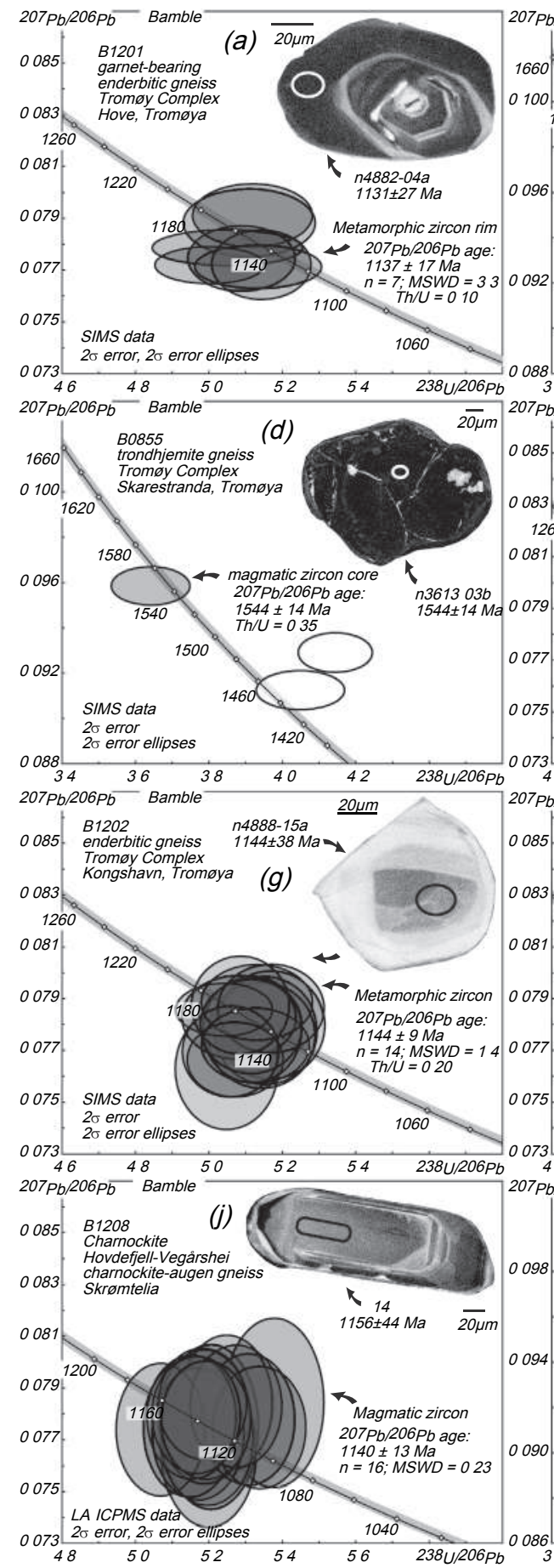
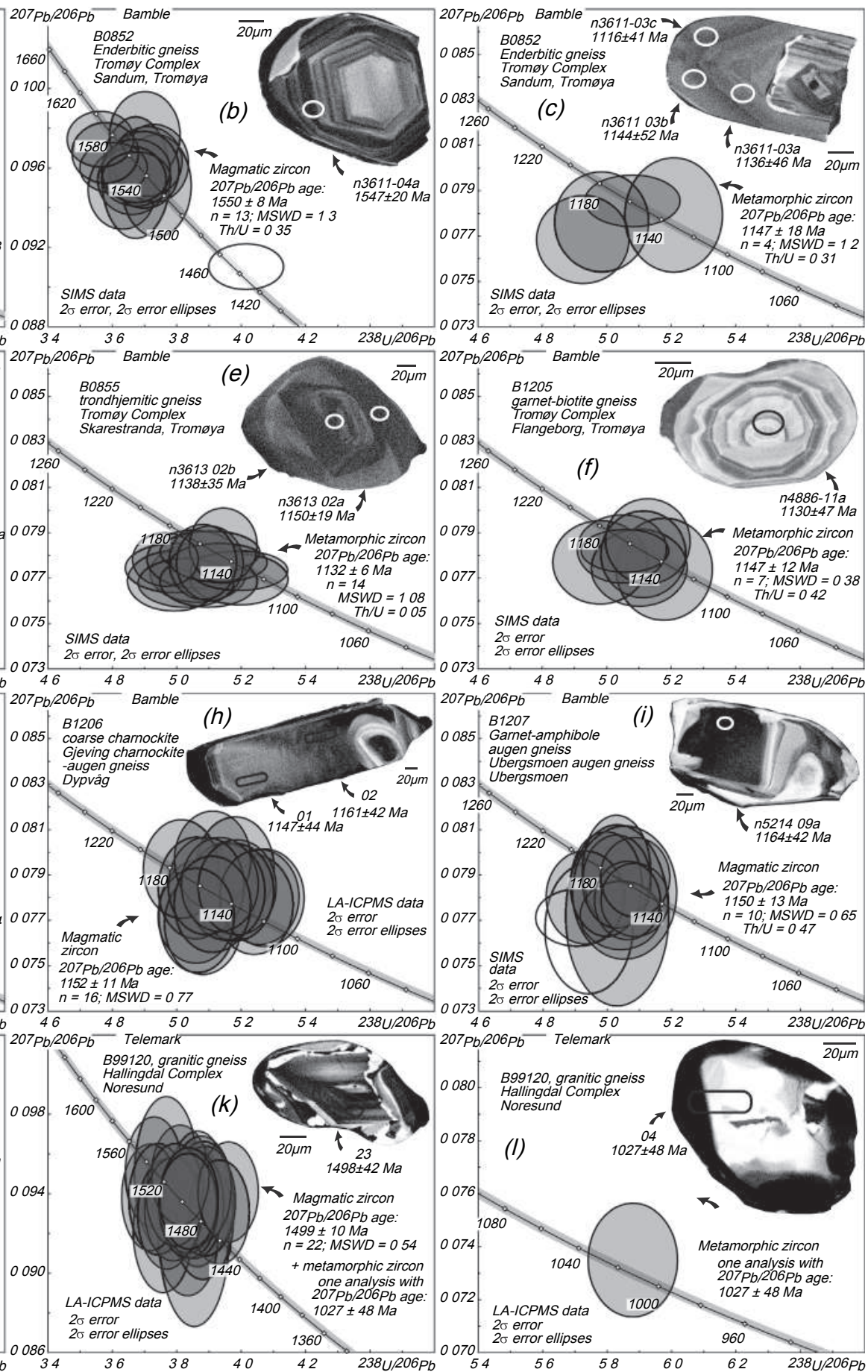

Fig. 12. Zircon $U-P b$ data and selected $C L$ images.

\subsubsection{B1208, Hovdefjell charnockite augen gneiss}

The Hovdefjell Vegårshei orthogneiss is a SW NE trending, c. $20 \mathrm{~km}$ long, lithodeme, exposed shortly to the southeast of the Kristiansand Porsgrunn Shear Zone. It contains three main facies (Touret, 1967; Touret, 1987): a weakly foliated charnockite in the southwest of the unit around Hovdefjell summit, a dominant biotite \pm amphibole \pm garnet augen gneiss occurring at the margin of the unit and towards the $\mathrm{NE}$, and a mylonitic to ultramylonitic facies, mainly forming thin shear zones along the northwestern margin along the Kristiansand Porsgrunn Shear Zone. An unpublished zircon $\mathrm{U} \mathrm{Pb}$ ages of $1168 \pm 2 \mathrm{Ma}$ is reg ularly quoted for intrusion of the Hovdefjell charnockite (Råheim and Krogh cited in Field et al., 1985). Sample B1208 is a grey green coarse charnockite, collected in an homogeneous outcrop with a weak fabric in the southwest part of the unit. Abundant large, up to $400 \mu \mathrm{m}$, prismatic zircon crystals show oscillatory growth zoning, sector zoning and convolute zoning. Sixteen analyses by LA ICP MS in these three types of zones yield a single age population with an average value of $1140 \pm 13 \mathrm{Ma}$ (Fig. $12 \mathrm{j},{ }^{207} \mathrm{~Pb} /{ }^{206} \mathrm{~Pb}$ age, $\mathrm{n}=16$, MSWD $=0.23$ ) in terpreted as recording the magmatic intrusion of the charnockite.

\subsection{Telemarkia Unit, orthogneisses and magmatic rocks}

3.6.1. B99120, biotite granitic gneiss, Hallingdal Complex

The Hallingdal Complex occupies the Telemarkia footwall of the 
Kongsberg Unit (west of the Saggrenda Sokna Shear Zone; Figs. 3 and 5). It comprises interlayered quartzite and biotite granitic gneiss. One sample of coarse quartzite published in Bingen et al. (2001b) is characterized by Paleoproterozoic and Archaean detrital zircon populations. The youngest analyzed detrital zircon gave a maximum deposition age for the sequence at $1716 \pm 16 \mathrm{Ma}$, opening the possibility that the Hallingdal Complex is Paleoproterozoic. Sample B99120 (Fig. 5) is from the biotite granitic gneiss, and was collected to test this idea. However, LA ICP MS analyses of zircon yield a good cluster of concordant points with an average age of $1499 \pm 10 \mathrm{Ma}$ (Fig. $12 \mathrm{k},{ }^{207} \mathrm{~Pb} /{ }^{206} \mathrm{~Pb}$ age, $\mathrm{n}=22$, MSWD $=0.54$ ). This age is interpreted to date intrusion of the granite precursor of the orthogneiss. The age of $1499 \pm 10 \mathrm{Ma}$ is ty pical for orthogneisses in the Telemarkia Unit, and therefore fails to substantiate a pre $1500 \mathrm{Ma}$ orthogneiss basement or a pre 1500 Ma deposition for the quartzite. Two additional analyses yield much younger ages. The youngest concordant analysis collected in a rounded zircon crystal with convolute zoning gives a ${ }^{207} \mathrm{~Pb} /{ }^{206} \mathrm{~Pb}$ age of $1027 \pm 48 \mathrm{Ma}$ (Fig. 121), interpreted to record amphibolite facies overprint. This is consistent with $1014 \pm 1 \mathrm{Ma}$ age from small rounded metamorphic zircon collected a nearby amphibolite body (sample B99130; Bingen et al., 2008b).

\subsubsection{B0922, B0906, granitic gneiss, Vråvatn Complex}

Northwest of the Bamble Telemarkia boundary zone, the Telemarkia Unit exposes a c. $60 \times 120 \mathrm{~km}$ gneiss complex, referred to as the South Telemark Gneisses by Andersen et al. (2007). It is domi nated by amphibolite facies, moderately to weakly foliated, NE SW trending, monotonous granitic gneiss and granite, locally migmatitic. This complex is poorly mapped. Available data, however, suggest dominant 12201190 Ma plutonic rocks, named in different areas Drivheia gneiss (Heaman and Smalley, 1994) and Vråvatn Complex (Andersen et al., 2007) (Fig. 3). Two samples of this complex were collected. Sample B0922 is from a large, flat lying, heterogeneous outcrop near Gongfjell. The apparently oldest lithology in the outcrop is a weakly layered granitic to granodioritic gneiss with $\mathrm{K}$ feldspar augen. This gneiss is interlayered with minor, isoclinally folded amphibolite, and intruded by several generations of aplite and pegmatite, ranging from conformable boudin to crosscutting dyke. The outcrop is locally migmatitic. Sample B0922 represents the amphibole bearing grano dioritic augen gneiss. Zircon crystals show a prismatic, oscillatory zoned core attributed to the crystallization of the granite protolith surrounded by two thin rims, a CL bright inner rim and a thin CL dark outer rim, attributed to metamorphism and migmatitization. Analyses of the core yield an age of $1210 \pm 12 \mathrm{Ma}$ (Fig. 13a, LA ICPMS data,

${ }^{207} \mathrm{~Pb} /{ }^{206} \mathrm{~Pb}$ age, $\mathrm{n}=15, \mathrm{MSWD}=0.44$ ) dating intrusion of the pro tolith and providing a maximum age for the migmatitization. Analyses of the rim could not be collected safely, leaving the age of migmatiti zation unconstrained.

Sample B0906 is a homogeneous orthogneiss of the Vråvatn Complex, well exposed along the shores of Flåvatnet. It represents a c. $20 \mathrm{~km}$ wide body of granitic granodioritic gneiss, commonly exhibiting an augen texture and a weak compositional layering. The sample itself is an amphibole bearing augen gneiss. Oscillatory zoned prismatic zircon records the age of intrusion of the protolith at $1207 \pm 7$ Ma (Fig. 13b, ${ }^{207} \mathrm{~Pb} /{ }^{206} \mathrm{~Pb}$ age, $\mathrm{n}=14$, MSWD $=1.2$ ).

\subsubsection{B0920, granitic gneiss, Nissedal Complex}

The low grade Nissedal Complex is dominated by metabasalt and it is well delineated on radiometric maps by a negative anomaly (Fig. 3). It rests above the Vråvatn Complex, forming a syncline c. $35 \mathrm{~km}$ long and $10 \mathrm{~km}$ wide. The metabasalt is foliated and affected by epidote amphibolite facies metamorphism. At some localities, a fine grained subophitic texture is well preserved, implying non penetrative deformation. There, dykes and sills of fine grained granite clearly intrude the metabasalt along sharp contacts and they are themselves intruded by mafic doleritic dykes. Sample B0920 is collected from a $50 \mathrm{~m}$ thick sheet of gneissic amphibole biotite granite, itself cut by a $5 \mathrm{~m}$ thick mafic dolerite with subophitic texture. Sample B0920 contains pris matic oscillatory zoned zircon. Six U Pb analyses yield an age of $1196 \pm 6 \mathrm{Ma}$ (Fig. 13c, SIMS data, ${ }^{207} \mathrm{~Pb} /{ }^{206} \mathrm{~Pb}$ age, $\mathrm{n}=6$, MSWD $=0.30$ ), recording intrusion of the granite sheet. This age overlaps with the age of granitoids in the underlying Vråvatn Complex (Andersen et al., 2007; this work). The data imply that the metabasalts are older than $1196 \pm 6$ Ma. Alternatively, the mutual intrusive rela tions between mafic and felsic subvolcanic rocks can suggest that the metabasalts represent the mafic component of a bimodal mafic felsic magmatic event at c. 1220 $1190 \mathrm{Ma}$, including the Vråvatn Complex. At regional scale, basalts of the Nissedal Complex ( $\geq$ c. $1196 \mathrm{Ma}$ ) are possibly coeval with those of the Sæsvatn Valldal Complex ( $\leq$ c. 1260 Ma; Fig. 3) (Bingen et al., 2002; Brewer et al., 2004). However they are older than those of the Bandak Succession (c. 1150 Ma)(Laajoki et al., 2002; Spencer et al., 2014).

\subsubsection{B0945, granite porphyry, Korbu prospect, Kongsberg Telemark boundary}

The boundary between the Kongsberg and Telemarkia Units is localized within a belt of foliated gneissic granite, whose intrusion is dated between $1170 \pm 11$ and $1146 \pm 5$ Ma (Bingen et al., 2005; Scheiber et al., 2015). A prospect for molybdenum, called Korbu pro spect, is located within this granite belt. It is hosted in a $2 \mathrm{~km}$ long small body of foliated quartz and feldspar porphyry that intrudes metabasalt (Fig. 5). At the sampling locality, the porphyry is characterized by feldspar phenocrysts up to c. $1 \mathrm{~cm}$ long and by fluorite, garnet, mo lybdenite and other sulfide minerals. It contains a network of quartz veins, each between 1 and $3 \mathrm{~cm}$ thick. The sample is a biotite musco vite fluorite molybdenite porphyry. It contains rare, small, oscillatory zoned, prismatic zircon crystals, generally rich in $\mathrm{U}(60<\mathrm{U}<900 \mathrm{ppm})$ and characterized by a low CL signal (CL dark). Eight SIMS U Pb analyses define a discordia line with a lower intercept age of $326 \pm 92 \mathrm{Ma}$, recording episodic $\mathrm{Pb}$ loss, and an upper intercept age of $1174 \pm 11 \mathrm{Ma}$ (Fig. 13d, $\mathrm{n}=8$, MSWD $=0.57$, Th/ $\mathrm{U}=0.34$ ), recording magmatic crystallization of the porphyry. An inherited zircon xenocryst gives an age of $1501 \pm 17 \mathrm{Ma}$. The data demonstrate that the Korbu porphyry is a magmatically evolved, fluid/fluor rich, facies of the voluminous 1170 1146 Ma granite belt along the Kongsberg Telemark boundary zone (Scheiber et al., 2015)

\subsubsection{B0926, metarhyolite, Bandak Succession, Brunkeberg Formation}

The low grade Telemark stratiform rocks abut the gneissic Vråvatn Complex along a ENE WSW trending, NNW dipping contact, which is exposed along the shore of Seljordvatnet (Fig. 3) (Laajoki et al., 2002; Lamminen, 2011). The nature of this contact is controversial (Fig. 14). At the contact, the gneiss complex is overlain by a thin quartzite in terlayered with amphibolite, called Garborg quartzite, and a metarhyolite, some $500 \mathrm{~m}$ thick. The rhyolite itself is overlain by a quartzite, the Lifjell quartzite, along a contact decorated by conglomerate (Lamminen, 2011). Originally, the contact was mapped as stra tigraphic (Dons and Jorde, 1978) with the rhyolite attributed to the c. 1510 Ma Rjukan Group, overlying an older gneiss basement (Vråvatn Complex), and itself overlain by the Lifjell quartzite attributed to the Seljord Succession (Fig. 14a). However, this simple interpretation is not correct. The Vråvatn Complex only yields protolith ages between c. 1220 and 1190 Ma (Andersen et al., 2007; this work) and therefore apparently much younger than anticipated before. The Garborg quart zite layer has a detrital zircon age distribution characterized by a main peak at around $1500 \mathrm{Ma}$, similar to the one of sediments of the Bandak Succession (Lamminen, 2011). A rhyolite/porphyry, collected $10 \mathrm{~km}$ alongstrike west of Seljordvatnet, near Brunkeberg, gave an age of $1155 \pm 2 \mathrm{Ma}$ (Laajoki et al., 2002), instead of c. $1510 \mathrm{Ma}$ as antici pated for the Rjukan Group. Contrastingly, the overlying Lifjell quart zite has been shown to have a detrital zircon age distribution with a main peak around $1760 \mathrm{Ma}$ (Lamminen, 2011), similar to the ones of 

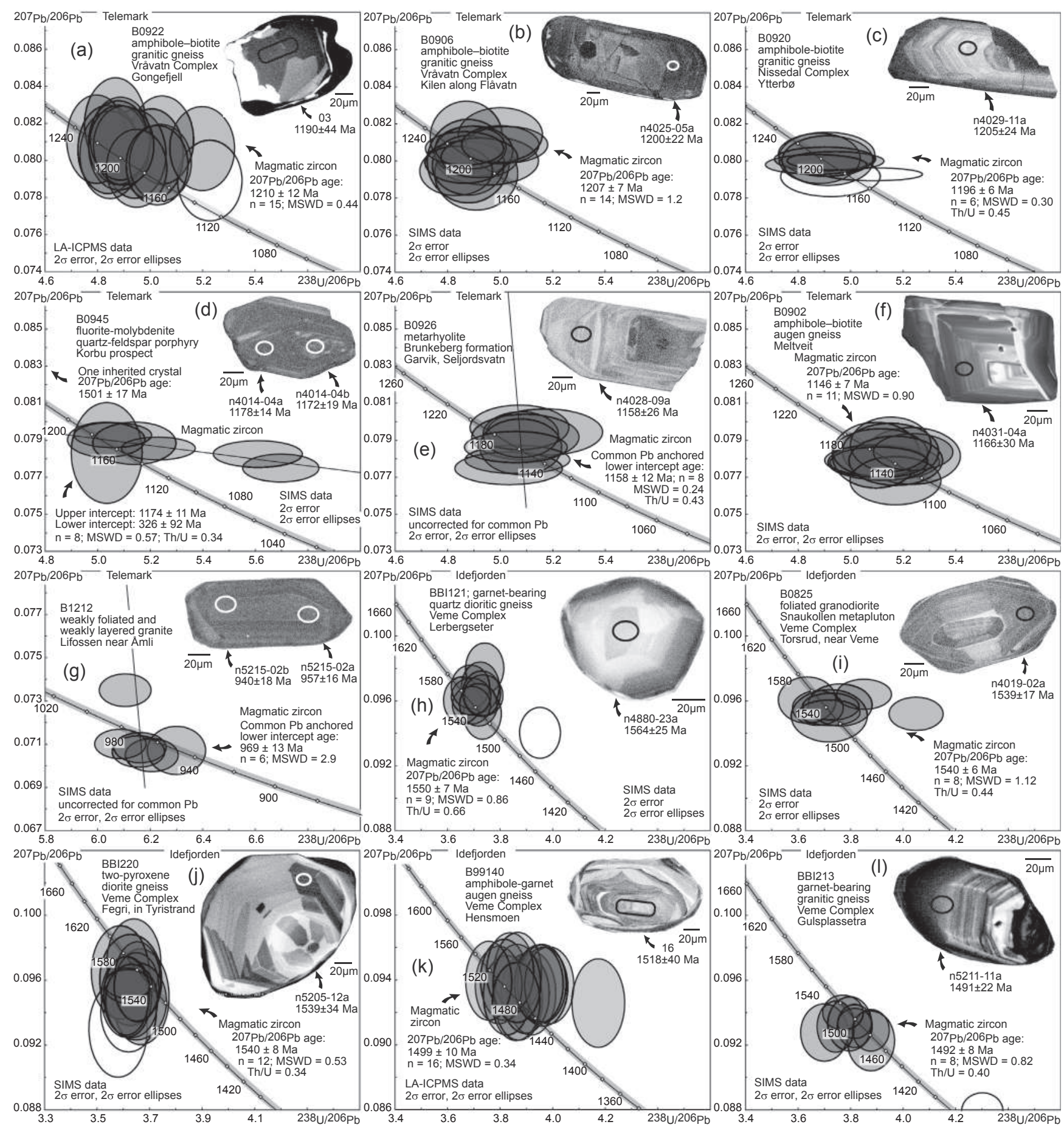

Fig. 13. Zircon U-Pb data and selected CL images.

the Seljord Succession. Therefore, both the Garborg quartzite and me tarhyolite are apparently tectonically overlain by older quartzite attributed to the Seljord Succession.

To further test this inverse relation, we collected the rhyolite along the shore of Seljordvatnet. Sample B0926 is a poorly deformed me tarhyolite with apparently preserved weak flow banding. The thin section shows recrystallized feldspar and quartz megacrysts some $35 \mathrm{~mm}$ long and smaller phenocrysts of oxide minerals, amphibole and zircon in a fine grained $(<50 \mu \mathrm{m})$ quartzofeldspathic groundmass. Metamorphic epidote, sphene and garnet are present. Towards the contact with the Lifjell quartzite, the metarhyolite is more intensely deformed ( $\mathrm{N}$ trending lineation) than in the centre of the unit where the sample is collected. The sample contains a few large prismatic, oscil latory zoned, zircon crystals up to $300 \mu \mathrm{m}$ long. Zircon contains common quartzofelspathic inclusions. Analyses, uncorrected for common $\mathrm{Pb}$ and anchored at a common $\mathrm{Pb}$ composition, define a lower intercept age in the Tera Wasserburg diagram at $1158 \pm 12$ Ma (Fig. 13e, SIMS data, $n$ $=8, \mathrm{MSWD}=0.24, \mathrm{Th} / \mathrm{U}=0.43)$. This age is interpreted to record the crystallization of the zircon phenocrysts before extrusion of the rhyolite. It implies that the rhyolite correlates with the $1155 \pm 2$ Ma Brunkeberg porphyry. Therefore, the age relations sup port the interpretation proposed by Lamminen (2011), that the Lifjell quartzite was limited by a normal fault, active when accumulation of the Garborg quartzite and Brunkeberg rhyolite took place around 

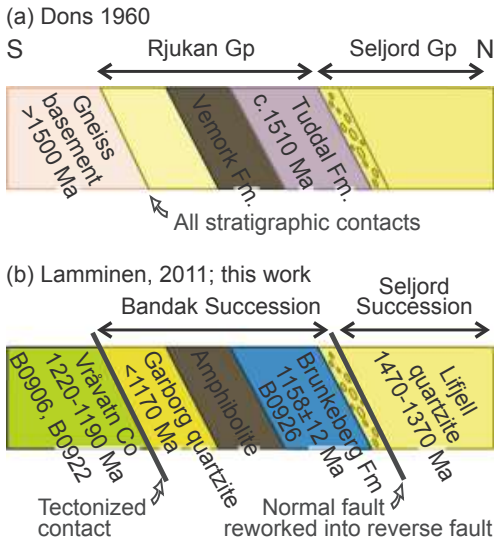

Fig. 14. Conceptual c. $5 \mathrm{~km}$ long N-S cross section through the contact between the Telemark supracrustal rocks and the Vråvatn Complex in the Seljordvatnet area (Fig. 3), showing the evolution of interpretations. Same color coding as in Fig. 3. (a) Stratigraphic contacts following Dons (1960a; 1960b) and Dons and Jorde (1978). (b) Seljord Succession bounded against the $1158 \pm 12 \mathrm{Ma}$ Brunkeberg Formation by a normal fault (c. 1170-1150 Ma) reworked into a reverse fault (c. $1000 \mathrm{Ma}$ ), following Lamminen (2011) and this work.

$1158 \mathrm{Ma}$ and that this contact was subsequently inverted into a reverse shear zone after c. $1158 \mathrm{Ma}$, placing the Seljord Succession above the younger Bandak Succession.

\subsubsection{B0902, augen gneiss}

Sample B0902 is representative of the monotonous granitic gneiss in the Telemarkia footwall of the Kristiansand Porsgrunn Shear Zone north of Kragerø (Fig. 7). The outcrop contains a flat lying amphibolite facies foliation and a weak compositional layering. The sample is a biotite amphibole augen gneiss. Prismatic zircon with typical oscilla tory growth zoning yields an age of $1146 \pm 7 \mathrm{Ma}$ for intrusion of the protolith to this gneiss (Fig. 13f, SIMS data, ${ }^{207} \mathrm{~Pb} /{ }^{206} \mathrm{~Pb}$ age, $\mathrm{n}=11$, MSWD $=0.90, \mathrm{Th} / \mathrm{U}=0.37$.

\subsubsection{B1212, granite}

Sample B1212 was collected near Åmli also in the Telemark foot wall of the Kristiansand Porsgrunn Shear Zone in an extensive unit mapped as migmatitic gneiss (Fig. 7) (Padget and Brekke, 1996). The locality consists of coarse (5 $10 \mathrm{~mm})$, leucocratic, biotite granite, con taining a weak but undisputable foliation (NW dipping) and a weak compositional layering at decimetric to metric scale parallel to the fo liation. The sample is layered with layers variably enriched in biotite. Zircon is rare, prismatic, partly fractured and characterized by a weak CL signal. Six analyses could be performed in zircon with a weak os cillatory to prismatic zoning and high $\mathrm{U}$ content (U $>800 \mathrm{ppm})$. Analyses, uncorrected for common $\mathrm{Pb}$ and anchored at a common $\mathrm{Pb}$ composition, define a lower intercept age in the Tera Wasserburg dia gram at $969 \pm$ 13 Ma with some scatter (Fig. 13g, SIMS data, $\mathrm{n}=6$, MSWD $=2.9$, over dispersion of data, $\mathrm{Th} / \mathrm{U}=0.15)$. This age is in terpreted to record the magmatic crystallization of this differentiated granite. It dismisses a correlation between the sampled locality and the $1205 \pm 8$ Ma Drivheia granitic gneiss exposed c. $20 \mathrm{~km}$ to the east and described in Heaman and Smalley (1994). It suggests that the dated outcrop is part of the large late Sveconorwegian Tørdal Treungen pluton, extensively exposed north of Åmli.

\subsection{Idefjorden Unit, Gothian Telemarkian orthogneisses and paragneisses}

In the Idefjorden Lithotectonic Unit, west of the Oslo Rift, the Veme Complex (Fig. 3) consists of a thick package of psammite and grey wacke, metamorphosed under amphibolite facies conditions (Bingen et al., 2001b). Locally, the metasediments are deformed by open to close folds, axial planar cleavage and preserved syn deposition graded bedding (Bouma sequence with rare slump structures), implying tur bidite sedimentation. Elsewhere, metasediments are gneissified and transformed into biotite muscovite mica gneiss, variably migmatitic and intruded by pegmatite bodies. The paragneisses are associated with orthogneisses, representing both mafic or felsic plutonic rocks. One of those, the Follum diorite tonalite is dated at $1555 \pm 3 \mathrm{Ma}$ (Bingen et al., 2005), and therefore attributed to the plutonic Hisingen Suite, extensively exposed in the Idefjorden Unit east of the Oslo Rift. The relative chronology between the plutonic rocks and the metasedimen tary rocks can not be solved in the field, as both are affected by Sve conorwegian metamorphism around 1050 Ma (Bingen et al., 2008b). New data on four orthogneisses and one paragneiss are presented hereafter.

\subsubsection{BBI121, garnet bearing quartz dioritic gneiss, Veme Complex}

Sample BBI121 is from an outcrop of weakly layered, garnet bearing, quartz dioritic gneiss, containing a few, c. $50 \mathrm{~cm}$ thick isoclinally folded quartzofeldspathic layers (Fig. 5). The outcrop is part of a c. $1 \mathrm{~km}$ thick package of heterogeneous gneiss exposing alternating greywacke arkose metasediment and dioritic to quartz dioritic orthogneiss. Both are highly deformed and the foliation trends inconsistently from NW to SE. In sample BBI121, rounded to prismatic zircon crystals with oscillatory to sector zoning yield an age of $1550 \pm 7 \mathrm{Ma}$ (Fig. 13h, SIMS data, ${ }^{207} \mathrm{~Pb} /{ }^{206} \mathrm{~Pb}$ age, $\mathrm{n}=9, \mathrm{MSWD}=0.86$, Th/ $\mathrm{U}=0.66$ ), recording plutonic crystallization.

\subsubsection{B0825, granodioritic gneiss, Snaukollen granodiorite, Veme Complex}

A foliated granodiorite, informally called the Snaukollen grano diorite, occupies part of the axial surface of the Norefjell Hønefoss fold described by Scheiber et al. (2015) (Fig. 5). This lithodeme ranges from poorly foliated to foliated towards the margin. Sample B0825 is a fo liated biotite bearing granodiorite. Prismatic oscillatory zoned zircon yields an age of $1540 \pm 6 \mathrm{Ma}$ (Fig. 13i, SIMS data, ${ }^{207} \mathrm{~Pb} /{ }^{206} \mathrm{~Pb}$ age, $\mathrm{n}=8, \mathrm{MSWD}=1.12, \mathrm{Th} / \mathrm{U}=0.44$ ), recording crystallization of the pluton. In a nearby locality, $2.5 \mathrm{~km}$ away and $500 \mathrm{~m}$ across strike, metagreywacke metasandstone with spectacularly preserved graded bedding contains detrital zircon in the range $1673 \pm 16$ to $1533 \pm 16 \mathrm{Ma}$ (sample N95128 in Bingen et al., 2001b). The overlap between the age of the youngest detrital zircon grains of this sample $(1537 \pm 44$ and $1533 \pm 16 \mathrm{Ma})$ and the age of $1540 \pm 6 \mathrm{Ma}$ of the granodiorite suggests that, in this area, the metasediments of the Veme Complex are younger and therefore probably overlie the orthogneiss.

\subsubsection{BBI220, two pyroxene diorite gneiss, Veme Complex}

In the area of Tyristrand (Fig. 3), a c. $1.5 \mathrm{~km}$ wide unit of penetratively foliated, consistently mafic (dioritic) gneiss is characterized by a two pyroxene and magnetite granulite facies assemblage. Sample BBI220 of this gneiss (Fig. 5) contains large rounded sector, fir tree, zoned, zircon crystals. A few crystals are rich in U (440 600 ppm) while most are poor in U (50 $90 \mathrm{ppm})$. Twelve analyses in U rich and $U$ poor zircon are well clustered and concordant. They give an age of $1540 \pm 8$ Ma (Fig. 13j, SIMS data, ${ }^{207} \mathrm{~Pb} /{ }^{206} \mathrm{~Pb}$ age, $\mathrm{n}=12$, MSWD $=0.53$, Th/U $=0.34)$. Fir tree sector zoned zircon can form in both magmatic and metamorphic environment (Vavra et al., 1999). It is probable that the granulite facies two pyroxene assemblage formed during the magmatic crystallization of the protolith at $1540 \pm 8 \mathrm{Ma}$.

\subsubsection{BBI213, garnet bearing granitic gneiss, Veme Complex}

Sample BBI213 is from a $50 \mathrm{~m}$ thick granitic gneiss layer in an heterogeneous package of banded and migmatitic paragneisses (Fig. 5). This package includes variably migmatitic garnet biotite and mafic gneiss levels. The sample is characterized by phenoclasts of garnet and a pronounced planar fabric defined by quartz ribbons and biotite stripes. The sample contains small rounded to prismatic zircon crystals, characterized by a core rim texture. The core is oscillatory zoned and 


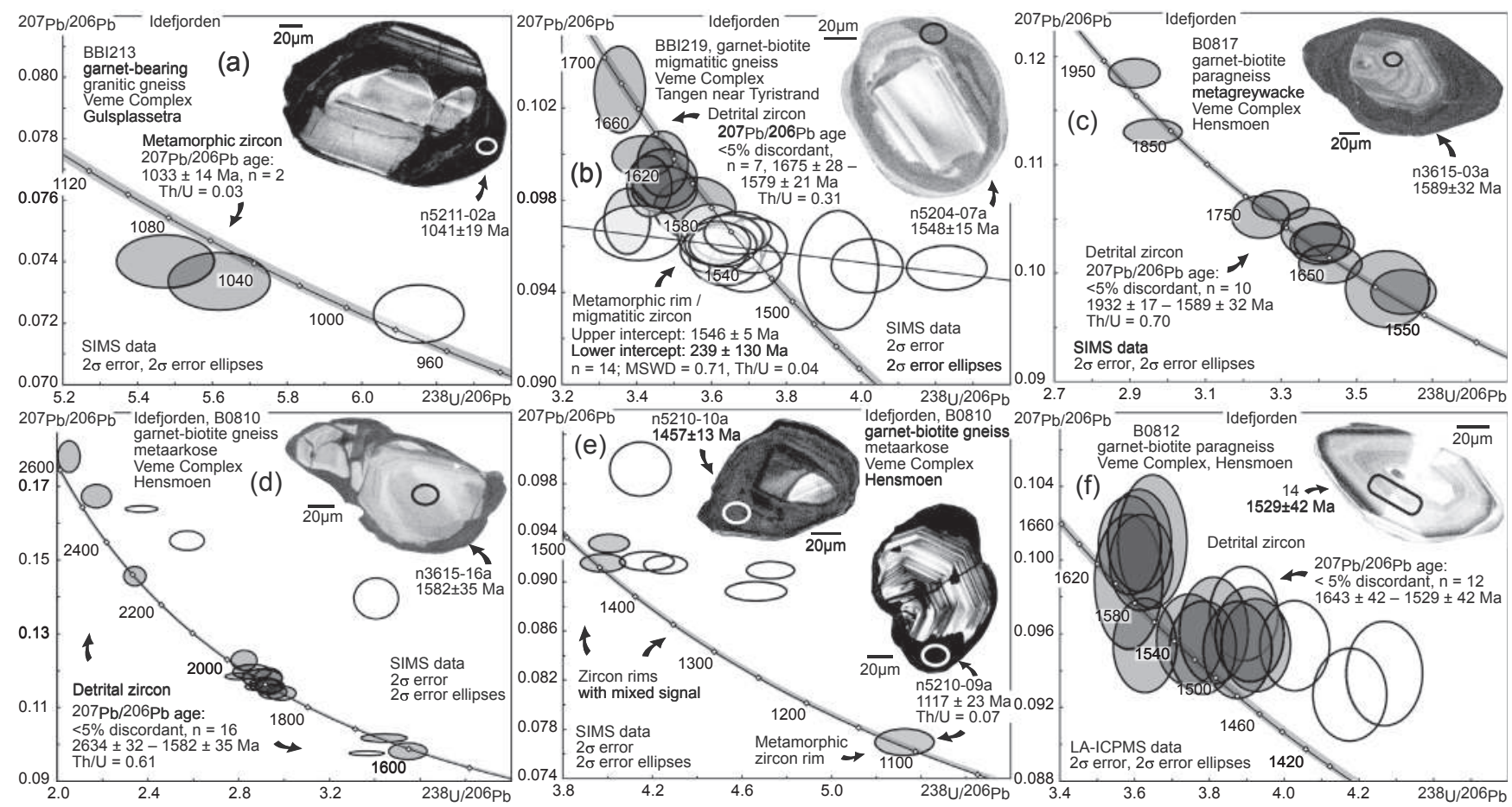

Fig. 15. Zircon U-Pb data and selected CL images.

yields an age of $1492 \pm 8 \mathrm{Ma}$ (Fig. 131, SIMS data, ${ }^{207} \mathrm{~Pb} /{ }^{206} \mathrm{~Pb}$ age, $\mathrm{n}=8, \mathrm{MSWD}=0.82, \mathrm{Th} / \mathrm{U}=0.40$ ). This age records intrusion of the orthogneiss protolith. The rim is generally thin, has low CL signal (CL dark), is rich in $U(620<U<750 \mathrm{ppm})$ and is poor in Th (Th/ $\mathrm{U}=0.03$ ). Two analyses could be safely placed in non metamict and non fractured rim material, giving an age of $1033 \pm 14$ Ma (Fig. $15 \mathrm{a}, \mathrm{n}=2$, Th/ $\mathrm{U}=0.03$ ). This age is indicative of the timing of amphibolite facies metamorphism at this locality.

\subsubsection{BBI219, garnet biotite migmatitic paragneiss, Veme Complex}

At several localities near Tyristrand (Fig. 3) feldspar appears as dark green, characteristic of granulite facies assemblages. Sample BBI219 (Fig. 5) represents an exposure of fine grained, garnet bearing, migmatitic gneiss with dark feldspar. Mesosome layers are rich in biotite with bronze color. In the leucosomes, garnet phenoblasts reach $1 \mathrm{~cm}$ in diametre. The exposure is interpreted as a paragneiss package interlayered inside a dominant orthogneiss package of quartz dioritic to dioritic composition (as represented by sample BBI220 collected c. $1.5 \mathrm{~km}$ across strike northeast of BBI219). Sample BBI219 contains thin layers of both leucosome and melanosome, both containing garnet and biotite. No orthopyroxene is observed, and therefore we cannot confirm that metamorphism reached granulite facies in the sample. The zircon shows a core rim texture with a variably thick rim. The core is generally oscillatory to sector zoned, while the rim is concentrically zoned. A CL bright seam is commonly located at the interface between core and rim. Both the core and rim are comparatively rich in $\mathrm{U}$ $(100<\mathrm{U}<600 \mathrm{ppm})$; however, the rim is much lower in Th than the core $(\mathrm{Th} / \mathrm{U}=0.04$ for the rim vs. 0.31 for the core). Seven $\mathrm{U} \mathrm{Pb}$ analyses of the core are near concordant and range in age from $1675 \pm 26$ to $1579 \pm 21 \mathrm{Ma}$ (Fig. 15b, SIMS analyses, < 5\% discordance, ${ }^{207} \mathrm{~Pb} /{ }^{206} \mathrm{~Pb}$ age). Fourteen analyses of the rim define a discordia line with an upper intercept age of $1546 \pm 5$ Ma and a lower intercept age of $239 \pm 130 \mathrm{Ma}$ (Fig. 15b, MSWD = 0.71). The cores are interpreted as detrital, while the low $\mathrm{Th} / \mathrm{U}$ rims as metamorphic in origin. This result suggests that the metasedimentary protolith of the paragneiss was deposited between $1579 \pm 21$ (youngest detrital core) and $1546 \pm 5 \mathrm{Ma}$ (metamorphic rim). The age of $1546 \pm 5 \mathrm{Ma}$ for the rim implies that amphibolite to granulite facies metamorphism in this paragneiss is coeval with intrusion of the protolith of the nearby dioritic gneiss at $1540 \pm 8 \mathrm{Ma}$ (sample BBI220) probably directly in granulite facies conditions. The age of $1546 \pm 5 \mathrm{Ma}$ is the first robust evidence for Gothian high grade metamorphism west of the Oslo Rift.

\subsection{Idefjorden Unit, Veme Complex, Hensmoen locality}

The c. $3 \mathrm{~km}$ long road section in Hensmoen (road E16) exposes NW SE trending, SW dipping foliated gneisses of the Veme Complex (Figs. 3 and 5). The section consists of packages of layered gneiss variably rich in biotite and variably migmatitic, interpreted as paragneiss, and packages of more homogeneous gneiss containing amphibole and biotite, interpreted as orthogneiss. Garnet blastesis is ubiquitous, while muscovite is generally absent. Garnet growth predates the last deformation phase imparting the main SW dipping foliation observed in the section. One granodioritic orthogneiss gave a protolith age of $1496 \pm 9 \mathrm{Ma}$ (Petersson et al., 2015b) and a few zircon rims in the same sample provided an indication of $1069 \pm 11$ Ma for metamorphism.

The Hensmoen road section is important because it contains a kyanite garnet rutile bearing paragneiss, giving rare evidence for high pressure granulite facies metamorphism $\left(780{ }^{\circ} \mathrm{C} 1.17 \mathrm{GPa}\right.$; sample B99137 in Bingen et al., 2008b; their Fig. 6). The kyanite garnet rutile gneiss hosts several mafic boudins ( $50 \mathrm{~cm}$ to $10 \mathrm{~m}$ in size) with a clinopyroxene garnet rutile assemblage also characteristic of high pressure granulite facies. This assemblage yields an estimate of $930{ }^{\circ} \mathrm{C} 1.3 \mathrm{GPa}$, substantiating the high pressure signature of metamorphism at this locality (Bingen et al., 2014). Monazite in the kyanite garnet rutile gneiss gave a robust age of $1052 \pm 4 \mathrm{Ma}$ for the high pressure metamorphism (Bingen et al., 2008b). Amber oblate shaped titanite range in age from $1043 \pm 8$ to $1024 \pm 9 \mathrm{Ma}$ in two samples along the road section and records exhumation of this rock package shortly after peak metamorphism.

\subsubsection{B99140, garnet amphibole bearing augen gneiss, Veme Complex}

Sample B99140 represents a $3 \mathrm{~km}$ long mappable unit exposed 
mainly northeast of the road section and just north of the kyanite garnet rutile gneiss (Fig. 5). It is made of granodioritic augen gneiss, characterized by $\mathrm{K}$ feldspar augen in a gneiss matrix containing garnet, amphibole, biotite and titanite. Zircon is rounded to prismatic, with concentric to oscillatory zoning. Sixteen LA ICPMS analyses in zircon cluster and give an age estimate of $1499 \pm 10 \mathrm{Ma}$ (Fig. $13 \mathrm{k}, 207 \mathrm{~Pb} /{ }^{206} \mathrm{~Pb}$ age, MSWD $=0.34$ ), dating the intrusion of the magmatic protolith. This age is equivalent to the age of $1496 \pm 9 \mathrm{Ma}$ of a gran odioritic orthogneiss, lacking an augen texture, collected c. $1 \mathrm{~km}$ northwest of B99140 (Petersson et al., 2015b).

3.8.2. B0817, layered garnet biotite gneiss, metagreywacke, Veme Complex Sample B0817 was collected from a layered gneiss with an average felsic composition (Fig. 5). The sample contains biotite and large garnet phenoblasts, and is interpreted as a metagreyawacke metapsammite. Detrital zircon grains are rounded and oscillatory zoned, locally with a thin metamorphic rim. The ${ }^{207} \mathrm{~Pb} /{ }^{206} \mathrm{~Pb}$ age of 10 of them range from $1932 \pm 17$ to $1589 \pm 32 \mathrm{Ma}$, with a frequency maximum around $1680 \mathrm{Ma}$ (Fig. 15c, SIMS analyses).

\subsubsection{B0810, garnet biotite gneiss, metaarkose, Veme Complex}

Sample B0810 is from the outcrop of the kyanite garnet rutile bearing paragneiss described in Bingen et al. (2008b) (their sample B99137; Fig. 5). It is a quartz rich layered and migmatitic gneiss, containing garnet and biotite, interpreted as a metaarkose. Zircon crystals are rounded and characterized by a core rim texture. The core is variably oscillatory to sector zoned and interpreted as detritic. Six teen of the $20 \mathrm{U} \mathrm{Pb}$ analyses performed in cores are near concordant and range in age from $2634 \pm 32$ to $1582 \pm 35$ Ma (Fig. 15d, SIMS data, $<5 \%$ discordance, ${ }^{207} \mathrm{~Pb} /{ }^{206} \mathrm{~Pb}$ age, $\mathrm{n}=16, \mathrm{Th} / \mathrm{U}=$ 0.61 ). A pronounced frequency maximum at $1890 \mathrm{Ma}$ points to a Svecofennian aged provenance area for this sediment. The rim has low CL signal (CL dark), is rich in U (600 $1400 \mathrm{ppm}$ ) and poor in Th (Th/U $=0.01$ ). The rim shows inwards directed embayements, and is clearly replacing the core. Uranium lead analyses of the rim scatter between $1490 \pm 12$ and $1118 \pm 23$ Ma (Fig. 15e). The rim analyses can not be interpreted re liably.

\subsubsection{B0812, garnet biotite gneiss, metagreywacke, Veme Complex}

Sample B0812 is from a rather homogeneous package of fine grained biotite garnet gneiss, interpreted as metagreywacke me tapsammite (Fig. 5). Detrital zircon grains are rounded to prismatic and generally oscillatory zoned. They do not contain metamorphic rims. Twelve LA ICPMS U Pb analyses range from $1643 \pm 42$ to $1529 \pm 42 \mathrm{Ma}$ (Fig. 15f, $<5 \%$ discordance) with an age frequency maximum at c. $1540 \mathrm{Ma}$.

\section{Geological evolution of the Kongsberg Lithotectonic Unit}

\subsection{Gothian Telemarkian evolution}

New $\mathrm{U} \mathrm{Pb}$ zircon data collected from sixteen orthogneiss samples (Table 1) of the Kongsberg Complex, together with published data from three samples (Andersen et al., 2004a), define the magmatic crystal lization age of the orthogneisses between $1567 \pm 6$ and $1485 \pm 12 \mathrm{Ma}$, with a frequency maximum at c. $1505 \mathrm{Ma}$ (Fig. 2). The ages do not belong to an obvious systematic geographical trend inside the Kongsberg Unit, except that the oldest records are in the north, not far from the contact with the Idefjorden Unit. The dataset demonstrates a near total overlap inside the Kongsberg Complex between magmatic rocks typically assigned to the Gothian accretionary event (1660 1520 $\mathrm{Ma}$, characteristic of the Idefjorden Unit), and rocks as signed to the Telemarkian accretionary event (1520 $1480 \mathrm{Ma}$, char acteristic of the Telemarkia Unit). The abundance of 15201480 Ma magmatism in Kongsberg is notable and clearly links the Kongsberg Unit with the Telemarkia Unit before the Sveconorwegian orogeny.
Deposition of the sediment sequence in the Modum Complex took place after $1467 \pm 33 \mathrm{Ma}$, as estimated by detrital zircon $\mathrm{U} \mathrm{Pb}$ data in a quartzite sample (Fig. 4) (Bingen et al., 2001b). A minimum age of 1434 $\pm 29 \mathrm{Ma}$ was proposed by Andersen and Grorud (1998), based on a Pb $\mathrm{Pb}$ errorchron in a cobalt mineralized sulfide and uraninite rich layer in the metasedimentary complex (Skuterud historic mines). Available data therefore indicate that the Modum Complex probably represents a cover succession above orthogneisses of the Kongsberg Complex. New detrital zircon $\mathrm{U} \mathrm{Pb}$ data from an orthoamphibole cor dierite gneiss sample from the Modum Complex support a metasedi mentary protolith for this metasomatic rock (BBI122, detrital zircon cores ranging from $2641 \pm$ 10 to $1746 \pm 20$ Ma, Fig. 10e, Table 1), as suggested by Munz (1990). However, the data do not help to con solidate the maximum deposition age of the sediment sequence in the Modum Complex (Fig. 4).

A number of metagabbro bodies, occur within both the Kongsberg and Modum Complexes. They are mechanically more competent than the host gneisses, as the regional gneissic fabric is deflected around them (Fig. 5) (Viola et al., 2016). In their less deformed cores, a mag matic (sub)ophitic olivine bearing texture is commonly preserved (Munz and Morvik, 1991). Elsewhere, gabbro is transformed to garnet amphibolite. Metagabbro generally lacks zircon and is therefore diffi cult to date with $\mathrm{U} \mathrm{Pb}$ geochronology. A sample of a coronitic meta gabbro in the Modum Complex, containing a partially preserved mag matic mineral assemblage, yielded a Sm Nd mineral isochron age of $1224 \pm 15 \mathrm{Ma}$ (initial $\varepsilon_{\mathrm{Nd}}=+1.4$ ), arguably dating the crystallization of the magmatic assemblage (Morud metagabbro; Munz and Morvik, 1991). The Holleia metagabbro body (Fig. 5) is characterized by an internal ENE trending layering, pre dating the regional NNW SSE gneissic fabric of the hosting Kongsberg Complex. An ENE trending layer of granitic gneiss in the metagabbro yields an intrusion age of $1507 \pm 6$ Ma (BBI106, Fig. 8k, Table 1), tentatively interpreted as a minimum intrusion age for the host gabbro. The garnet bearing Vinoren metagabbro (Fig. 5) (Jacobsen and Heier, 1978) hosts fine grained granitic dykes and sills, dated at $1151 \pm$ $8 \mathrm{Ma}$ (BBI10, Fig. 10a) and $1164 \pm 12$ Ma (BBI01, Fig. 9j). These provide a distinctly younger minimum age for the intrusion of their host. Available data therefore point to several generations of mafic plutonism in the Kongsberg Unit.

\subsection{Sveconorwegian evolution}

Fine grained, granitic to granodioritic orthogneiss sheets crop out in the western part of the Kongsberg Complex (Table 1). Two such sheets, $<500 \mathrm{~m}$ thick, yield ages of $1167 \pm 12 \mathrm{Ma}$ (BBI04, Fig. 9i) and $1157 \pm 10 \mathrm{Ma}$ (BBI05, Fig. 91). This rock type is foliated and contains an amphibolite facies metamorphic assemblage similar to those of the $15701485 \mathrm{Ma}$ orthogneissic host rock. Its volumetric importance is probably only minor inside the Kongsberg Unit. Its mere presence, however, sets an important maximum age for the main deformation and metamorphism.

Metamorphism in the Kongsberg Unit increases from epidote am phibolite facies in the southwest to upper amphibolite facies conditions in the Modum Complex and eastward. There, orthogneisses contain a typical hornblende, titanite and garnet assemblage and migmatitization is widespread in rocks of appropriate composition. In the eastern part of the Kongsberg Complex, moreover, granulite facies rocks are locally preserved. At a few localities, relatively poorly foliated mafic rocks are characterized by a garnet clinopyroxene plagioclase assemblage, at testing to high pressure granulite facies conditions.

Published geochronological data constraining the timing of high grade metamorphism in the Kongsberg Unit are not abundant (Fig. 5). In the Modum Complex, they include a single SIMS analysis of a zircon rim at $1102 \pm 28 \mathrm{Ma}$ in a quartzite (Bingen et al., 2001b), a $\mathrm{Pb} \mathrm{Pb}$ errorchron age and a molybdenite Re Os model age of $1146 \pm 66 \mathrm{Ma}$ and $1112 \pm 4 \mathrm{Ma}$, respectively, in mineralized sulfide rich schists from the Skuterud historic cobalt mine (Andersen and Grorud, 1998; Bingen 
et al., 2008b), a monazite $\mathrm{U} \mathrm{Pb}$ age of $1092 \pm 1 \mathrm{Ma}$ in a sillimanite gneiss (Bingen et al., 2008b), and a titanite age of $1080 \pm 3$ Ma recording metasomatism in albitite (Munz et al., 1994). New U Pb data on metamorphic zircon were collected in three samples in our study (Table 1). Metamorphic zircon rims are rich in $U$ and poor in Th and correspond to both overgrowth and inwards directed recrystallization of zircon. These rims probably formed in melt present conditions (Harley et al., 2007; Laurent et al., 2018; Rubatto et al., 2001; Vavra et al., 1999). Two of the samples are from the Kongsberg Complex just east of the contact with the Modum Complex, and belong to a steeply dipping, high strain, garnet bearing banded gneiss. Some of the felsic layers probably correspond to deformed leucosome. Zircon rims from a granodioritic layer (BBI125, Fig. 10g) and a quartz dioritic layer (BBI107, Fig. 8b) yield ages of $1138 \pm 8 \mathrm{Ma}$ and $1132 \pm 11 \mathrm{Ma}$ re spectively. The third sample is a migmatitic garnet bearing mica gneiss from the Modum Complex. Zircon rims give an age of $1123 \pm 9$ Ma (BBI100; Fig. 10d). The three dates overlap within error, although the one at $1123 \pm 9 \mathrm{Ma}$ is nominally younger and could record a distinct post peak crystallization of partial melt observed at this locality (Yakymchuk and Brown, 2014). The new age determinations (1138 \pm 8 to $1123 \pm 9 \mathrm{Ma})$ are significantly older and more robust than the published ones (mainly from $1112 \pm 4$ to $1092 \pm 1 \mathrm{Ma}$ ) and provide a better estimate of peak (or near peak) regional amphibolite facies metamorphism associated with partial melting in the Kongsberg Unit.

The Sveconorwegian amphibolite facies ductile fabric in both the orthogneiss and metasedimentary complexes is on average very steep to subvertical (Fig. 16a) and tightly to isoclinally folded along variably plunging N S fold axes, at all scales (Fig. 16c and several examples in Fig. 6) (Scheiber et al., 2015). This fabric is interpreted as the product of overall $\mathrm{E} \mathrm{W}$ shortening. The stretching lineations collected over the entire Kongsberg Unit exhibit a variable attitude along a generally $\mathrm{N} \mathrm{S}$ trending girdle (Fig. 16b). The dataset is heterogeneous, though, and contains many readings of relatively shallow plunging lineations asso ciated with late to post Sveconorwegian strike to oblique slip shear zones that bound and dissect internally the lithotectonic unit. A steep high strain zone, for example, is located in the Kongsberg Complex along the western contact of the Modum Complex (Hokksund So lumsmo mylonite zone of Starmer, 1985). This zone exhibits evidence of sinistral strike slip shearing (Fig. 5) and associated drag folds with steep axis superposed on E W shortening related structural features. Considering only the area around lake Væleren in the eastern part of the Kongsberg Complex (Fig. 5), a steeply dipping and highly transposed mylonitic to ultramylonitic fabric (Fig. 17) contains a steep stretching lineation (Fig. 17b) and is isoclinally folded around steep to subvertical fold axes (Fig. 17c and e). Field examples and geometric data shown in Fig. 17 are representative of the overall strain conditions within the Kongsberg Unit.

\subsection{Post deformation lamprophyre dyke}

A lamprophyre (vogesite) dyke in the eastern part of the Kongsberg Complex is characterized by an unfoliated chilled margin with subophitic texture, and sharply crosscuts the mylonitic foliation in the Væleren area (Fig. 11f h). The zircon $\mathrm{U} \mathrm{Pb}$ intrusion age of $1033 \pm 12$ Ma for the dyke (BBI138; Fig. 10b, Table 1) is a key re gional time marker. It requires that amphibolite facies deformation (locally up to granulite facies conditions) that led to the regional scale steep $\mathrm{N} \mathrm{S}$ trending fabric and even the following exhumation to upper crustal level was accommodated before intrusion of the dyke (with chilled margin) at c. $1033 \mathrm{Ma}$. It also constrains ultrapotassic mafic magmatism after the peak of regional metamorphism.

\subsection{Kongsberg Telemark boundary}

The Kongsberg Telemark boundary (Fig. 3) is described in detail by
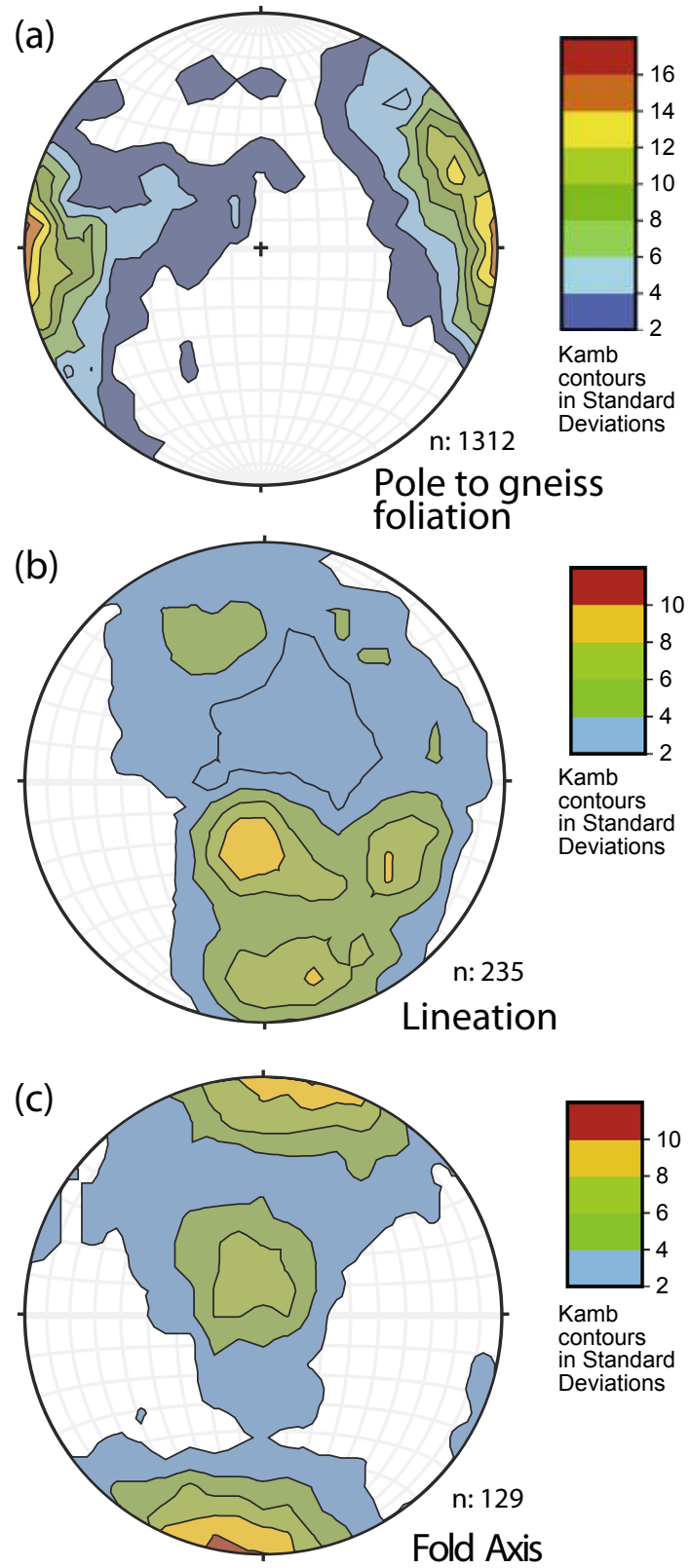

Fig. 16. Lower hemisphere stereographic projection of structural elements of the Kongsberg Unit.

Scheiber et al. (2015). It includes structures that can be ascribed to several ductile and brittle events. The main Sveconorwegian ductile shear zone, the Saggrenda Sokna Shear Zone, is an east dipping multiply reactivated shear zone, largely hosted within and along the eastern margin of a more than $100 \mathrm{~km}$ long belt of foliated granite and granitic gneiss. The granite belt was emplaced between $1174 \pm 11$ and $1146 \pm 5 \mathrm{Ma}$ (Bingen et al., 2005; Scheiber et al., 2015) (and this work, B0945, Fig. 13d, Table 1), thus providing a maximum age con straint for the relative movement between the two tectonically juxtaposed Lithotectonic Units.

Following Scheiber et al. (2015), the Sveconorwegian tectonic evolution along the Kongsberg Telemark boundary can be summarized by three ductile deformation phases. The earliest is recorded by top to the west structures, which constrain thrusting of the Kongsberg Unit over the Telemarkia Unit. A phase of sinistral ductile shearing forming mylonitic to ultramylonitic gneisses, selectively reactivated the thrust related structures, and was followed by late Sveconorwegian extensional top to the east shearing. The last extensional episode 

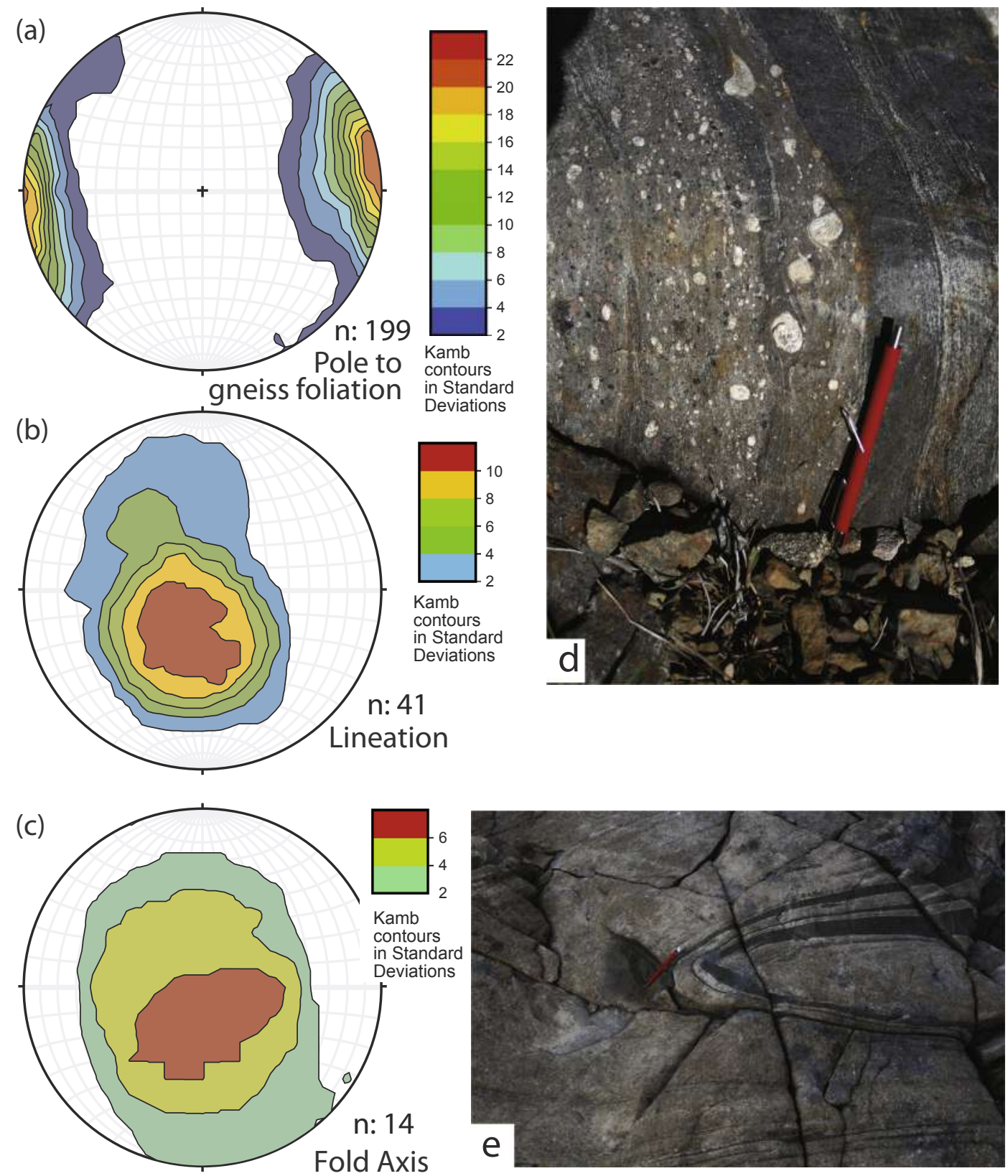

Fig. 17. Lower hemisphere stereographic projection of structural elements and field relationships in the Væleren area (Fig. 3). (d) Steeply dipping mylonitic gneiss with phenoclasts of feldspar; (e) Mylonitic granitic gneiss, similar to sample BBI134 (1541 \pm 4 Ma, Fig. 8f) with steeply plunging isoclinal fold whose axis is parallel to red pencil.

accommodated the extensional exhumation of the Telemarkia Unit in the footwall.

\subsection{Kongsberg Idefjorden boundary}

The Kongsberg Idefjorden boundary depicted by the new geological map of Viola et al. (2016) follows the updated lithological contact between the Kongsberg Complex dominated by orthogneiss and the Veme Complex dominated by muscovite biotite bearing paragneiss typical of the Idefjorden Unit (Figs. 3 and 5). The contact is marked by a c. $500 \mathrm{~m}$ thick amphibolite facies shear zone, west of Tyristrand, made of banded gneiss of mafic composition on the Kongsberg Complex side of the boundary. It is characterized by steeply dipping foliation planes and moderate to steeply plunging lineations.

\section{Geological evolution of the Bamble Lithotectonic Unit}

\subsection{Gothian Telemarkian evolution}

The geochronology of orthogneisses in the Bamble Unit is constrained by eight published $\mathrm{U} \mathrm{Pb}$ age determinations. These range from $1572 \pm 20$ to $1460 \pm 21 \mathrm{Ma}$, with a frequency peak at c. $1545 \mathrm{Ma}$ (Fig. 2) (Andersen et al., 2004a; deHaas et al., 2002a; Engvik et al., 2016; Kullerud and Machado, 1991). The magmatic protolith of the granulite facies enderbite Tromøy Complex (Figs. 3 and 7) consists of low K calcalkaline noritic to tonalitic rocks. The age of oscillatory zoned zircon cores in five samples ranges from $1575 \pm 44 \mathrm{Ma}$ (B1204, Fig. 10i) to $1544 \pm 14$ Ma (B0855; Fig. 12d), overlapping within error. Therefore, the Tromøy Complex can be interpreted as a single mag matic complex of Gothian age. The timing of deposition of quartzite an other sediments in the Nidelva and Kragerø Complexes (Nijland et al., 
2014; Nijland et al., 1993), is poorly constrained, as only a couple of detrital zircons provide a maximum deposition age of $1491 \pm 20 \mathrm{Ma}$ (Åhäll et al., 1998). However, by analogy to the Modum Complex, it is probable that the sediments represent a cover sequence above the or thogneiss basement.

\subsection{Sveconorwegian evolution}

The 15751460 Ma ortho and paragneiss complexes were intruded by younger plutonic rocks (Fig. 2). A coronitic metagabbro in Vestre Dale yielded a Sm Nd mineral isochron age of $1207 \pm 14 \mathrm{Ma}$ (deHaas et al., 2002b). Prominent zoned charnockite augen gneiss units, at least 1 $\mathrm{km}$ wide in map view, are characterized by a weakly foliated orthopyroxene bearing charnockitic facies, more common in the centre of the unit, and a well foliated biotite \pm amphibole \pm garnet bearing augen gneiss facies more common towards the margin (Touret, 1971a,b). The charnockite is interpreted to be a relic magmatic facies, while the augen gneiss is reworked parallel to the NE SW trending regional amphibolites facies fabric. New $\mathrm{U} \mathrm{Pb}$ data from prismatic oscillatory zoned zircon yield estimates for magmatic crystallization of $1152 \pm 11 \mathrm{Ma}$ (B1206, Fig. 12h), $1150 \pm 13 \mathrm{Ma}$ (B1207, Fig. 12i) and $1140 \pm 13 \mathrm{Ma}$ (B1208, Fig. 12j) for the Gjeving, Ubergsmoen and Hovdefjell Vegår shei charnockite augen gneiss lithodemic units respectively (Fig. 7; Table 1). These dates represent maximum age brackets for the gneissic fabric and amphibolite facies garnet bearing metamorphic assemblage. The 11801140 Ma magmatism (Fig. 2) also includes thin conformable sheets of metagabbro and felsic orthogneiss, which are, however, difficult to distinguish from their older host gneisses (Andersen et al., 2004b; Engvik et al., 2016, 2011).

Metamorphism in Bamble is associated with intense deformation, fabric transposition and development of lithological banding. The regional metamorphic grade increases southeastwards, towards the is lands of Tromøy and Hisøy, that is, perpendicularly to the regional structural grain (Fig. 7). Four main isograds can be mapped. In order of increasing metamorphic grade, these are muscovite out in metapelitic rocks, orthopyroxene in in mafic rocks, cordierite in in metapelitic rocks and orthopyroxene in in felsic rocks (Fig. 7) (Clough and Field, 1980; Nijland et al., 2014; Nijland and Maijer, 1993; Touret, 1971a). Patches of granulite facies rocks, however, are scattered throughout the amphibolite facies domain, implying that the concept of a smooth in crease in metamorphic temperature towards the centre of the domain is invalid (Engvik et al., 2016; Nijland et al., 1998). Thermobarometric estimates in the granulite facies domain yield consistent values of $\mathrm{P}=$ $0.60 .8 \mathrm{GPa}$ and $\mathrm{T}=750850{ }^{\circ} \mathrm{C}$ in the stability field of sillimanite (Harlov, 2000; Knudsen, 1996; Lamb et al., 1986; Nijland and Maijer, 1993). Localities of granulite facies rocks in the amphibolite facies domain yield equivalent to higher estimates up to $\mathrm{P}=1.15 \mathrm{GPa}$ and $\mathrm{T}$ $=850{ }^{\circ} \mathrm{C}$ (Engvik et al., 2016). No concensus exists yet on a clockwise versus anticlockwise pressure temperature path for the high grade metamorphism in Bamble (Nijland et al., 2014).

The age of metamorphism in Bamble is constrained by abundant $\mathrm{U} \mathrm{Pb}$ and ${ }^{40} \mathrm{Ar} /{ }^{39} \mathrm{Ar}$ data. Analyses of metamorphic zircon rims in the amphibolite and granulite facies domains cluster between $1139 \pm 11$ and $1122 \pm 8$ Ma (Engvik et al., 2016; Knudsen et al., 1997). In the granulite facies domains, monazite from three localities of metapelitic gneiss gives ages between $1145 \pm 3$ and $1135 \pm 6 \mathrm{Ma}$ (Bingen et al., 2008b; Cosca et al., 1998). In the rest of the amphibolite facies domain, monazite from two samples of impure quartzite in the Nidelva and Kragerø Complexes yielded age clusters at $1134 \pm$ $14,1127 \pm 6$ and $1107 \pm 9$ Ma (Bingen et al., 2008b).

In the Tromøy Complex, zircon rims and small metamorphic zircon crystals in six samples (Fig. 10; Fig. 12), range from $1147 \pm 12$ Ma (B1205, Fig. 12f) to $1132 \pm 6$ Ma (sample B0855; Fig. 12e). The abundance of metamorphic zircon is apparently uncorrelated with the abundance of ilmenite or garnet in the samples, or the abundance of partial melt in the outcrop, such that the available data do not elucidate the zircon forming reactions (Bingen et al., 2001a; Harley et al., 2007; Rubatto et al., 2001; Vavra et al., 1999; Whitehouse and Platt, 2003). Although ages in these six samples overlap within error, the two most robust ones at $1142 \pm 5 \mathrm{Ma}$ (B1204, 13 analyses, Fig. 10j) and $1132 \pm 6 \mathrm{Ma}$ (sample B0855, 14 analyses, Fig. 12e) are nearly distinct and suggest a time span of at least $10 \mathrm{Myr}$ for crystallization of metamorphic zircon in the enderbite Tromøy Complex.

Titanite $\mathrm{U} \mathrm{Pb}$ ages in pegmatite, calc silicate gneiss and quartzofeldspathic gneiss in Bamble mainly range from $1106 \pm 2$ to $1091 \pm 2$ Ma (Cosca et al., 1998; deHaas et al., 2002a). Monazite, titanite and rutile in albitite record at least two phases of metasomatism between $1104 \pm 5$ and $1078 \pm 3 \mathrm{Ma}$ (Engvik et al., 2017; Engvik et al., 2011). Finally, hornblende ${ }^{40} \mathrm{Ar} /{ }^{39} \mathrm{Ar}$ plateau ages, interpreted as cooling ages and collected in samples distributed over the amphibolite and granulite facies domains, range from $1099 \pm 3$ to $1079 \pm 5 \mathrm{Ma}$ (Cosca et al., 1998; Cosca and O'Nions, 1994).

Taken altogether, published and new geochronological data on metamorphism in Bamble indicate coeval metamorphism in the amphibolite and granulite facies domains. They point to two phases of metamorphism. A first phase between 1145 and 1130 Ma includes the peak of amphibolite and granulite facies metamorphism. The second phase between 1105 and 1075 Ma involves fluid rock interaction (metasomatic processes) and regional scale unroofing below amphibolite facies conditions, as defined by titanite and hornblende cooling ages. Intrusion of rare mineral pegmatite bodies (apparently unrelated to any granite plutonism) between $1094 \pm 11 \mathrm{Ma}$ and $1060+8 /-6 \mathrm{Ma}$ (Baadsgaard et al., 1984; Müller et al., 2017; Scherer et al., 2001) overlap with this phase.

\subsection{Bamble Telemarkia boundary}

The Bamble Telemarkia boundary is formed by a narrow Permian fault zone exploiting the $12 \mathrm{~km}$ wide Sveconorwegian ductile to brittle Kristiansand Porsgrunn Shear Zone (Fig. 3; Fig. 7). This shear zone dips to the southeast and is interpreted as a top to the northwest thrust later reactivated as a top to the southeast extensional shear zone (Henderson and Ihlen, 2004; Mulch et al., 2005; Starmer, 1991). Thrust related structures are invariably northwest vergent and formed under amphibolite to upper greenschist facies conditions and are associated with intrusion of tabular pegmatite bodies (Henderson and Ihlen, 2004). Thrusting affected the $1132 \pm 3$ Ma Morkheia monzonite suite mainly exposed on the Telemarkia side of the shear zone (Heaman and Smalley, 1994; Milne and Starmer, 1982), and the $1140 \pm 13$ Ma Hovdefjell Vegårshei augen gneiss mainly exposed on the Bamble side (Touret, 1987) (B1208, Fig. 12j), placing a maximum age for the northwestwards thrusting (Heaman and Smalley, 1994). Extensional shear zones are thin and record greenschist facies conditions. Laser ${ }^{40} \mathrm{Ar} /{ }^{39} \mathrm{Ar}$ data on synkinematic muscovite porphyroblasts in such a shear zone constrain a phase of extension between $891 \pm 3$ and $880 \pm 3$ Ma (Mulch et al., 2005).

\section{Lithosphere generation and distribution}

\subsection{Lithosphere generation at the margin of Fennoscandia}

Continental crust in the Sveconorwegian Orogenic Belt was generated between 1780 and 1480 Ma (Åhäll and Connelly, 2008; Andersen et al., 2004a; Bingen et al., 2005; Petersson et al., 2015b; Roberts and Slagstad, 2015; Roberts et al., 2013). The compilation of available geochronological data on magmatism (Fig. 2) in the orogenic belt unveils a westward decrease in the age of magmatism. The first major magmatic event in each lithotectonic unit is bracketed between 1780 and $1660 \mathrm{Ma}$ for the Eastern Segment, 1660 and $1520 \mathrm{Ma}$ for the Idefjorden Unit, 1575 and 1485 Ma for the Bamble and Kongsberg Units and 1520 and $1480 \mathrm{Ma}$ for the Telemarkia Unit. This age progression is compatible with the incremental genesis of increasingly younger crust 


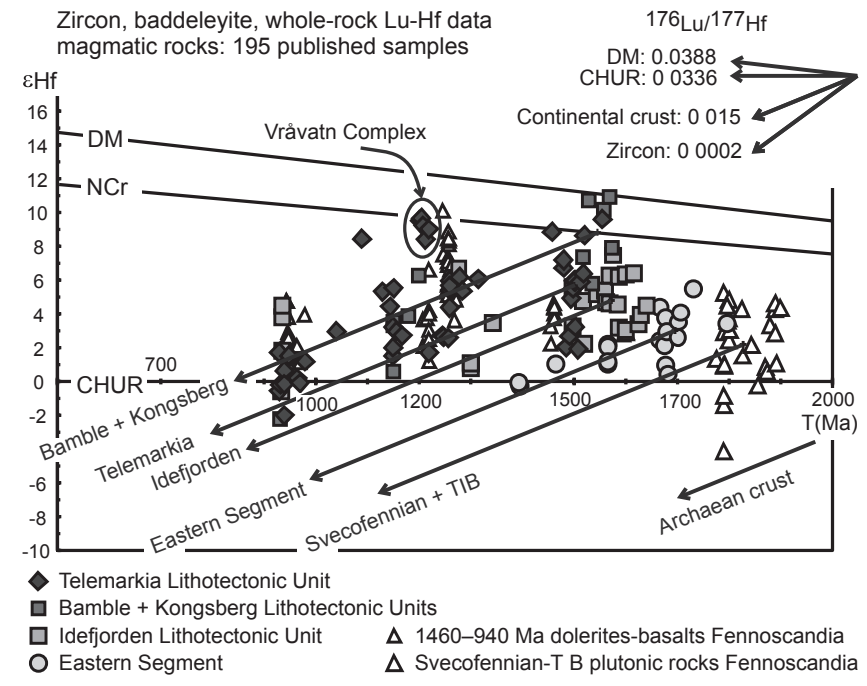

Fig. 18. Lu-Hf isotopic composition expressed as $\varepsilon_{\mathrm{Hf}}$ of magmatic rocks in the Sveconorwegian Orogenic Belt and its foreland, as a function of their intrusion age, from published sources, mainly zircon data. Each symbol represents the average value for one sample, of the isotopic composition of the whole-rock, zircon or baddeleyite and the age of zircon or baddeleyite. Sources of data: Andersen et al. (2009b; 2002; 2007), Pedersen et al. (2009), Petersson et al. (2015a; 2015b), Roberts et al. (2013). DM: depleted mantle (Griffin et al., 2000), NCr: New crust generated in volcanic arc (Dhuime et al., 2011); CHUR: chondritic reservoir (Bouvier et al., 2008). In the top right inset, the ${ }^{176}{ }^{\mathrm{Lu}} /{ }^{177} \mathrm{Hf}$ ratio and evolution vectors of terrestrial reservoirs are shown. The "zircon vector" corresponds to the vector of a typical zircon affected by ap-parent age decrease due to lead loss, without change in the Hf isotopic ratio.

westward along the margin of Fennoscandia in the interval between 1780 and $1480 \mathrm{Ma}$.

The Lu Hf isotopic signature of those magmatic rocks is compiled in Fig. 18. The isotopic signature becomes more radiogenic (increasing $\varepsilon_{\mathrm{Hf}}$ ) westward in the orogenic belt, in the 17801480 Ma time interval, with a clear step across the Mylonite Zone (average $\varepsilon_{\mathrm{Hf}}=3.0$ in the Eastern Segment at $1700 \mathrm{Ma}$ vs. 4.8 in the Idefjorden Unit at $1570 \mathrm{Ma}$, Fig. 18).

Granitoids in the Eastern Segment (1780 $1660 \mathrm{Ma}$ ) have an alkalicalcic to calc alkalic geochemical composition matching the granitoids of the Transcandinavian Igneous Belt (TIB) in the foreland of the Sveconorwegian Orogenic Belt (Appelquist et al., 2011; Appelquist et al., 2008). The genesis of these granitoids is generally interpreted in the context of an Andean supra subduction geodynamic setting. The mildly positive $\varepsilon_{\mathrm{Hf}}$ and $\varepsilon_{\mathrm{Nd}}$ isotopic signature (average $\varepsilon_{\mathrm{Hf}}=3.0$ at $1700 \mathrm{Ma}$; Fig. 18) implies significant recycling of older Paleoproter ozoic (Svecofennian) continental crust in the petrogenesis of this felsic magmatism (Andersen et al., 2009a; Appelquist et al., 2011; Högdahl et al., 2004; Petersson et al., 2015a; Roberts and Slagstad, 2015).

The Gothian 16601520 Ma magmatic suites hosted in the Idefjorden Unit have low to medium $\mathrm{K}$ calc alkalic geochemical com positions (Andersen et al., 2004a; Andersen et al., 2002; Brewer et al., 1998; Petersson et al., 2015b). Metabasalts interlayered in the Stora Le Marstrand rocks are tholeiitic (Brewer et al., 1998). These magmatic suites are interpreted to reflect lithosphere generation in arc and back arc setting. Assembly of arcs and microcontinents took place during the Gothian accretionary orogeny ( $\AA$ häll and Connelly, 2008; Andersen et al., 2004a; Petersson et al., 2015b). Evidence for Gothian regional metamorphism and deformation is rare (Åhäll and Connelly, 1998; Bingen et al., 2008b; Connelly and Åhäll, 1996). However, new data on zircon rims from a garnet biotite gneiss, in Tyristrand (Fig. 5), yield a robust age estimate of $1546 \pm 5$ Ma for Gothian migmatitization in the Veme Complex (sample BBI219, Fig. 15b, Table 1), overlapping with the age of the Hisingen Suite. This date adds to the geochronological evidence from two other localities in the western part of the Idefjorden Unit, where Gothian metamorphic zircon and monazite were dated to $1540 \pm 7$ and $1539 \pm 8 \mathrm{Ma}$ (Åhäll and Connelly, 2008).

In the Kongsberg and Bamble Units, orthogneisses in the 15751460 Ma age interval are characterized by a tholeiitic to low $\mathrm{K}$ calcalkalic signature, and these include the Tromøy Complex (Andersen et al., 2004a; Knudsen and Andersen, 1999). The very low radiometric signal of the Kongsberg Complex on airborne radiometric maps is consistent with this low K signature (K U Th gamma ray; data source: Geological Survey of Norway). The Hf isotopic signature of 1570 and $1530 \mathrm{Ma}$ orthogneisses is very radiogenic, with an average $\varepsilon_{\mathrm{Hf}}=8.8\left(7<\varepsilon_{\mathrm{Hf}}<\right.$ 11), approaching the depleted mantle reservoir (Fig. 18).

In the western part of the Telemarkia Unit, the Telemarkian, 1520 $1480 \mathrm{Ma}$, grey gneisses and granitoids carry a calc alkaline geo chemical signature. They are referred to as the Suldal Arc by Roberts et al. (2013). The Hf isotopic signature is radiogenic with an average $\varepsilon_{\mathrm{Hf}}=5.7$ (Fig. 18) (Pedersen et al., 2009; Roberts et al., 2013). The bimodal Rjukan Group exposed in Telemark (1510 $1495 \mathrm{Ma}$ ) is inter preted to reflect a (back arc) rift setting (the Rjukan rift basin), con tinentwards of the active arc (Köykkä and Lamminen, 2011; Lamminen and Köykkä, 2010; Roberts et al., 2013).

Available data suggest that the four lithotectonic units to the west of the Mylonite Zone were generated in rather juvenile volcanic arc and back arc environment, remote from old Paleoproterozoic continental lithosphere. The variability inside and between these units can be accounted for by a heterogeneously reatreating subduction system or a variable contribution of a metasedimentary component incorporated in the subduction system along the oceanic lower plate (Andersen et al., 2002; Petersson et al., 2015b; Roberts et al., 2013). The isotopic trend in the $17801480 \mathrm{Ma}$ interval, illustrated in Fig. 18, is compatible with the westwards genesis of the lithosphere at the margin of Fennoscandia, although it does not constitute a proof of a Fennoscandia ancestry.

Unquestionable evidence for lithosphere accretion disappears in the Sveconorwegian Orogenic Belt after 1480 Ma. In Fig. 18, each lithotectonic unit in the orogen follows a trend of crustal recycling after continental generation with an average ${ }^{176} \mathrm{Lu} /{ }^{177} \mathrm{Hf}$ ratio of 0.015 (vectors shown in Fig. 18), pointing to limited addition of juvenile material to the crust after $1480 \mathrm{Ma}$. The notable exception is the 12201190 Ma Vråvatn Complex in Telemarkia (discussion below; Fig. 18). Deposition of the c. $8 \mathrm{~km}$ thick quartzite dominated marine sequences of the Seljord, Modum, Nidelva and Kragerø successions at tests to subsidence after c. 1470 Ma (Köykkä and Lamminen, 2011). Deposition of the c. $1 \mathrm{~km}$ thick Jotnian (Dala) sandstone in the same time interval in the foreland of the Sveconorwegian orogen also attests to subsidence of the Fennoscandia Platform (Lundmark and Lamminen, 2016). This subsidence is interpreted as thermal subsidence and de velopment of a sub continental lithospheric mantle keel after accretion (Köykkä and Lamminen, 2011).

In the south, the Hallandian orogenic event (1465 $1370 \mathrm{Ma}$ ) may be the expression of a different, diachronous subduction along the southern margin of Fennoscandia (Ulmius et al., 2015). This would indicate a major change in the geometry of subduction zones around Fennoscandia, from N S trending before 1480 Ma to E W trending after 1465 Ma (Pisarevsky et al., 2014; Ulmius et al., 2015).

\subsection{Early Sveconorwegian relations between lithotectonic units}

The earliest high grade metamorphic event attributed to the Sveconorwegian orogeny is observed exclusively in the Kongsberg and Bamble Units, in the centre of the Sveconorwegian orogen between 1145 and $1130 \mathrm{Ma}$. This central position has inspired geodynamic models involving accretion of an exotic Telemarkia microcontinent to the Idefjorden Unit around $1145 \mathrm{Ma}$, closing an ocean and generating the Bamble Kongsberg orogenic wedge (Bingen et al., 2008c; Bingen et al., 2005). However, three arguments suggest that such models are not correct. 


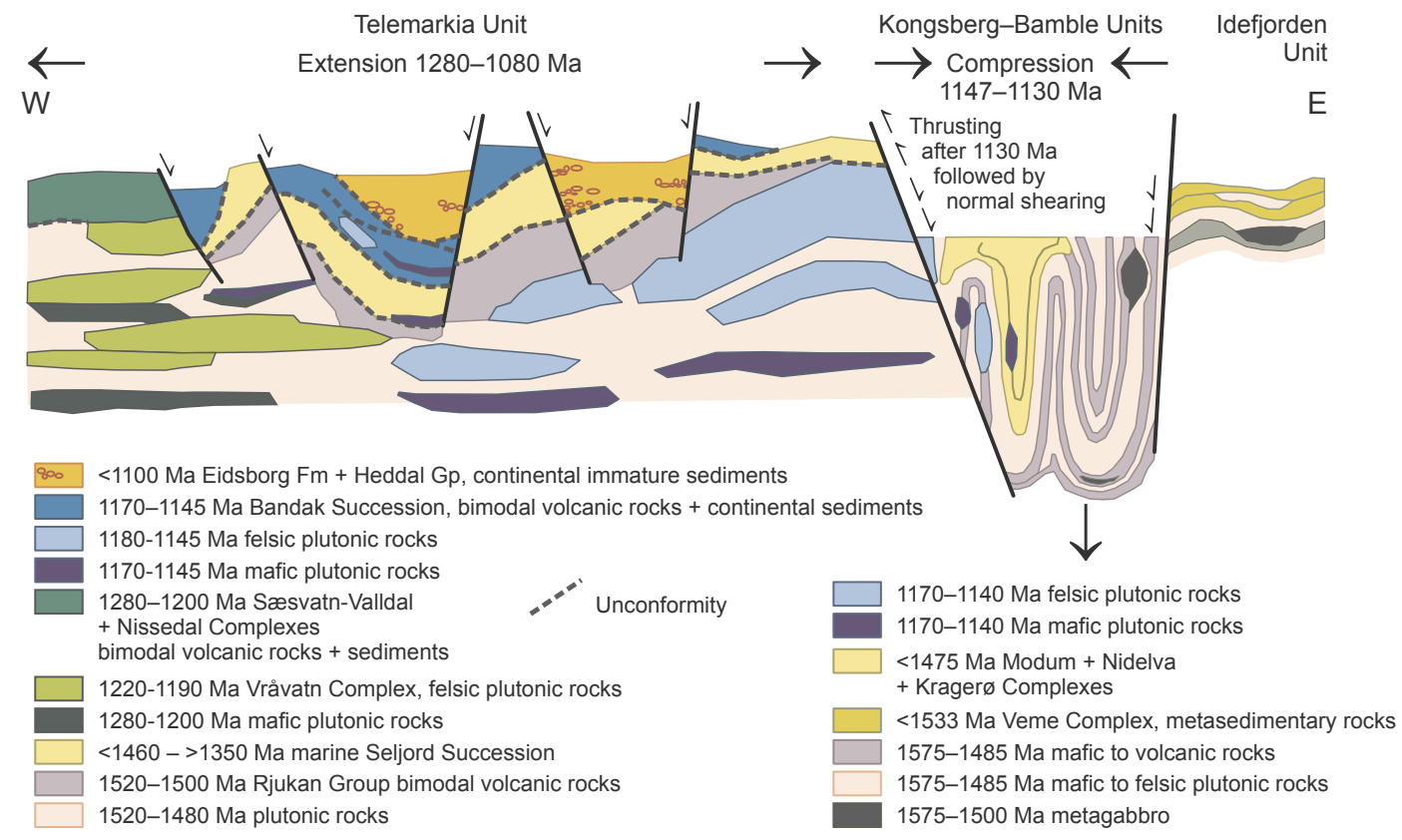

Fig. 19. Conceptual c. $150 \mathrm{~km}$ long E-W cross section through the Idefjorden, Kongsberg and Telemarkia Lithotectonic Units, highlighting the contrast in the earlySveconorwegian geological record between these lithotectonic units around 1150 Ma. Same color coding as in Fig. 3.

(i) An important overlap exists in the age of magmatism between the four western lithotectonic units of the orogenic belt. Indeed, the 15201480 Ma magmatic suites characteristic of Telemarkia are becoming increasingly recorded over the Bamble, Kongsberg and Idefjorden Units, as more data become available (Fig. 2). Especially prominent in the data from this study, is the abundance of 15201480 Ma magmatism in the Kongsberg Unit. The overlap weakens the geochronological argument to suggest that these four units formed at the margin of distinct lithospheric plates and that an early Sveconorwegian suture zone somewhere stitches them.

(ii) On the basis of pionering geochronological data, the low $\mathrm{K}$ calcalkaline Tromøy Complex in Bamble was interpreted as an early Sveconorwegian, c. $1200 \mathrm{Ma}$, oceanic volcanic arc (Andersen et al., 2004a; Andersen et al., 2002; Knudsen and Andersen, 1999). These data implied an oceanic tract in the middle of the orogen, therefore supporting the accretion model (Andersen et al., 2004a). New data of representative samples of the low $\mathrm{K}$ suite in Tromøy, however, unambiguously demonstrate magmatic protolith between $1575 \pm 44$ and $1544 \pm 14$ Ma (Figs. 10 and 12, Table 1), thus dismissing the idea of an early Sveconorwegian ocean closure in the middle of Sveconorwegian Orogenic Belt.

(iii) Clastic sediments deposited after $1260 \mathrm{Ma}$ in the Telemarkia Unit, including the Sæsvatn Valldal and Bandak successions, contain minor populations of Paleoproterozoic and Archaean detrital zircon (Fig. 4) (Bingen et al., 2002, 2003; Lamminen, 2011; Spencer et al., 2014). This supports distal sourcing from old con tinental catchments located to the west of the exposed orogen, arguing in favour of an exotic origin of the Telemarkia Unit, and docking to the rest of the orogen at around $1145 \mathrm{Ma}$ (Bingen et al., 2001b). However, comparison of detrital zircon distributions be tween marine sediments deposited between 1470 and 1350 Ma (Seljord and Modum successions; Bingen et al., 2001b; Lamminen and Köykkä, 2010) and continental sediments deposited after $1260 \mathrm{Ma}$ (Sæsvatn Valldal and Bandak successions; Bingen et al., 2002, 2003; Lamminen, 2011; Spencer et al., 2014), suggests im portant recycling between these two generations of sediments (Fig. 4). The influx of extraneous Paleoproterozoic and Archaean detrital zircon in the west of the orogen therefore took place be tween 1470 and 1350 Ma assisted by marine currents. The ultimate source of these zircon clasts remains enigmatic (Lamminen and Köykkä, 2010; Lundmark and Lamminen, 2016). However, their presence in Telemarkia bears no information relevant for the Sveconorwegian tectonic evolution.

The position of the Bamble and Kongsberg Units has also inspired geotectonic models involving long distance strike slip transport of the Telemarkia Unit relative to the Idefjorden Unit, at the margin of Fennoscania, generating a Bamble Kongsberg transpressional shear belt (Bingen et al., 2008c; Lamminen and Köykkä, 2010). However, as de scribed hereabove, none of the tectonic boundaries between the Bamble, Kongsberg, Telemarkia and Idefjorden Units, nor the core of the Bamble and Kongsberg Units, exhibit signs of significant wrench tectonics, thus excluding large strike slip transport. A component of sinistral strike slip shearing is recorded by mylonites in the Kongsberg Unit (Scheiber et al., 2015), but these are compatible with transpres sional deformation ensuing only after the peak of orthogonal de formation and high grade metamorphism.

To conclude, available geochronological and isotopic data suggest that the four units situated to the west of the Mylonite Zone were approximatively in their present day relative position already before the Sveconorwegian orogeny. They were neither separated by oceans, nor separated by long distances at the same margin of Fennoscandia.

Instead, a clear separation is visible in Figs. 2 and 18 between the Eastern Segment and the western part of the orogen. The implication is that the only possible Sveconorwegian suture zone might correspond to the Mylonite Zone (Petersson et al., 2015b). However, according to the existing metamorphic record, this suturing would pertain only to the post 1050 Ma orogenic evolution (Möller et al., 2015).

\section{Gravitational instability of the sub-continental lithospheric mantle}

\subsection{Concept}

An evaluation of the composition, temperature and density profile of the lithosphere through geological time supports the concept that, on average, the sub continental lithospheric mantle was denser in the Proterozoic than in the Phanerozoic and also that it was denser than the 


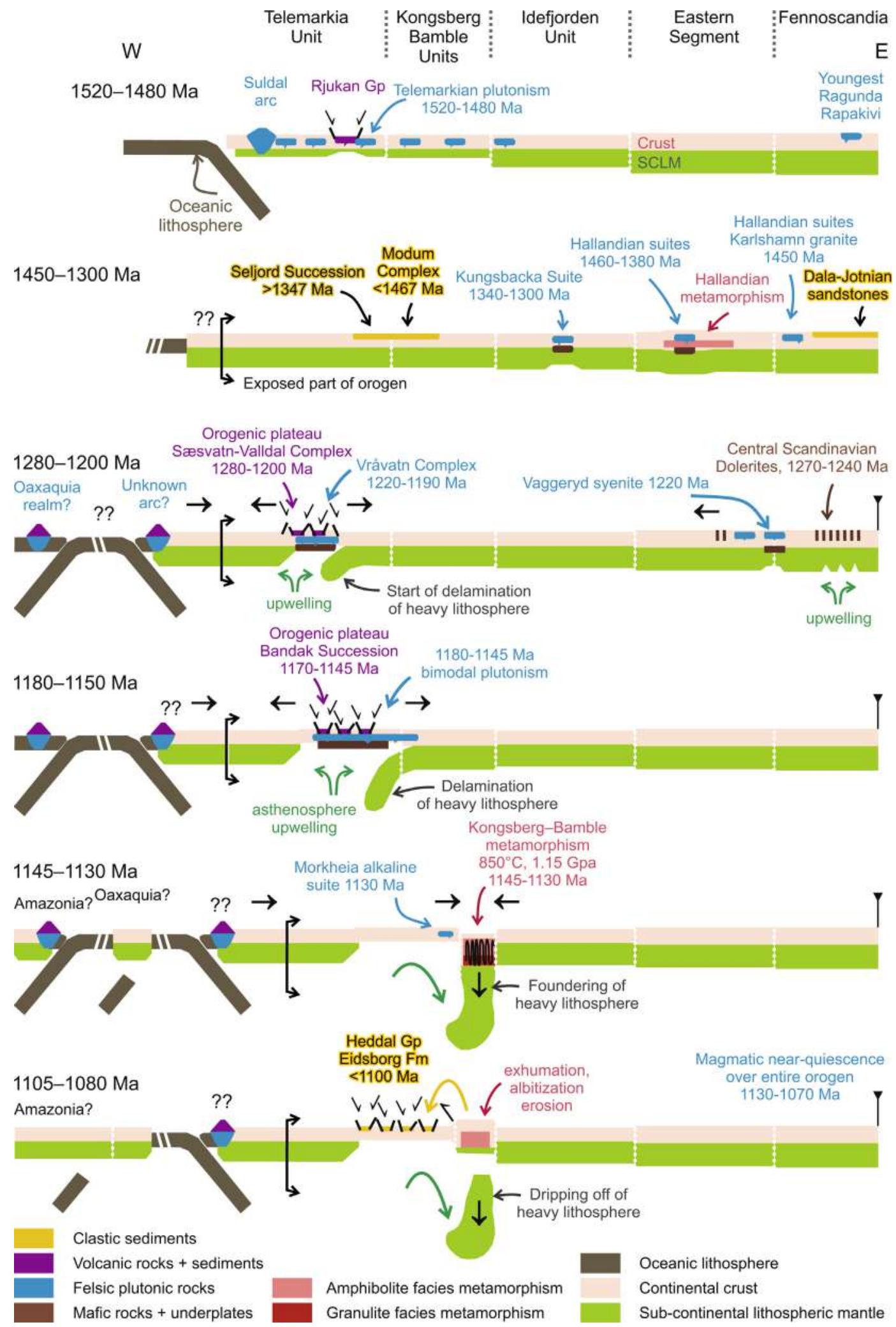

Fig. 20. Conceptual c. $700 \mathrm{~km}$ wide E-W cross sections of the Sveconorwegian Orogenic Belt representing the pre- to early-Sveconorwegian geodynamic evolution between c. 1520 and 1080 Ma. The sections illustrate the concept of delamination of the continental lithospheric mantle under the Telemarkia Unit between 1280 and $1145 \mathrm{Ma}$ followed by foundering under the Kongsberg and Bamble Units between 1145 and $1130 \mathrm{Ma}$. The evolution of westernmost part of the orogen, not exposed today, is inspired from Weber et al. (2010) and Ibanez-Mejia et al. (2011), in the hypothesis of a Fennoscandia-Amazonia collision around 1070 Ma with an intervening Oaxaquia- Garzón microcontinent. 
asthenosphere (Griffin et al., 2009; Poudjom Djomani et al., 2001). This implies that the Proterozoic continental lithospheric mantle was gravitationally unstable and prone to sinking if decoupled from the over lying continental crust (Bird, 1979). In the model presented below, this instability is used to propose a model for the early Sveconorwegian geodynamic evolution.

The available dataset shows a stark contrast in the geological record for the $12801080 \mathrm{Ma}$ time interval in the Telemarkia, Kongsberg Bamble and Idefjorden Units (Fig. 19). The record documents abundant bimodal magmatism and protracted (upper) crustal extension in Telemarkia without any evidence of shortening in the time interval between 1280 and $1050 \mathrm{Ma}$. In contrast, high grade meta morphism and shortening is observed coevally in the Kongsberg Bamble Units between 1147 and 1130 Ma (Fig. 19). Furthermore, the Idefjorden Unit lacks evidence for any of the 1280 $1145 \mathrm{Ma}$ bimodal magmatism (Fig. 19) or $1147 \quad 1130 \mathrm{Ma}$ metamorphism and compres sion, and therefore was not involved in this early Sveconorwegian evolution.

As illustrated in Fig. 20, we propose that paired extension in Telemarkia and compression in Kongsberg Bamble can be accounted for by a model of within plate, slowly evolving destabilisation of the subcontinental lithosphere. Upwelling of hot astenospheric mantle would have started at c. 1280 Ma beneath Telemarkia, thereby triggering progressive delamination of the lithosphere, i.e. decoupling between the light crust and the heavy/cold continental lithospheric mantle (Dewey, 1988). Delamination of the lithospheric mantle continued until $1150 \mathrm{Ma}$ and affected a progressively larger area. Foundering (drip ping off) of the lithospheric mantle slab took place below the Kongs berg Bamble Units. We suggest that the pull effect of foundering was the motor for high grade metamorphism and deformation in Kongs berg Bamble between 1145 and $1130 \mathrm{Ma}$, before slab breakoff trig gered exhumation after $1130 \mathrm{Ma}$.

\subsection{Upwelling of the asthenosphere beneath Telemarkia}

Evidence for upwelling and decompression melting of hot asthe nospheric mantle under Telemarkia is provided by the repeated pulses of within plate bimodal magmatism (plutonism and volcanism) be tween 1280 and $1145 \mathrm{Ma}$ (Figs. 2; 13a f; Table 1).

Basalts in the Sæsvatn Valldal Complex, extruded after c. $1260 \mathrm{Ma}$, have a depleted mantle Nd isotopic signature $\left(2.6<\varepsilon_{\mathrm{Nd}}<6.3\right)$ (Brewer et al., 2004). The voluminous felsic gneisses of the Vråvatn Complex, intruded between 1220 and $1190 \mathrm{Ma}$, have a within plate granitic geochemical signature. The $\mathrm{Hf}$ isotopic signature of zircon is characterized by an average $\varepsilon_{\mathrm{Hf}}$ ranging from 9 to 10 (four samples), approaching the depleted mantle reservoir at $1210 \mathrm{Ma}\left(\varepsilon_{\mathrm{Hf}}=12\right)$ (Fig. 18) (Andersen et al., 2007). These values indicate that the Vråvatn Complex was not generated by partial melting of the $15201480 \mathrm{Ma}$ crust. Rather, it formed by fractionation of a depleted, mantle derived basalt (akin the Nissedal and Sæsvatn Valldal basalts) or by partial melting of a mafic underplate, itself produced shortly before in the depleted mantle ( $<50 \mathrm{Myr}$ before $1210 \mathrm{Ma}$; Andersen et al., 2007). The mafic volcanic rocks in the Bandak Succession (Morgedal and Gjuve metabasalts), extruded around $1150 \mathrm{Ma}$, have a within plate geochemical signature. They have a Nd isotopic signature $\left(4.1<\varepsilon_{\mathrm{Nd}}<\right.$ 5.0, Gjuve metabasalt) approaching the depleted mantle reservoir, therefore also pointing to a depleted asthenospheric source around 1150 Ma (Brewer et al., 2002; Spencer et al., 2014). The de pleted mantle $\mathrm{Hf}$ and $\mathrm{Nd}$ isotopic signature of these magmatic suites imply sourcing of basaltic magmas in the asthenosphere, at least epi sodically between 1260 and 1150 Ma.

The magmatism between 1280 and 1190 Ma is mainly located in the center of the Telemarkia Unit (Vråvatn, Nissedal, Sæsvatn Valldal, Iveland Gautestdad areas, Fig. 3) whereas the younger magmatism between 1170 and 1145 Ma affected the periphery of the Telemarkia Unit and partly extended into the Kongsberg and Bamble Units. This geographic distribution suggests indeed that the zone affected by up welling broadened with time, as proposed in the model of Fig. 20.

Extended ponding of mafic and felsic magmas bodies at the mantle crust interface further enhanced decoupling between the crust and underlying lithospheric mantle and therefore initiated delamination of the cold/ heavy lithospheric mantle as early as $1260 \mathrm{Ma}$.

\subsection{Extensional orogenic plateau in Telemarkia}

The testable effect of progressive decoupling between light crust and heavy lithospheric mantle is uplift of the crust, development of topography and formation of an orogenic plateau in extension (Corrigan and Hanmer, 1997; Dewey, 1988; Gray and Pysklywec, 2012; Molnar et al., 2015). Evidence for a tectonically active plateau in Tel emarkia between 1260 and $1080 \mathrm{Ma}$ is provided by the sedimentology and facies associations of continental low grade sedimentary rocks de posited from $1210 \mathrm{Ma}$ to after $1100 \mathrm{Ma}$.

The sediments of the Bandak Succession are generally high energy immature to conglomeratic fluvial deposits, local massflow conglomerates and thin lacustrine mudstones. They are interpreted as alluvial fan , braided fluvial and locally eolian deposits, accumulated in continental intermontane basins (Bingen et al., 2003; Cosentino et al., 2017; Köykkä, 2011; Lamminen, 2011; Spencer et al., 2014). The lim ited lateral extent of the sedimentary rock bodies and the existence of at least two internal unconformities in the Bandak Succession imply active tectonism during its progressive accumulation (Laajoki, 2002; Laajoki et al., 2002). Importantly, the study of one of the basin of the Eidsborg Formation (Snaunetten basin accumulated after c. $1100 \mathrm{Ma}$ ), unconformably overlying the Rjukan Group on one side and the Seljord Succession on the other side, reveals that the clast assemblage in the alluvial fan conglomerate deposits changes with the actual stratigraphic position (Lamminen, 2011). The progression from a polymict conglomerate near the base to monomict conglomerates dominated by rhyolite clasts sourced in the Rjukan Group, and finally to monomict conglomerates dominated by quartzite clasts sourced in the Seljord Succession, implies that the bordering normal faults were synsedimentary growth faults, as typically the case for a fault bounded intermontane extensional basin (Lamminen, 2011). Geochronological relations between the Seljord and Bandak Successions along the shore of Seljordvatnet, as illustrated in Fig. 14b, are also compatible with normal faulting around c. 1160 Ma inverted into a reverse shear zone after 1050 Ma.

\subsection{Foundering of the lithospheric mantle underneath Bamble and Kongsberg}

Foundering of the lithospheric mantle underneath the Bamble and Kongsberg Units is testified by what we interpret as evidence for sag duction of the crust between 1145 and 1130 Ma (Figs. 19 and 20). Two lines of evidence support this:

i. The amphibolite to granulite facies metamorphism in Bamble and Kongsberg yields peak pressure estimates between 0.6 and $1.15 \mathrm{GPa}$ (Engvik et al., 2016; Harlov, 2000; Nijland et al., 2014). The max imum estimate of $1.15 \mathrm{GPa}$ implies crustal thickening up to at least $40 \mathrm{~km}$ for rocks exposed today at the surface. A steep foliation distributed at the scale of the entire Units, highly transposed litholo gical banding and tight to isoclinal folding are best explained by orthogonal shortening oriented E W for Kongsberg and NW SE for Bamble, coeval with metamorphism. Commonly steep lineations on the steep foliation planes suggest a component of near vertical stretching or near vertical transport in the crust (Figs. 16 and 17).

ii. The timing of metamorphism in the Bamble and Kongsberg Units (1145 $1130 \mathrm{Ma}$ ) overlaps with the final stage of bimodal magmatism around $1145 \mathrm{Ma}$ and the alkaline magmatism at $11341130 \mathrm{Ma}$ (Morkheia monzonite suite) in the Telemarkia Unit (Fig. 2). Also, 
metamorphism overlaps with the intrusion of gabbroic, granitic and charnockitic plutons inside the Kongsberg and Bamble Units be tween 1152 and 1140 Ma (Fig. 2; Table 1). This spatial and temporal coincidence implies that charnockitic magmas were sourced in the granulite facies lower crust, while crustal thickening, deformation and sagduction took place.

The timing of continental lithospheric mantle slab(s) breakoff is best estimated at the end of prograde granulite facies metamorphism, around $1130 \mathrm{Ma}$. There is no evidence that the Idefjorden Unit was affected by slab pull or related forces between 1145 and 1130 Ma. We conclude, therefore, that the shear zone making the boundary between the Kongsberg and Idefjorden units is a lithospheric scale structure that effectively bounded and inhibited further eastward propagation of the slab foundering at this point in time.

\subsection{Exhumation and fluid rock interaction in Kongsberg and Bamble}

After the inferred slab breakoff, the Bamble and Kongsberg Units were exhumed to upper crustal levels and were only weakly affected by younger Sveconorwegian orogenic phases (Fig. 20). The rate and pressure temperature path of this rebound are not yet well constrained. The timing is bracketed between 1105 and $1080 \mathrm{Ma}$, as suggested by titanite and monazite $\mathrm{U} \mathrm{Pb}$ data and hornblende ${ }^{40} \mathrm{Ar} /{ }^{39} \mathrm{Ar}$ data (Bingen et al., 2008c; Cosca et al., 1998). Exhumation was associated with northwestwards thrusting of Bamble along the Kris tiansand Porsgrunn Shear Zone and westwards thrusting of the Kongsberg along the Saggrenda Sokna Shear Zone and reworking of plutons formed shortly before the foundering process (Henderson and Ihlen, 2004; Scheiber et al., 2015). The Kongsberg and Bamble Units underwent further later deformation during exhumation, as docu mented by several amphibolite facies high strain zones, some showing a sinistral shear component in response to local obliquity (Scheiber et al., 2015). Exhumation and erosion of the Bamble and Kongsberg Units after 1105 Ma probably fed part of the sedimentation observed in the Heddal Group and Eidsborg Formation (Figs. 4 and 20).

One peculiar aspect of the exhumation of the Kongsberg and Bamble Units is that it was associated with widespread metasomatism, including scapolitization and albitization, between 1105 and $1080 \mathrm{Ma}$ (Austrheim et al., 2008; Engvik et al., 2017; Engvik et al., 2011; Munz et al., 1994), and fluid rich pegmatite genesis and emplacement be tween 1095 and $1060 \mathrm{Ma}$ (Müller et al., 2017). Albitization took place below $550{ }^{\circ} \mathrm{C}$ (Engvik et al., 2017) and involved remarkable mobiliza tion of $\mathrm{Na}, \mathrm{Cl}, \mathrm{Mg}, \mathrm{Ca}, \mathrm{K}, \mathrm{P}$ and $\mathrm{B}$ (Bast et al., 2014). Ratios of $\mathrm{Cl}, \mathrm{Br}$ and I concentrations in albitite replacing gabbro suggest that the fluids responsible for the metasomatic reactions derived from marine sediments of the Kragerø and Nidelva Complexes, rather than putative evaporite layers or a mantle reservoir (Kusebauch et al., 2015). How liberation of these fluids relates to slab breakoff and rebound of the crust as shown in Fig. 20 is, however, an open question.

\section{Plate tectonic interpretation in a Rodinia context}

The within plate delamination foundering model summarized in Fig. 20 suggests that destabilisation of the lithosphere in the Sveconorwegian Orogenic Belt started at $1280 \mathrm{Ma}$, that is, only $200 \mathrm{Myr}$ after the lithosphere had been generated. Destabilisation initiated in the west of the orogen where the lithosphere was the youngest and most juve nile. The continent scale paleogeography and plate tectonic context of this destabilisation (Fig. 20) and its connection to Rodinia assembly is speculative. Paleomagnetic data that could constrain the paleogeographic framework remain notably scanty for the Mesoproterozoic (Cawood and Pisarevsky, 2017; Pisarevsky et al., 2014). Following the discussion hereabove, three geodynamic scenarios are possible:

i. Coeval extension and compression in Telemarkia and
Kongsberg Bamble, respectively, imply that compressive stresses in Kongsberg Bamble were not due to a far field plate configuration at the boundary of the orogen. The delamination foundering model of Fig. 20 would instead represent a robust example of intraplate vertical tectonics (Raimondo et al., 2014). Such a process was successfully simulated numerically by Gorczyk et al. (2013) and Ueda et al. (2008), and would be largely unrelated to the assembly of Rodinia.

ii. Lithospheric mantle delamination and foundering can take place in the central part of large collisional orogens (Dewey, 1988). This process has been discussed for the Himalaya Tibet collision zone in many publications (Chen et al., 2017; DeCelles et al., 2002). Fol lowing this idea, collision between Fennoscandia and another plate (Amazonia) could have started as early as $1280 \mathrm{Ma}$ initiating lithospheric mantle delamination and continued in several phases between 1280 and $900 \mathrm{Ma}$. This would make the Sveconorwegian orogeny an extremely slow collision orogeny.

iii. The tectonic stages preceding a continent collision involve closure of oceanic basins between the involved continents and can be characterized by subduction of old (heavy) oceanic lithosphere, resulting in a retreating subduction boundary and extension in the overlying plate (e.g. Royden, 1993). In this context, the Tele markia Bamble Kongsberg units could be located, together, in a continental back arc position on the continent side (Fennoscandia) of an active volcanic arc (Göğüş, 2015; Roberts and Slagstad, 2015; Slagstad et al., 2017; Spencer et al., 2014). This arc is unknown (not exposed) and was presumably located west of the orogen. It might have disappeared by tectonic erosion (Spencer et al., 2014). There is no evidence to suggest that the subduction system around 12801190 Ma would be a continuation of the one around 1500 Ma (Fig. 20). The delamination foundering model of Fig. 20 could mark a cycle of retreating subduction between 1280 and 1145 Ma (evi dence for extension in back arc area) followed by a cycle of ad vancing subduction between 1145 and 1130 Ma (evidence for coeval extension and compression in the back arc area). The western part of Amazonia contains a record of early Grenvillian (1180 $1150 \mathrm{Ma}$ ) metamorphism (Sunsas orogen and Ji Paraná shear zone network) (Tohver et al., 2005; Tohver et al., 2002) and it is therefore a realistic conjugate margin for the Sveconorwegian orogen. Several studies underscore the geological and isotopic affinity between the Telemarkia Unit and several Mesoproterozoic terranes reconstructed in the periphery of Amazonia, including the inliers in the Andes of Columbia (Garzón massif), inliers in Mexico (Oaxaquia) and basement to Andean foreland basin (Putumayo) (Cameron et al., 2004; Ibanez Mejia et al., 2015; Ibanez Mejia et al., 2011; Keppie and Ortega Gutiérrez, 2010; Weber et al., 2010). These terranes contain evidence of high grade metamorphism between 1050 and $990 \mathrm{Ma}$, coeval with si milar conditions in Telemarkia, and can potentially be restored paleogeographically between Fennoscandia and Amazonia, to the west of the Sveconorwegian orogen. To account for this possibility, the western part of the model of Fig. 20 is inspired from Weber et al. (2010) and Ibanez Mejia et al. (2011), and thus contains the Oaxaquia Garzón microcontinent that was first accreted to Amazonia before ending in a lower plate position during the collision with Fennoscandia around 1050 Ma. In this framework, the Telemarkia Kongsberg Bamble units are indeed situated in a back arc domain, in the time interval between 1280 and $1080 \mathrm{Ma}$, before closure of all oceans.

The sequence of events described for the Telemarkia Kongsberg Bamble Units between 1280 and $1080 \mathrm{Ma}$ is interpreted in Fig. 20 as a single cycle of asthenosphere upwelling, followed by delamination and foundering of the lithospheric mantle and relaxation. Independently of the plate tectonic interpretation, the $\mathrm{c}$. 200 Myr duration of this sequence suggests a slow evolution, which is in sharp contrast with the pace of tectonic events recorded in Phanerozoic orogens. For example, the cycle of plateau development and foundering 
of the lithosphere has allegedly taken place in the Himalaya Tibet collision zone during the last $25 \mathrm{Myr}$ (Chen et al., 2017; DeCelles et al., 2002; Zhao et al., 2009). The slow rate or long duration of individual orogenic phases and of the entire orogeny in the Grenville orogen (Carr et al., 2000; Hynes and Rivers, 2010; Rivers, 2008), and the Sveco norwegian orogen (Bingen et al., 2008c; this work), is a paradox. It can not be explained simply by the low resolution of the available geo-chronological data or a fragmentary preservation of the geological re cord in the Precambrian orogens, but must be a genuine signature (Viola et al., 2011).

\section{Conclusions}

Based on our new data and on the review of the literature, we propose that:

i. The distribution of geochronological and isotope data at the scale of the Sveconorwegian Orogenic Belt favors a model of westward continental lithosphere accretion in a subduction environment at the margin of Fennoscandia between 1780 and $1480 \mathrm{Ma}$. Subduction ceased after $1480 \mathrm{Ma}$, after which it may have moved to the southern margin of Fennoscandia (Hallandian orogeny). Relaxation of the lithosphere after 1480 Ma was characterized by subsidence, transgression and marine sedimentation incorporating in the orogen far travelled detrital zircon clasts.

ii. The pre to early Sveconorwegian geological record for the interval between 1280 and $1080 \mathrm{Ma}$ is very different in the Telemarkia, Kongsberg Bamble and Idefjorden Units, that were by then tectonically juxtaposed. Telemarkia was characterized by episodic bimodal magmatism with a depleted mantle isotopic signature be tween 1280 and $1145 \mathrm{Ma}$, crustal extension and intermontane basin sedimentation between 1280 and $1080 \mathrm{Ma}$. The Kongsberg and Bamble Units, instead, underwent medium pressure (up to $1.15 \mathrm{GPa}$ ) amphibolite to granulite facies metamorphism between 1145 and $1130 \mathrm{Ma}$, associated with development of highly transposed lithological banding and fabrics containing a commonly steep lineation, recording orthogonal shortening, followed by exhumation after $1105 \mathrm{Ma}$. The Idefjorden Unit was not affected by any of these events. Paired extension compression in a Sveconorwegian con vergent orogen is readily accounted for by a model of asthenosphere upwelling, orogenic plateau development and delamination of the continental lithospheric mantle under Telemarkia, followed by foundering (dripping off) of the lithospheric mantle slab under Kongsberg Bamble (Fig. 20). The model underscores the pull effect of the foundering mantle slab to generate compression and granu lite facies metamorphism in the sagging crust. It also implies that the early Sveconorwegian orogenic phase does not correspond to the accretion of an exotic Telemarkia microcontinent. We speculate that the protracted (1280 $1130 \mathrm{Ma}$ ) delamination foundering evolution took place in a back arc position, continentwards of an (un known) volcanic arc, before the main collision that led to the as sembly of Rodinia.

iii. The proposed model of asthenosphere upwelling, followed by delamination and foundering of the lithospheric mantle evolved slowly between 1280 and 1080 Ma. Such slow evolution rate seems to be a genuine property of Grenvillian orogenic belts.

\section{Acknowledgements}

This study is an outcome of the Kongsberg Modum mapping project, funded by the Geological Survey of Norway and the "Buskerud Telemark Vestfold Fylkeskommuner". S. Dahlgren secured funding from the counties. T. Bjerkgård, I.H.C. Henderson, J.S. Sandstad, T. Scheiber, H. Schiellerup, A. Solli, and E. Torgersen contributed to mapping in Kongsberg, V.C. Baranwal assembled the geophysical data, and A Jarna manages de geochronology databases. SIMS data were collected at the
NORDSIMS laboratory at the Swedish Museum of Natural History, thanks to M.J. Whitheouse, L. Ilyinsky and K. Lindén. LA ICP MS data were collected at the Geological Survey of Norway, thanks to T. Røhr and $\emptyset$. Skår. Two anonymous reviewers and the editor, R.R. Parrish, provided detailed constructive comments. This is NORDSIMS publication \#559.

Declarations of interest.

none.

\section{Appendix A. Supplementary data}

Supplementary data associated with this article can be found, in the online version, at http://dx.doi.org/10.1016/j.precamres.2018.05.025. These data include Google maps of the most important areas described in this article.

\section{References}

Åhäll, K.I., Connelly, J.N., 1998. Intermittent 1.53-1.13 Ga magmatism in western Baltica; age constraints and correlations within a postulated supercontinent. Precambr. Res. 92, 1-20.

Åhäll, K.I., Connelly, J.N., 2008. Long-term convergence along SW Fennoscandia: 330 m.y. of Proterozoic crustal growth. Precambr. Res. 161, 452-474.

Åhäll, K.I., Cornell, D.H., Armstrong, R., 1998. Ion probe zircon dating of metasedimentary units across the Skagerrak: new constraints for early Mesoproterozoic growth of the Baltic Shield. Precambr. Res. 87, 117-134.

Åhäll, K.I., Gower, C.F., 1997. The Gothian and Labradorian orogens: variations in accretionary tectonism along a late Paleoproterozoic Laurentia-Baltica margin. Geol. Foeren. Stockholm Foerh. 119, 181-191.

Åhäll, K.I., Larson, Å., 2000. Growth-related 1.85-1.55 Ga magmatism in the Baltic

Shield; a review addressing the tectonic characteristics of Svecofennian, TIB 1 -re-lated, and Gothian events. Geol. Foeren. Stockholm Foerh. 122, 193-206.

Andersen, T., Griffin, W.L., Pearson, N.J., 2002. Crustal evolution in the SW part of the Baltic Shield: the Hf isotope evidence. J. Petrol. 43, 1725-1747.

Andersen, T., Griffin, W.L., Jackson, S.E., Knudsen, T.L., Pearson, N.J., 2004a. MidProterozoic magmatic arc evolution at the southwest margin of the Baltic shield. Lithos 73, 289-318.

Andersen, T., Griffin, W.L., Sylvester, A.G., 2007. Sveconorwegian crustal underplating in southwestern Fennoscandia: LAM-ICPMS U-Pb and Lu-Hf isotope evidence from granites and gneisses in Telemark, southern Norway. Lithos 93, 273-287.

Andersen, T., Andersson, U.B., Graham, S., Åberg, G., Simonsen, S.L., 2009a. Granitic magmatism by melting of juvenile continental crust: new constraints on the source of Palaeoproterozoic granitoids in Fennoscandia from Hf isotopes in zircon. J. Geol. Soc. London 166, 233-247.

Andersen, T., Graham, S., Sylvester, A.G., 2009b. The geochemistry, Lu-Hf isotope systematics, and petrogenesis of late Mesoproterozoic A-type granites in southwestern Fennoscandia. Can. Mineral. 47, 1399-1422.

Andersen, T., Grorud, H.F., 1998. Age and lead isotope systematics of uranium-enriched cobalt mineralization in the Modum complex, South Norway; implications for Precambrian crustal evolution in the SW part of the Baltic Shield. Precambr. Res. 91, 419-432.

Andersen, T., Laajoki, K., Saeed, A., 2004b. Age, provenance and tectonostratigraphic status of the Mesoproterozoic Blefjell quartzite, Telemark sector, southern Norway.

Precambr. Res. 135, 217-244.

Andersson, J., Möller, C., Johansson, L., 2002. Zircon chronology of migmatite gneisses along the Mylonite Zone (S Sweden): a major Sveconorwegian terrane boundary in the Baltic Shield. Precambr. Res. 114, 121-147.

Appelquist, K., Cornell, D., Brander, L., 2008. Age, tectonic setting and petrogenesis of the Habo Volcanic Suite: evidence for an active continental margin setting for the Transscandinavian Igneous Belt. Geol. Foeren. Stockholm Foerh. 130, 123-138.

Appelquist, K., Brander, L., Johansson, Å., Andersson, U.B., Cornell, D., 2011. Character and origin of variably deformed granitoids in central southern Sweden: implications from geochemistry and Nd isotopes. Geol. J. 46, 597-618.

Årebäck, H., Andersson, U.B., Petersson, J., 2008. Petrological evidence for crustal melting, unmixing, and undercooling in an alkali-calcic, high-level intrusion: the late Sveconorwegian Vinga intrusion, SW Sweden. Mineral. Petrol. 93, 1-46.

Austin Hegardt, E., Cornell, D.H., Hellström, F.A., Lundqvist, I., 2007. Emplacement age of the mid-Proterozoic Kungsbacka Bimodal Suite, SW Sweden. Geol. Foeren. Stockholm Foerh. 129, 227-234.

Austrheim, H., Putnis, C.V., Engvik, A.K., Putnis, A., 2008. Zircon coronas around Fe-Ti oxides: a physical reference frame for metamorphic and metasomatic reactions. Contrib. Miner. Petrol. 156, 517-527.

Baadsgaard, H., Chaplin, C., Griffin, W.L., 1984. Geochronology of the Gloserheia pegmatite, Froland, southern Norway. Nor. Geol. Tidsskr. 64, 111-119.

Bast, R., et al., 2014. Boron isotopes in tourmaline as a tracer of metasomatic processes in the Bamble sector of Southern Norway. Contrib. Miner. Petrol. 168, 1069.

Berthelsen, A., 1980. Towards a palinspastic tectonic analysis of the Baltic Shield. In: Cogne, J., Slansky, M. (Eds.), Geology of Europe, From Precambrian to the PostHercyninan Sedimentary Basins. Mémoires, Mémoires du B.R.G.M., Paris, pp. 5-21.

Bingen, B., et al., 2005. Timing of continental building in the Sveconorwegian orogen, SW Scandinavia. Norw. J. Geol. 85, 87-116.

Bingen, B., Austrheim, H., Whitehouse, M.J., 2001a. Ilmenite as a source for zirconium during high-grade metamorphism? Textural evidence from the Caledonides of W. 
Norway and implications for zircon geochronology. J. Petrol. 42, 355-375.

Bingen, B., Birkeland, A., Nordgulen, Ø., Sigmond, E.M.O., 2001b. Correlation of supracrustal sequences and origin of terranes in the Sveconorwegian orogen of SW Scandinavia: SIMS data on zircon in clastic metasediments. Precambr. Res. 108, 293-318.

Bingen, B., Nordgulen, Ø., Viola, G., 2008c. A four-phase model for the Sveconorwegian orogeny, SW Scandinavia. Norw. J. Geol. 88, 43-72.

Bingen, B., Andersson, J., Söderlund, U., Möller, C., 2008a. The Mesoproterozoic in the Nordic countries. Episodes 31, 29-34.

Bingen, B., van Breemen, O., 1998. U-Pb monazite ages in amphibolite- to granulite-facies orthogneisses reflect hydrous mineral breakdown reactions: Sveconorwegian Province of SW Norway. Contrib. Miner. Petrol. 132, 336-353.

Bingen, B., Mansfeld, J., Sigmond, E.M.O., Stein, H.J., 2002. Baltica-Laurentia link during the Mesoproterozoic: $1.27 \mathrm{Ga}$ development of continental basins in the Sveconorwegian Orogen, southern Norway. Can. J. Earth Sci. 39, 1425-1440.

Bingen, B., Nordgulen, Ø., Sigmond, E.M.O., Tucker, R.D., Mansfeld, J., Högdahl, K., 2003. Relations between 1.19-1.13 Ga continental magmatism, sedimentation and metamorphism, Sveconorwegian province, S Norway. Precambr. Res. 124, 215-241.

Bingen, B., Davis, W.J., Hamilton, M.A., Engvik, A., Stein, H.J., Skår, Ø., Nordgulen, Ø., 2008b. Geochronology of high-grade metamorphism in the Sveconorwegian belt, $S$ Norway: U-Pb, Th-Pb and Re-Os data. Norw. J. Geol. 88, 13-42.

Bingen, B., Corfu, F., Stein, H.J., Whitehouse, M.J., 2015. U-Pb geochronology of the synorogenic Knaben molybdenum deposits, Sveconorwegian orogen, Norway. Geol. Mag. 152, 537-556.

Bingen, B., Viola, G., Yi, K., Engvik, A., 2014. Abstract. The case for a mid-crustal channel flow during the Sveconorwegian orogeny? In: 31st Nordic Geological Winter Meeting, Lund, Sweden, January 8-10 pp. 105.

Bird, P., 1979. Continental delamination and the Colorado Plateau. J. Geophys. Res. Solid Earth 84 (B13), 7561-7571.

Blereau, E., Johnson, T.E., Clark, C., Taylor, R.J.M., Kinny, P.D., Hand, M., 2017. Reappraising the P-T evolution of the Rogaland-Vest Agder Sector, southwestern Norway. Geosci. Front. 8, 1-14.

Bogdanova, S., Bingen, B., Gorbatschev, R., Kheraskova, T., Kozlov, V., Puchkov, V., Volozh, Y., 2008. The East European Craton (Baltica) before and during the assembly of Rodinia. Precambr. Res. 160, 23-45.

Bolle, O., et al., 2018. Pluton construction and deformation in the Sveconorwegian crust of SW Norway: magnetic fabric and U-Pb geochronology of the Kleivan and Sjelset

granitic complexes. Precambr. Res. 305, 247-267.

Bouvier, A., Vervoort, J.D., Patchett, P.J., 2008. The Lu-Hf and Sm-Nd isotopic composition of CHUR: constraints from unequilibrated chondrites and implications for the bulk composition of terrestrial planets. Earth Planet. Sci. Lett. 273, 48-57.

Brander, L., Söderlund, U., 2009. Mesoproterozoic (1.47-1.44 Ga) orogenic magmatism in Fennoscandia; baddeleyite $\mathrm{U}-\mathrm{Pb}$ dating of a suite of massif-type anorthosite in $\mathrm{S}$ Sweden. Int. J. Earth Sci. 98, 499-516.

Brewer, T.S., Daly, J.S., Åhäll, K.I., 1998. Contrasting magmatic arcs in the

Palaeoproterozoic of the south-western Baltic Shield. Precambr. Res. 92, 297-315. Brewer, T.S., Åhäll, K.I., Darbyshire, D.P.F., Menuge, J.F., 2002. Geochemistry of late Mesoproterozoic volcanism in southwestern Scandinavia: implications for Sveconorwegian/Grenvillian plate tectonic models. J. Geol. Soc. London 159, 129-144.

Brewer, T.S., Åhäll, K.I., Menuge, J.F., Storey, C.D., Parrish, R.R., 2004. Mesoproterozoic bimodal volcanism in SW Norway, evidence for recurring pre-Sveconorwegian continental margin tectonism. Precambr. Res. 134, 249-273.

Broekmans, M.A., Nijland, T.G., Jansen, J.B.H., 1994. Are stable isotopic trends in amphibolite to granulite facies transitions metamorphic of diagenetic? - an answer for the Arendal area (Bamble sector, S.E. Norway) from mid-Proterozoic carbon bearing rocks. Am. J. Sci. 294, 1135-1165.

Bugge, A., 1936. Kongsberg-Bamble formasjonen. Nor. Geol. Unders. 146, 1-117.

Cameron, K.L., Lopez, R., Ortega-Gutiérrez, F.L.S.A., Keppie, J.D., Schulze, C., 2004. U-Pb geochronology and $\mathrm{Pb}$ isotopic compositions of leached feldspars: constraints on the origin and evolution of Grenville rocks from eastern and southern Mexico. Geol. Soc. Am. Memoirs 197, 755-769.

Carr, S.D., Easton, R.M., Jamieson, R.A., Culshaw, N.G., 2000. Geologic transect across the Grenville orogen of Ontario and New York. Can. J. Earth Sci. 37, 193-216. Cawood, P.A., Hawkesworth, C.J., Dhuime, B., 2013. The continental record and the generation of continental crust. Geol. Soc. Am. Bull. 125, 14-32.

Cawood, P.A., Pisarevsky, S.A., 2017. Laurentia-Baltica-Amazonia relations during Rodinia assembly. Precambr. Res. 292, 386-397.

Cecys, A., Benn, K., 2007. Emplacement and deformation of the ca. 1.45 Ga Karlshamn granitoid pluton, southeastern Sweden, during ENE-WSW Danopolonian shortening. Int. J. Earth Sci. 96, 397-414.

Chen, M., Niu, F., Tromp, J., Lenardic, A., Lee, C.T.A., Cao, W., Ribeiro, J., 2017. Lithospheric foundering and underthrusting imaged beneath Tibet. Nat. Commun. 8, 15659.

Clough, P.W., Field, D., 1980. Chemical variation in metabasites from a Proterozoic amphibolite-granulite transition zone, S Norway. Contrib. Miner. Petrol. 73, 277-286.

Coint, N., Slagstad, T., Roberts, N.M.W., Marker, M., Røhr, T., Sørensen, B.E., 2015. The Late Mesoproterozoic Sirdal Magmatic Belt, SW Norway: relationships between magmatism and metamorphism and implications for Sveconorwegian orogenesis. Precambr. Res. 265, 57-77.

Connelly, J.N., Åhäll, K.I., 1996. The Mesoproterozoic cratonization of Baltica - new age constraints from SW Sweden. In: Brewer, T.S. (Ed.), Precambrian Crustal Evolution in the North Atlantic Region. Geological Society, London, pp. 261-273 Special Publications.

Cooper, D.C., Field, D., 1977. The chemistry and origins of Proterozoic low-potash, highiron, charnockitic gneisses from Tromøy, South Norway. Earth Planet. Sci. Lett. 35,

$105-115$

Corfu, F., Laajoki, K., 2008. An uncommon episode of mafic magmatism at $1347 \mathrm{Ma}$ in the Mesoproterozoic Telemark supracrustals, Sveconorwegian orogen - implications for stratigraphy and tectonic evolution. Precambr. Res. 160, 299-307.

Corrigan, D., Hanmer, S., 1997. Anorthosites and related granitoids in the Grenville orogen: a product of convective thinning of the lithosphere? Geology 25, 61-64.

Corriveau, L., van Breemen, O., 2000. Docking of the Central Metasedimentary Belt to Laurentia in geon 12: evidence from the 1.17-1.16 Chevreuil intrusive suite and host gneisses, Quebec. Can. J. Earth Sci. 37, 253-269.

Cosca, M.A., Mezger, K., Essene, E.J., 1998. The Baltica-Laurentia connection: Sveconorwegian (Grenvillian) metamorphism, cooling, and unroofing in the Bamble Sector, Norway. J. Geol. 106, 539-552.

Cosca, M.A., O'Nions, R.K., 1994. A re-examination of the influence of composition on argon retentivity in metamorphic calcic amphiboles. Chem. Geol. 112, 39-56.

Cosentino, D., et al., 2017. New insights into the onset and evolution of the centra

Apennine extensional intermontane basins based on the tectonically active L'Aquila Basin (central Italy). Geol. Soc. Am. Bull. 129, 1314-1336.

Davidson, A., 2008. Late Paleoproterozoic to mid-Neoproterozoic history of northern Laurentia: an overview of central Rodinia. Precambr. Res. 160, 5-22.

DeCelles, P.G., Robinson, D.M., Zandt, G., 2002. Implications of shortening in the

Himalayan fold-thrust belt for uplift of the Tibetan Plateau. Tectonics 21, 1062. deHaas, G.J.L.M., Andersen, T., Vestin, J., 1999. Detrital zircon geochronology: new evidence for an old model for accretion of the SW Baltic Shield. J. Geol. 107, 569-586.

deHaas, G.J.L.M., Nijland, T.G., Andersen, T., Corfu, F., 2002a. New constraints on the timing of deposition and metamorphism in the Bamble sector, south Norway: zircon and titanite U-Pb data from the Nelaug area. Geol. Foeren. Stockholm Foerh. 124, 73-78.

deHaas, G.J.L.M., Nijland, T.G., Valbracht, P.J., Maijer, C., Verschure, R., Andersen, T., 2002b. Magmatic versus metamorphic origin of olivine-plagioclase coronas. Contrib. Miner. Petrol. 143, 537-550.

Demaiffe, D., Michot, J., 1985. Isotope geochronology of the Proterozoic crustal segment of southern Norway: a review. In: Tobi, A.C., Touret, J.L. (Eds.), The Deep

Proterozoic Crust in the North Atlantic Provinces. NATO ASI Series Reidel, Dordrecht, pp. 411-433.

Dewey, J.F., 1988. Extensional collapse of orogens. Tectonics 7, 1123-1139.

Dhuime, B., Hawkesworth, C., Cawood, P., 2011. When continents formed. Science 331, 154-155.

Dons, J.A., 1960a. The Stratigraphy of Supracrustal Rocks, Granitization and Tectonics in the Precambrian Telemark Area, Southern Norway. Norges geologiske undersøkelse, pp. 1-30.

Dons, J.A., 1960b. Telemark supracrustals and associated rocks. In: Holtedahl, O. (Ed.), Geology of Norway. Norges geologiske undersøkelse, pp. 49-58.

Dons, J.A., Jorde, K., 1978. Geologisk kart over Norge, berggrunnskart Skien, 1:250000. Norges geologiske undersøkelse.

Drüppel, K., Elsässer, L., Brandt, S., Gerdes, A., 2013. Sveconorwegian mid-crustal ultrahigh-temperature metamorphism in Rogaland, Norway: U-Pb LA-ICP-MS geochronology and pseudosections of sapphirine granulites and associated paragneisses. J. Petrol. 54, 305-350.

England, P., Houseman, G., 1989. Extension during continental convergence, with application to the Tibetan Plateau. J. Geophys. Res. Solid Earth 94, 17561-17579.

Engvik, A.K., et al., 2011. Metasomatism of gabbro - mineral replacement and element mobilization during the Sveconorwegian metamorphic event. J. Metamorph. Geol. 29, 399-423.

Engvik, A.K., Ihlen, P.M., Austrheim, H., 2014. Characterisation of Na-metasomatism in the Sveconorwegian Bamble Sector of South Norway. Geosci. Front. 5, 659-672.

Engvik, A.K., Bingen, B., Solli, A., 2016. Localized occurrences of granulite: P-T modeling, $\mathrm{U}-\mathrm{Pb}$ geochronology and distribution of early-Sveconorwegian high-grade metamorphism in Bamble, South Norway. Lithos 240-243, 84-103.

Engvik, A.K., Corfu, F., Solli, A., Austrheim, H., 2017. Sequence and timing of mineral replacement reactions during albitisation in the high-grade Bamble lithotectonic domain, S-Norway. Precambr. Res. 291, 1-16.

Falkum, T., 1985. Geotectonic evolution of southern Scandinavia in light of a lateProterozoic plate-collision. In: Tobi, A.C., Touret, J.L. (Eds.), The Deep Proterozoic crust in the north Atlantic provinces. NATO ASI Series Reidel, Dordrecht, pp. 309322.

Field, D., Drury, S.A., Cooper, D.C., 1980. Rare-earth and LIL element fractionation in high-grade charnockitic gneisses, south Norway. Lithos 13, 281-289.

Field, D., Smalley, P.C., Lamb, R.C., Råheim, A., 1985. Geochemical evolution of the 1.6 1.5 Ga-old amphibolite-granulite facies terrain, Bamble sector, Norway: dispelling the myth of grenvillian high-grade reworking. In: Tobi, A.C., Touret, J.L. (Eds.), The Deep Proterozoic Crust in the North Atlantic Provinces. NATO ASI Series , Reidel, Dordrecht, pp. 567-578.

Gammon, J.B., 1966. Fahlbands in the Precambrian of southern Norway. Econ. Geol. 61, 174-188.

Göğüş, O.H., 2015. Rifting and subsidence following lithospheric removal in continental back arcs. Geology 43, 3-6.

Gögüs, O.H., Pysklywec, R.N., 2008. Near-surface diagnostics of dripping or delaminating lithosphere. J. Geophys. Res. Solid Earth 113.

Gorczyk, W., Hobbs, B., Gessner, K., Gerya, T., 2013. Intracratonic geodynamics. Gondwana Res. 24, 838-848.

Gower, C.F., Kamo, S., Krogh, T.E., 2008. Indentor tectonism in the eastern Grenville Province. Precambr. Res. 167, 201-212.

Graversen, O., Pedersen, S., 1999. Timing of Gothian structural evolution in SE Norway: a Rb-Sr whole-rock age study. Nor. Geol. Tidsskr. 79, 47-56.

Gray, R., Pysklywec, R.N., 2012. Geodynamic models of mature continental collision: evolution of an orogen from lithospheric subduction to continental retreat/delamination. J. Geophys. Res. Solid Earth 117, B03408.

Griffin, W.L., Pearson, N.J., Belousova, E.A., Jackson, S.E., van Achterbergh, E., O'Reilly, S.Y., Shee, S.R., 2000. The Hf isotope composition of cratonic mantle: LAM-MCICPMS analysis of zircon megacrysts in kimberlites. Geochim. Cosmochim. Acta 64, 133-147.

Griffin, W.L., O'Reilly, S.Y., Afonso, J.C., Begg, G.C., 2009. The composition and evolution 
of lithospheric mantle: a re-evaluation and its tectonic implications. J. Petrol. 50, 1185-1204.

Hansen, B.T., Persson, P.O., Söllner, F., Lindh, A., 1989. The influence of recent lead loss on the interpretation of disturbed U-Pb systems in zircons from metamorphic rocks in southwest Sweden. Lithos 23, 123-136.

Harley, S., Kelly, N.M., Möller, A., 2007. Zircon behaviour and the thermal histories of mountain chains. Elements 3, 25-30.

Harlov, D.E., 2000. Pressure-temperature estimation in orthopyroxene-garnet bearing granulite facies rocks, Bamble Sector, Norway. Mineral. Petrol. 69, 11-33.

Hartz, E.H., Torsvik, T.H., 2002. Baltica upside down: a new plate tectonic model for Rodinia and the Iapetus Ocean. Geology 30, 255-258.

Heaman, L.M., Smalley, P.C., 1994. A U-Pb study of the Morkheia Complex and associated gneisses, south Norway: implications for disturbed $\mathrm{Rb}-\mathrm{Sr}$ systems and for the temporal evolution of Mesoproterozoic magmatism in Laurentia. Geochim. Cosmochim. Acta 58, 1899-1911.

Hellström, F.A., Johansson, ̊̊., Larson, S.Å., 2004. Age emplacement of late Sveconorwegian monzogabbroic dykes, SW Sweden. Precambr. Res. 128, 39-55.

Henderson, I.H.C., Ihlen, P.M., 2004. Emplacement of polygeneration pegmatites in re lation to Sveconorwegian contractional tectonics: examples from southern Norway.

Precambr. Res. 133, 207-222.

Hoffman, P.F., 1991. Did the breakout of Laurentia turn Gondwanaland inside-out? Science 252, 1409-1412.

Högdahl, K., Andersson, U.B., Eklund, O., 2004. The Transcandinavian Igneous Belt (TIB) in Sweden: A Review of its Character and Evolution, 37. Geological Survey of Finland, pp. 37 Special Paper.

Hynes, A., Rivers, T., 2010. Protracted continental collision - evidence from the Grenville Orogen. Can. J. Earth Sci. 47, 591-620.

Ibanez-Mejia, M., et al., 2015. Unraveling crustal growth and reworking processes in complex zircons from orogenic lower-crust: the Proterozoic Putumayo Orogen of Amazonia. Precambr. Res. 267, 285-310.

Ibanez-Mejia, M., Ruiz, J., Valencia, V.A., Cardona, A., Gehrels, G.E., Mora, A.R., 2011. The Putumayo Orogen of Amazonia and its implications for Rodinia reconstructions: new U-Pb geochronological insights into the Proterozoic tectonic evolution of northwestern South America. Precambr. Res. 191, 58-77.

Indares, A., Dunning, G.R., 2004. Crustal architecture above the high-pressure belt of the Grenville Province in the Manicouagan area: new structural, petrologic and U-Pb age constraints. Precambr. Res. 130, 199-228.

INSPIRE Directive, 2007. INSPIRE Knowledge Base, Infrastructure for spatial information in Europe, registry. European Commission;

Jacobsen, S.B., Heier, K.S., 1978. Rb-Sr isotope systematics in metamorphic rocks, Kongsberg sector, S Norway. Lithos 11, 257-276.

Jamieson, R.A., Beaumont, C., Nguyen, N.H., Culshaw, N.G., 2007. Synconvergent ductile flow in variable-strength continental crust: numerical models with application to the western Grenville orogen. Tectonics 26, TC5005.

Jeon, H., Whitehouse, M.J., 2015. A critical evaluation of U-Pb calibration schemes used in SIMS zircon geochronology. Geostand. Geoanal. Res. 39, 443-452.

Johansson, A., 2009. Baltica, Amazonia and the SAMBA connection - 1000 million years of neighbourhood during the Proterozoic? Precambr. Res. 175, 221-234.

Keppie, J.D., Ortega-Gutiérrez, F., 2010. 1.3-0.9 Ga Oaxaquia (Mexico): remnant of an arc/backarc on the northern margin of Amazonia. J. South Am. Earth Sci. 29, 21-27.

Knudsen, T.L., 1996. Petrology and geothermobarometry of granulite facies metapelites from the Hisøy-Torungen area, south Norway: new data on the Sveconorwegian P-T-t path of the Bamble sector. J. Metamorph. Geol. 14, 267-287.

Knudsen, T.L., Andersen, T., 1999. Petrology and geochemistry of the Tromøy gneiss complex, South Norway, an alleged example of Proterozoic depleted lower continental crust. J. Petrol. 40, 909-933.

Knudsen, T.L., Andersen, T., Whitehouse, M.J., Vestin, J., 1997. Detrital zircon ages from southern Norway - implications for the Proterozoic evolution of the southwestern

Baltic Shield. Contrib. Miner. Petrol. 130, 47-58.

Koistinen, T., Stephens, M.B., Bogatchev, V., Nordgulen, Ø., Wennerström, M., Korhonen, J., 2001. Geological Map of the Fennoscandian Shield, Scale 1:2000000. Geological Surveys of Finland, Norway and Sweden and the North-West Department of Natural Resources of Russia.

Köykkä, J., 2011. The sedimentation and paleohydrology of the Mesoproterozoic stream deposits in a strike-slip basin (Svinsaga Formation), Telemark, southern Norway. Sed. Geol. 236, 239-255.

Köykkä, J., Laajoki, K., 2009. Mesoproterozoic frost action at the base of the Svinsaga Formation, central Telemark, South Norway. Norw. J. Geol. 89, 291-303. Köykkä, J.,

Lamminen, J., 2011. Tidally influenced clastic epeiric sea at a Mesoproterozoic continental margin, Rjukan Rift Basin, southern Norway. Precambr.

Res. 185, 164-182.

Kullerud, L., Dahlgren, S.H., 1993. Sm-Nd geochronology of Sveconorwegian granulite facies mineral assemblages in the Bamble shear belt, south Norway. Precambr. Res. 64, 389-402.

Kullerud, L., Machado, N., 1991. Abstract. End of a controversy: U-Pb geochronological evidence for significant Grenvillian activity in the Bamble area, Norway. Terra Abstracts, supplement to. Terra 3, 504

Kusebauch, C., John, T., Barnes, J.D., Klügel, A., Austrheim, H.O., 2015. Halogen element and stable chlorine isotope fractionation caused by fluid-rock interaction (Bamble Sector, SE Norway). J. Petrol. 56, 299-324.

Laajoki, K., 2002. The Mesoproterozoic sub-Heddal unconformity, Sauland, central Telemark, Norway. Norw. J. Geol. 82, 139-152.

Laajoki, K., Corfu, F., 2007. Lithostratigraphy of the Mesoproterozoic Vemork formation, central Telemark, Norway. Bull. Geol. Soc. Finland 79, 41-67.

Laajoki, K., Corfu, F., Andersen, T., 2002. Lithostratigraphy and U-Pb geochronology of the Telemark supracrustals in the Bandak-Sauland area, Telemark, South Norway.

Norw. J. Geol. 82, 119-138.

Lamb, R.C., Smalley, P.C., Field, D., 1986. P-T conditions for the Arendal granulites, southern Norway: implications for the roles of $\mathrm{P}, \mathrm{T}$ and $\mathrm{CO} 2$ in deep crustal LILEdepletion. J. Metamorph. Geol. 4, 143-160.
Lamminen, J., 2011. Provenance and correlation of sediments in Telemark, South Norway: status of the Lifjell Group and implications for early Sveconorwegian fault tectonics. Norw. J. Geol. 91, 57-75.

Lamminen, J., Andersen, T., Nystuen, J.P., 2011. Zircon U-Pb ages and Lu-Hf isotopes from basement rocks associated with Neoproterozoic sedimentary successions in the Sparagmite Region and adjacent areas, South Norway: the crustal architecture of western Baltica. Norw. J. Geol. 91, 35-55.

Lamminen, J., Köykkä, J., 2010. The provenance and evolution of the Rjukan Rift Basin, Telemark, south Norway: the shift from a rift basin to an epicontinental sea along a Mesoproterozoic supercontinent. Precambr. Res. 181, 129-149.

Larsen, B.T., Olaussen, S., Sundvoll, B., Heeremans, M., 2008. The Permo-Carboniferous Olso Rift through six stages and 65 million years. Episodes 31, 52-58.

Laurent, A.T., Seydoux-Guillaume, A.M., Duchene, S., Bingen, B., Bosse, V., Datas, L., 2016. Sulphate incorporation in monazite lattice and dating the cycle of sulphur in metamorphic belts. Contrib. Miner. Petrol. 171, 1-19.

Laurent, A.T., Bingen, B., Duchene, S., Whitehouse, M.J., Seydoux-Guillaume, A.M., Bosse, V., 2018. Decoding protracted zircon geochronological record in ultra-high temperature granulite, and persistence of partial melting in the crust, Rogaland, Norway. Contrib. Mineral. Petrol. 173 (29), 25.

Li, Z.X., et al., 2008. Assembly, configuration, and break-up history of Rodinia: a synthesis. Precambr. Res. 160, 179-210.

Lundmark, A.M., Lamminen, J., 2016. The provenance and setting of the Mesoproterozoic Dala Sandstone, western Sweden, and paleogeographic implications for southwestern Fennoscandia. Precambr. Res. 275, 197-208.

Martignole, J., Calvert, A.J., Friedman, R., Reynolds, P., 2000. Crustal evolution along a seismic section across the Grenville Province (western Quebec). Can. J. Earth Sci. 37, 291-306.

Milne, K.P., Starmer, I.C., 1982. Extreme differentiation in the Proterozoic GjerstadMorkeheia complex of South Norway. Contrib. Miner. Petrol. 79, 381-393.

Möller, C., Andersson, J., 2018. Metamorphic zoning and behaviour of an underthrusting continental plate. J. Metamorph. Geol. 1-23 in press.

Möller, C., Andersson, J., Lundqvist, I., Hellström, F.A., 2007. Linking deformation, migmatite formation and zircon U-Pb geochronology in polymetamorphic gneisses,

Sveconorwegian province, Sweden. J. Metamorph. Geol. 25, 727-750.

Möller, C., Andersson, J., Dyck, B., Antal Lundin, I., 2015. Exhumation of an eclogite terrane as a hot migmatitic nappe, Sveconorwegian orogen. Lithos 226, 147-168.

Möller, A., O'Brien, P.J., Kennedy, A., Kröner, A., 2002. Polyphase zircon in ultrahightemperature granulites (Rogaland, SW Norway): constraints for $\mathrm{Pb}$ diffusion in zircon. J. Metamorph. Geol. 20, 727-740.

Möller, A., O'Brien, P.J., Kennedy, A., Kröner, A., 2003. Linking growth episodes of zircon and metamorphic textures to zircon chemistry: an example from the ultrahigh-temperature granulites of Rogaland (SW Norway). In: Vance, D., Müller, W., Villa, I.M. (Eds.), Geochronology: Linking the Isotopic Record with Petrology and Textures. Geological Society, London, pp. 65-81 Special Publications.

Molnar, P., England, P.C., Jones, C.H., 2015. Mantle dynamics, isostasy, and the support of high terrain. J. Geophys. Res. Solid Earth 120, 1932-1957.

Morton, R.D., 1971. Geological investigations in the Bamble sector of the Fennoscandian Shield, S. Norway. No II. Metasediments and metapyroclastics (?) within the Precambrian metamorphic suite of the S Norwegian Skaergaard. Nor. Geol. Tidsskr. $51,63-83$.

Mulch, A., Cosca, M.A., Andresen, A., Fiebig, J., 2005. Time scales of deformation and exhumation in extensional detachment systems determined by high-spatial resolution in situ UV-laser ${ }^{40} \mathrm{Ar} /{ }^{39} \mathrm{Ar}$ dating. Earth Planet. Sci. Lett. 233, 375-390.

Müller, A., Romer, R.L., Pedersen, R.B., 2017. The Sveconorwegian Pegmatite Province thousands of pegmatites without parental granite. Can. Mineral. 55, 283-315.

Munz, I.A., 1990. Whiteschists and orthoamphibole-cordierite rocks and the P-T-t path of the Modum Complex, South Norway. Lithos 24, 181-200.

Munz, I.A., Morvik, R., 1991. Metagabbros in the Modum Complex, southern Norway: an important heat source for Sveconorwegian metamorphism. Precambr. Res. 52, 97-113.

Munz, I.A., Wayne, D., Austrheim, H., 1994. Retrograde fluid infiltration in the highgrade Modum Complex, South Norway - evidence for age, source and REE mobility. Contrib. Miner. Petrol. 116, 32-46.

Nijland, T.G., Harlov, D.E., Andersen, T., 2014. The Bamble Sector, South Norway: a review. Geosci. Front. 5, 635-658.

Nijland, T.G., Maijer, C., 1993. The regional amphibolite to granulite facies transition at Arendal, Norway: evidence for a thermal dome. Neues Jahrb. Mineral. Abh. 165, 191-221.

Nijland, T.G., Maijer, C., Senior, A., Verschure, R.H., 1993. Primary sedimentary structures and compositions of the high-grade metamorphic Nidelva Quartzite Complex (Bamble, Norway), and the origin of nodular gneisses. Proc. K. Ned. Akad. Wet. 96, 217-232.

Nijland, T.G., Senior, A., 1991. Sveconorwegian granulite facies metamorphism of polyphase migmatites and basic dikes, South Norway. J. Geol. 99, 515-525.

Nijland, T.G., Touret, J.L.R., Visser, D., 1998. Anomalously low temperature orthopyroxene, spinel, and sapphirine occurrences in metasediments from the Bamble amphibolite-to-granulite facies transition zone (South Norway): possible evidence for localized action of saline fluids. J. Geol. 106, 575-590.

Padget, P., Brekke, H., 1996. Geologisk kart over Norge, berggrunnskart Arendal, $1: 250000$. Nor. Geol. Unders.

Park, R.G., Åhäll, K.I., Boland, M.P., 1991. The Sveconorwegian shear-zone network of SW Sweden in relation to mid-Proterozoic plate movements. Precambr. Res. 49, 245-260.

Pedersen, S., Andersen, T., Konnerup-Madsen, J., Griffin, W.L., 2009. Recurrent Mesoproterozoic continental magmatism in South-Central Norway. Int. J. Earth Sci. 98, 1151-1171.

Petersson, A., Scherstén, A., Bingen, B., Gerdes, A., Whitehouse, M.J., 2015b. Mesoproterozoic continental growth: U-Pb-Hf-O zircon record in the Idefjorden Terrane, Sveconorwegian Orogen. Precambr. Res. 261, 75-95.

Petersson, A., Scherstén, A., Andersson, J., Möller, C., 2015a. Zircon U-Pb and Hf isotopes 
from the eastern part of the Sveconorwegian Orogen, SW Sweden: implications for the growth of Fennoscandia. Special Publications In: Roberts, N.M.W., van Kranendonk, M., Parman, S., Shirey, S., Clift, P.D. (Eds.), Continent Formation through Time. Geological Society, London, pp. 281-303.

Pidgeon, R.T., Nemchin, A.A., Kinny, P.D., 2000. Abstract. Fir-tree and nebulously zoned zircons from granulite facies rocks: evidence for zircon growth and interaction with metamorphic fluids, Journal of Conference Abstracts, Goldschmidt 2000, September 3rd-8th, 2000, Oxford, UK, pp. 798.

Piñán-Llamas, A., Andersson, J., Möller, C., Johansson, L., Hansen, E., 2015. Polyphasal foreland-vergent deformation in a deep section of the $1 \mathrm{Ga}$ Sveconorwegian orogen.

Precambr. Res. 265, 121-149.

Pisarevsky, S.A., Elming, S.Å., Pesonen, L.J., Li, Z.X., 2014. Mesoproterozoic paleogeography: supercontinent and beyond. Precambr. Res. 244, 207-225. Poudjom Djomani, Y.H., O'Reilly, S.Y., Griffin, W.L., Morgan, P., 2001. The density structure of subcontinental lithosphere through time. Earth Planet. Sci. Lett. 184,

605-621.

Raimondo, T., Hand, M., Collins, W.J., 2014. Compressional intracontinental orogens: ancient and modern perspectives. Earth Sci. Rev. 130, 128-153.

Rivers, T., 2008. Assembly and preservation of lower, mid, and upper orogenic crust in the Grenville Province-Implications for the evolution of large hot long-duration orogens. Precambr. Res. 167, 237-259.

Rivers, T., 2009. The Grenville Province as a large hot long-duration collisional orogen insights from the spatial and thermal evolution of its orogenic fronts. Special Publications In: Murphy, J.B., Keppie, J.D., Hynes, A.J. (Eds.), Ancient Orogens and Modern Analogues. Geological Society, London, pp. 405-444.

Roberts, N.M.W., Slagstad, T., 2015. Continental growth and reworking on the edge of the Columbia and Rodinia supercontinents; $1.86-0.9$ Ga accretionary orogeny in southwest Fennoscandia. Int. Geol. Rev. 57, 1582-1606.

Roberts, N.M.W., Slagstad, T., Parrish, R.R., Norry, M.J., Marker, M., Horstwood, M.S.A., 2013. Sedimentary recycling in arc magmas: geochemical and U-Pb-Hf-O constraints on the Mesoproterozoic Suldal Arc, SW Norway. Contrib. Miner. Petrol. 165, 507523.

Royden, L.H., 1993. Evolution of retreating subduction boundaries formed during continental collision. Tectonics 12, 629-638.

Rubatto, D., Williams, I.S., Buick, I.S., 2001. Zircon and monazite response to prograde metamorphism in the Reynolds Range, central Australia. Contrib. Miner. Petrol. 140, 458-468.

Rudnick, R.L., Presper, T., 1990. Geochemistry of intermediate- to high-pressure granulites. In: Vielzeuf, D., Vidal, P. (Eds.), Granulites and Crustal Evolution. NATO ASI Series Kluwer Academic, Norwell, pp. 523-550.

Scheiber, T., Viola, G., Bingen, B., Peters, M., Solli, A., 2015. Multiple reactivation and strain localization along a Proterozoic orogen-scale deformation zone: the Kongsberg-

Telemark boundary in southern Norway revisited. Precambr. Res. 265, 78-103. Scherer,

E., Munker, C., Mezger, K., 2001. Calibration of the lutetium-hafnium clock. Science 293, 683-687.

Sigmond, E.M.O., 1975. Geologisk kart over Norge, berggrunnskart Sauda, 1:250000 Norges geologiske undersøkelse, Trondheim.

Sigmond, E.M.O., 1978. Beskrivelse til det berggrunnsgeologiske kartbladet Sauda 1:250000. Norges geologiske undersøkelse Bulletin, pp. 1-94.

Slagstad, T., et al., 2018. Magma-driven, high-grade metamorphism in the Sveconorwegian Province, southwest Norway, during the terminal stages of Fennoscandian Shield evolution. Geosphere 14, 1-22.

Slagstad, T., Roberts, N.M.W., Marker, M., Røhr, T.S., Schiellerup, H., 2013. A non-collisional, accretionary Sveconorwegian orogen. Terra Nova 25, 30-37.

Slagstad, T., Roberts, N.M.W., Kulakov, E., 2017. Linking orogenesis across a supercontinent; the Grenvillian and Sveconorwegian margins on Rodinia. Gondwana Res.

44, 109-115.

Söderlund, U., Jarl, L.G., Persson, P.O., Stephens, M.B., Wahlgren, C.H., 1999. Protolith ages and timing of deformation in the eastern, marginal part of the Sveconorwegian orogen, southwestern Sweden. Precambr. Res. 94, 29-48.

Söderlund, U., Hellström, F.A., Kamo, S.L., 2008. Geochronology of high-pressure mafic granulite dykes in SW Sweden; tracking the P-T-t path of metamorphism using Hf

isotopes in zircon and baddeleyite. J. Metamorph. Geol. 26, 539-560.

Spencer, C.J., Roberts, N.M.W., Cawood, P.A., Hawkesworth, C.J., Prave, A.R., Antonini, A.S.M., Horstwood, M.S.A., 2014. Intermontane basins and bimodal volcanism at the onset of the Sveconorwegian Orogeny, southern Norway. Precambr. Res. 252, 107118.

Starmer, I.C., 1985. The evolution of the south Norwegian Proterozoic as revealed by the major and mega-tectonics of the Kongsberg and Bamble sector. In: Tobi, A.C., Touret, J.L. (Eds.), The Deep Proterozoic Crust in the North Altantic Provinces. NATO ASI Series Reidel, Dordrecht, pp. 259-290.

Starmer, I.C., 1991. The Proterozoic evolution of the Bamble sector shear belt, southern Norway: correlations across southern Scandinavia and the Grenvillian controversy. Precambr. Res. 49, 107-139.

Stein, H.J., Bingen, B., 2002. 1.05-1.01 Ga Sveconorwegian metamorphism and deformation of the supracrustal sequence at Sæsvatn, South Norway: Re-Os dating of Cu-Mo mineral occurrences. In: Blundell, D., Neubauer, F., von Quadt, A. (Eds.), The
Timing and Location of Major Ore Deposits in an Evolving Orogen. Geological Society, London, pp. 319-335 Special Publications.

Tobi, A.C., Hermans, G.A., Maijer, C., Jansen, J.B.H., 1985. Metamorphic zoning in the high-grade Proterozoic of Rogaland-Vest Agder, SW Norway. In: Tobi, A.C., Touret, J.L. (Eds.), The deep Proterozoic Crust in the North Atlantic Provinces. NATO ASI Series Reidel, Dordrecht, pp. 477-497.

Tohver, E., van der Pluijm, B.A., Van der Voo, R., Rizzotto, G., Scandolara, J.E., 2002 Paleogeography of the Amazon craton at $1.2 \mathrm{Ga}$ : early Grenvillian collision with the Llano segment of Laurentia. Earth Planet. Sci. Lett. 199, 185-200.

Tohver, E., Bettencourt, J.S., Tosdal, R., Mezger, K., Leite, W.B., Payolla, B.L., 2004 Terrane transfer during the Grenville orogeny: tracing the Amazonian ancestry of southern Appalachian basement through $\mathrm{Pb}$ and Nd isotopes. Earth Planet. Sci. Lett. 228, 161-176.

Tohver, E., van der Pluijm, B.A., Scandolara, J.E., Essene, E., 2005. Late Mesoproterozoic deformation of SW Amazonia (Rondônia, Brazil): geochronological and structural evidence for collision with southern Laurentia. J. Geol. 113, 309-323.

Touret, J.L., 1967. Les gneiss oeillés de la région de Vegarshei-Gjerstad (Norvège méridionale): étude pétrographique. Nor. Geol. Tidsskr. 47, 131-148. Touret, J.L., 1971a. Le facies granulite en Norvège méridionale. 1. Les associations minéralogiques. Lithos 4, 239-249.

Touret, J.L., 1971b. Le facies granulite en Norvège méridionale. 2. Les inclusions fluides. Lithos 4, 423-436.

Touret, J.L., 1987. Day 2 - the high-grade metamorphic Bamble sector. Special Publication No 1 In: Maijer, C., Padget, P. (Eds.), The Geology of Southernmost Norway: An Excursion Guide. Norges Geologiske Undersøkelse, pp. 25-30.

Touret, J.L., Falkum, T., 1987. Day 2-Day 3 - the high-grade metamorphic Bamble sector. Special Publication No 1, Trondheim In: Maijer, C., Padget, P. (Eds.), The Geology of Southernmost Norway: An Excursion Guide. Norges geologiske undersøkelse, pp. 22-33.

Ueda, K., Gerya, T., Sobolev, S.V., 2008. Subduction initiation by thermal-chemical plumes: numerical studies. Phys. Earth Planet. Inter. 171, 296-312.

Ulmius, J., Andersson, J., Möller, C., 2015. Hallandian 1.45 Ga high-temperature metamorphism in Baltica: P-T evolution and SIMS U-Pb zircon ages of aluminous gneisses, SW Sweden. Precambr. Res. 265, 10-39.

Vander Auwera, J., et al., 2011. Sveconorwegian massif-type anorthosites and related granitoids result from post-collisional melting of a continental root. Earth Sci. Rev. 107, 375-397.

Vavra, G., Gebauer, D., Schmid, R., Compston, W., 1996. Multiple zircon growth and recrystallization during polyphase Late Carboniferous to Triassic metamorphism in granulites of the Ivrea Zone (Southern Alps): an ion microprobe (SHRIMP) study. Contrib. Miner. Petrol. 122, 337-358.

Vavra, G., Schmid, R., Gebauer, D., 1999. Internal morphology, habit and U-Th-Pb microanalysis of amphibolite-to-granulite facies zircons: geochronology of the Ivrea Zone (Southern Alps). Contrib. Miner. Petrol. 134, 380-404.

Vermeesch, P., 2012. On the visualisation of detrital age distributions. Chem. Geol. 312, 190-194.

Viola, G., Henderson, I.H.C., Bingen, B., Hendriks, B.W.H., 2011. The GrenvillianSveconorwegian orogeny in Fennoscandia: back-thrusting and extensional shearing along the "Mylonite Zone". Precambr. Res. 189, 368-388.

Viola, G., Bingen, B., Solli, A., 2016. Berggrunnskart Kongsberg lithotectoniske enhet, Kongsberg-Modum-Hønefoss, M 1:100000 - Bedrock geology map of the Kongsberg lithotectonic unit, Kongsberg-Modum-Hønefoss, scale 1:100000, 1 sheet. Norges Geologiske Undersøkelse - Geological Survey of Norway pp. Scale 1:100000, 1 sheet.

Wahlgren, C.H., Cruden, A.R., Stephens, M.B., 1994. Kinematics of a major fan-like structure in the eastern part of the Sveconorwegian orogen, Baltic Shield, southcentral Sweden. Precambr. Res. 70, 67-91.

Wahlgren, C.H., Page, L., Kübler, L., Delin, H., 2015. 40Ar-39Ar biotite age of a lamprophyre dyke and constraints on the timing of ductile deformation inside the Idefjorden terrane and along the Mylonite Zone, Sveconorwegian orogen, south-west Sweden. GFF first view, pp. 1-9.

Weber, B., Scherer, E.E., Schulze, C., Valencia, V.A., Montecinos, P., Mezger, K., Ruiz, J., 2010. U-Pb and Lu-Hf isotope systematics of lower crust from central-southern Mexico - geodynamic significance of Oaxaquia in a Rodinia Realm. Precambr. Res. 182, 149-162.

Whitehouse, M.J., Kamber, B.S., 2005. Assigning dates to thin gneissic veins in high-grade metamorphic terranes: a cautionary tale from Akilia, Southwest Greenland. J. Petrol. 46, 291-318.

Whitehouse, M.J., Platt, J.P., 2003. Dating high-grade metamorphism - constraints from rare-earth elements in zircon and garnet. Contrib. Miner. Petrol. 145, 61-74. Wodicka, N., Ketchum, J.W.F., Jamieson, R.A., 2000. Grenvillian metamorphism of monocyclic rocks, Georgian Bay, Ontario, Canada: implications for convergence history. Can. Mineral. 38, 471-510.

Yakymchuk, C., Brown, M., 2014. Behaviour of zircon and monazite during crustal melting. J. Geol. Soc. London 171, 465-479.

Zhao, Z., et al., 2009. Geochemical and Sr-Nd-Pb-O isotopic compositions of the postcollisional ultrapotassic magmatism in SW Tibet: petrogenesis and implications for India intra-continental subduction beneath southern Tibet. Lithos 113, 190-212. 